\title{
PREOPERATIONAL RADIATION SURVEILLANCE \\ OF THE WIPP PROJECT BY EEG \\ FOR THE YEARS 1993 - 1995
}

\author{
Jim W. Kenney \\ Donald H. Gray \\ Sally C. Ballard
}

Environmental Evaluation Group

P. O. Box 3149, 505 North Main Street

Carlsbad, New Mexico 88221

and

7007 Wyoming Boulevard NE, Suite F-2

Albuquerque, New Mexico 87109

March 1998

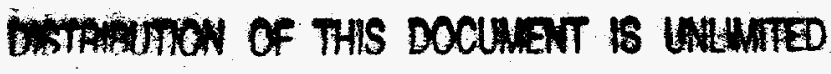

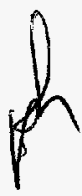




\section{DISCLAIMER}

This report was prepared as an account of work sponsored by an agency of the United States Government. Neither the United States Government nor any agency thereof, nor any of their employees, makes any wartanty, express or implied, or assumes any legal liability or responsibility for the accuracy, completeness, or usefulness of any information, apparatus, product, or process disclosed, or represents that its use would not infringe privately owned rights. Reference herein to any specific commercial product, process, or service by trade name, trademark, manufacturer, or otherwise does not necessarily constitute or imply its endorsement, recommendation, or favoring by the United States Government or any agency thereof. The views and opinions of authors expressed herein do not necessarily state or reflect those of the United States Government or any agency thereof. 


\section{DISCLAIMER}

Portions of this document may be illegible electronic image products. Images are produced from the best available original document. 


\section{FOREWORD}

The purpose of the New Mexico Environmental Evaluation Group (EEG) is to conduct an independent technical evaluation of the Waste Isolation Pilot Plant (WIPP) Project to ensure the protection of the public health and safety and the environment. The WIPP Project, located in southeastern New Mexico, is in the pre-operational phase as a repository for the disposal of transuranic (TRU) radioactive wastes generated by the national defense programs. The EEG was established in 1978 with funds provided by the U. S. Department of Energy (DOE) to the State of New Mexico. Public Law 100-456, the National Defense Authorization Act, Fiscal Year 1989, Section 1433, assigned EEG to the New Mexico Institute of Mining and Technology and continued the original contract DE-AC04-79AL10752 through DOE contract DE-ACO489AL58309. The National Defense Authorization Act for Fiscal Year 1994, Public Law 103160 , continues the authorization.

EEG performs independent technical analyses of the suitability of the proposed site; the design of the repository, its planned operation, and its long-term integrity; suitability and safety of the transportation systems; suitability of the Waste Acceptance Criteria and the generator sites' compliance with them; and related subjects. These analyses include assessments of reports issued by the DOE and its contractors, other federal agencies and organizations, as they relate to the potential health, safety and environmental impacts from WIPP. Another important function of EEG is the independent environmental monitoring of background radioactivity in air, water, and soil, both on-site and off-site.

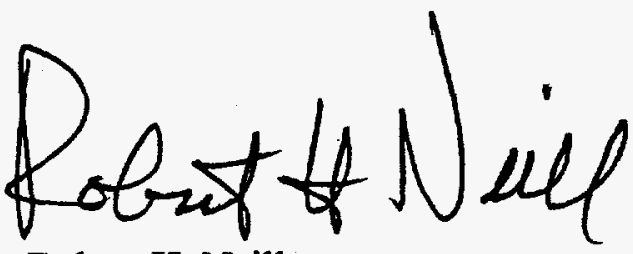

Robert H. Neill

Director 


\section{EEG STAFF}

Sally C. Ballard, B.S., Radiochemist

William T. Bartlett, Ph.D., Health Physicist

Radene Bradley, Secretary III

Lokesh Chaturvedi, Ph.D., Deputy Director \& Engineering Geologist

Patricia D. Fairchild, Secretary III

Donald H. Gray, M.A., Environmental Specialist

Jim W. Kenney, M.S., Environmental Scientist/Supervisor

Lanny King, Assistant Environmental Technician

Betsy J. Kraus, M.S., Technical Editor/Librarian

Robert H. Neill, M.S., Director

Dale Rucker, M.S., Performance Assessment Engineer

Jill Shortencarier, Administrative Secretary

Matthew K. Silva, Ph.D., Chemical Engineer

Susan Stokum, Administrative Secretary

Ben A. Walker, B.A., Quality Assurance Specialist

Brenda J. West, B.A., Administrative Officer 


\section{ACKNOWLEDGMENTS}

The authors wish to express their appreciation to Dr. William Bartlett, Dr. James Channell, Ms. Betsy Kraus, Mr. John Rodgers and Mr. Ben Walker for their helpful review comments. A special thanks to Ms. Susan Stokum for her word processing and careful attention to details during assembly of the report and Mr. Lanny King for his meticulous adherence to procedures during sample collection and sample preparation. 


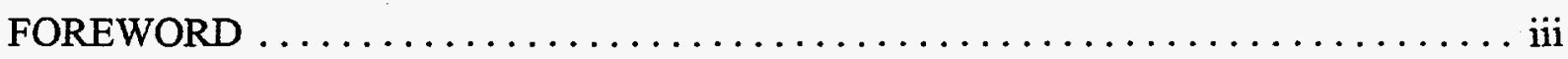

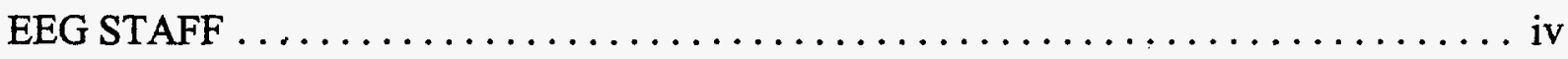

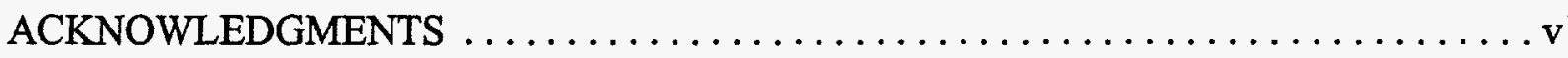

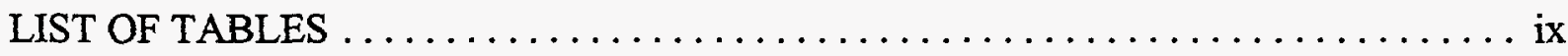

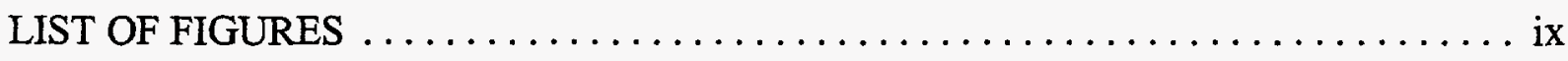

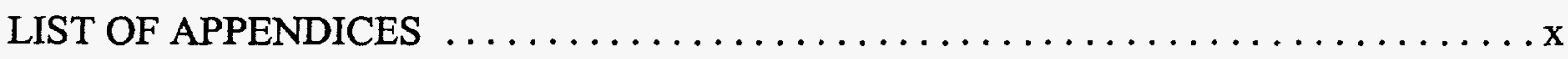

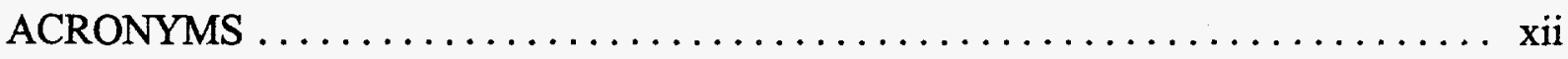

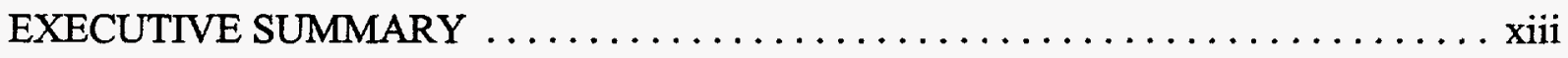

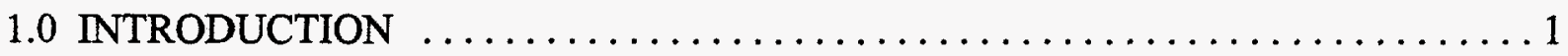

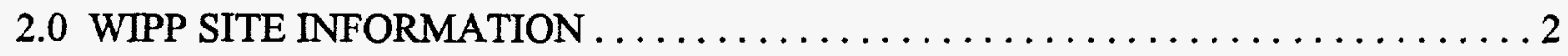

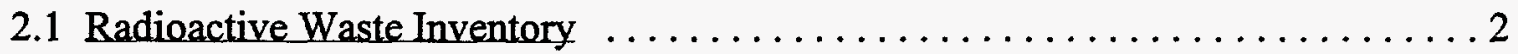

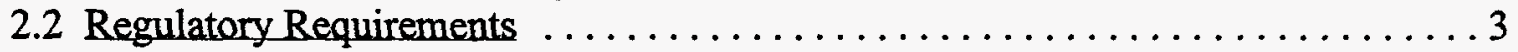

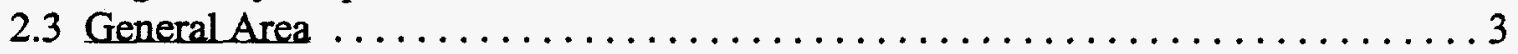

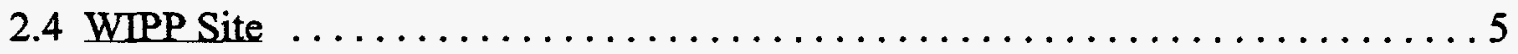

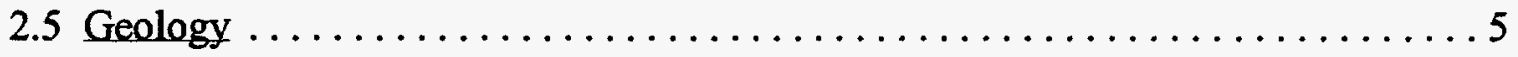

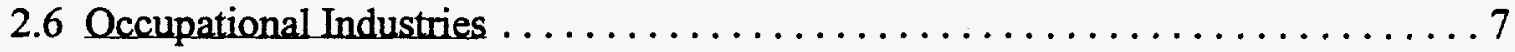

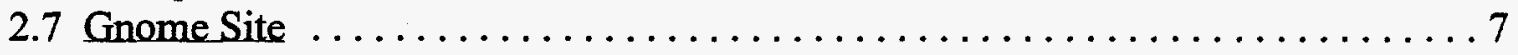

3.0 ENVIRONMENTAL PROGRAM DESCRIPTION $\ldots \ldots \ldots \ldots \ldots \ldots \ldots \ldots$

3.1 Program Overview .................................. 8

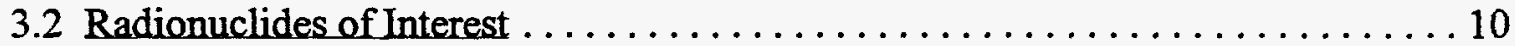

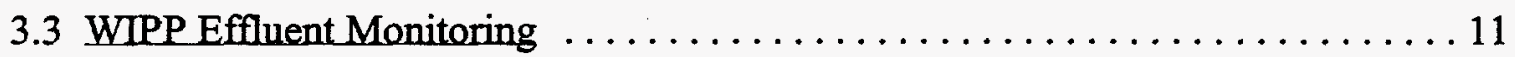

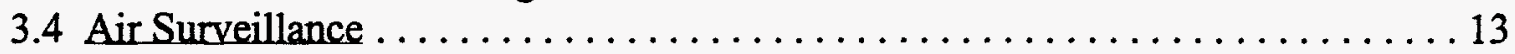

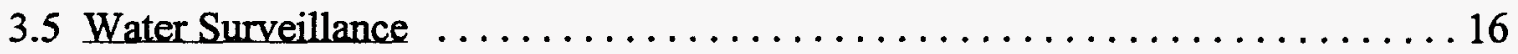

3.6 Soil and Sediment Surveillance . . . . . . . . . . . . . . . . . . . . 19

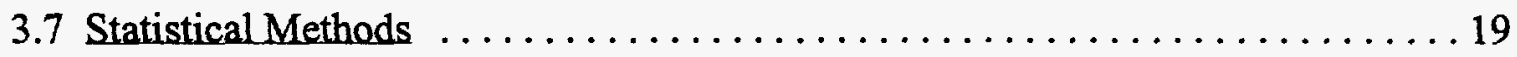

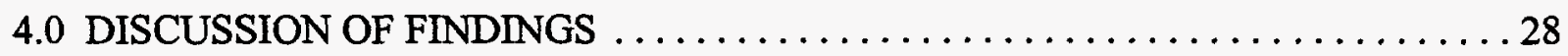

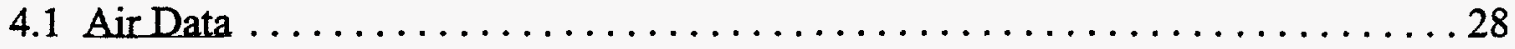

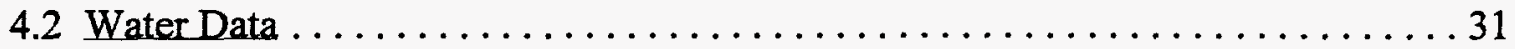

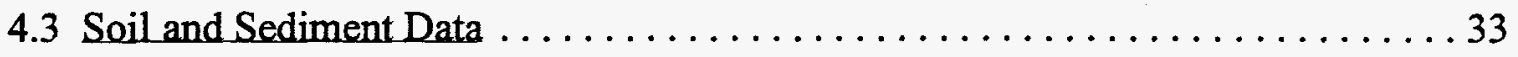




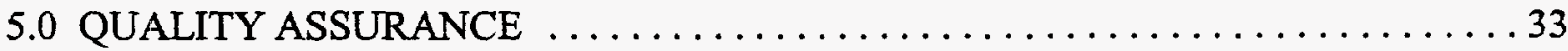

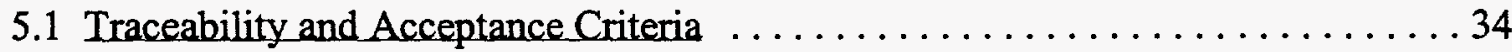

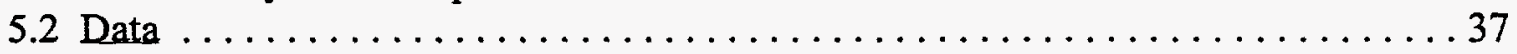

6.0 CONCLUSIONS $\ldots \ldots \ldots \ldots \ldots \ldots \ldots \ldots \ldots \ldots \ldots \ldots \ldots \ldots \ldots \ldots \ldots \ldots$

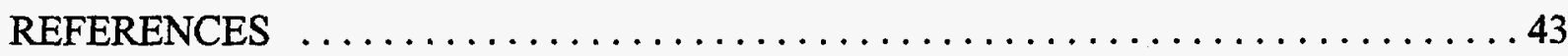

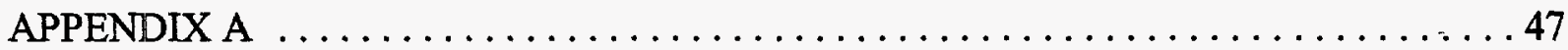

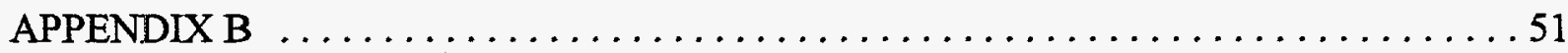

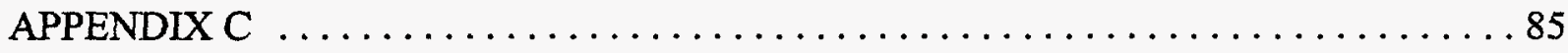

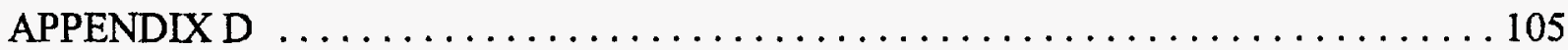

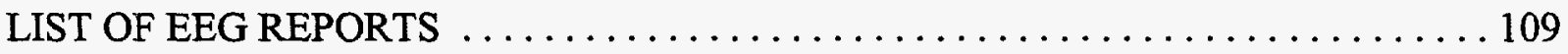




\section{LIST OF TABLES}

Page

Table 1. EEG Preoperational Radiological Sampling and Analysis Plan . . . . . . 10

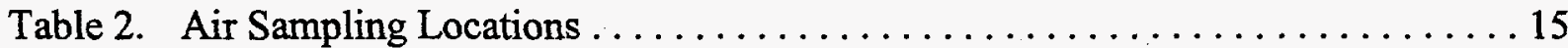

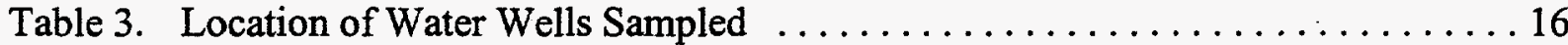

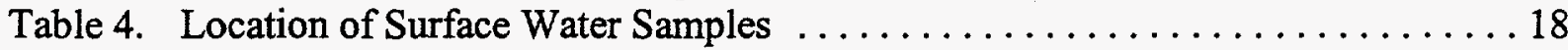

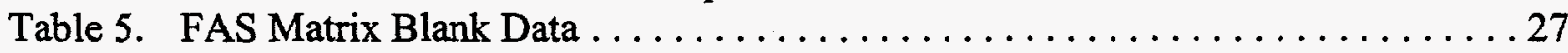

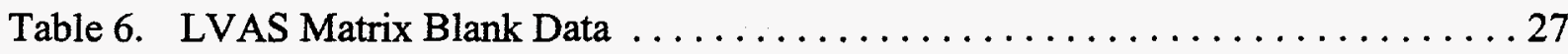

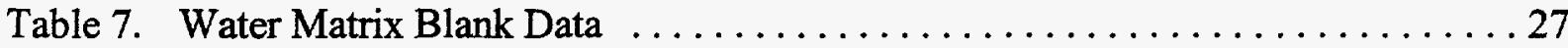

Table 8. Effluent Air Dose Estimates (NCRP \#123 Level I) . . . . . . . . . . . . . . 29

Table 9. Average Air Concentration of Actinides in New Mexico . . . . . . . . . 31

Table 10. Surface Water Dose Estimates (NCRP \#123 Level I) . . . . . . . . . . . 32

Table 11. Results of External QC Sample Analyses in Water . . . . . . . . . . . 38

Table 12. Results of External QC Sample Analyses in Air Filters . . . . . . . . . . . . 39

\section{LIST OF FIGURES}

Figure 1. Location of the WIPP Site $\ldots \ldots \ldots \ldots \ldots \ldots \ldots \ldots \ldots \ldots \ldots$

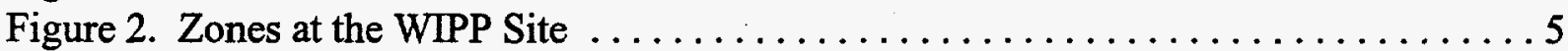

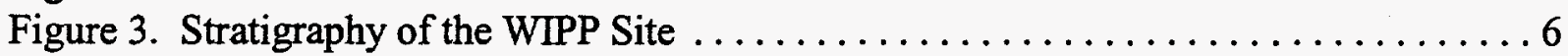

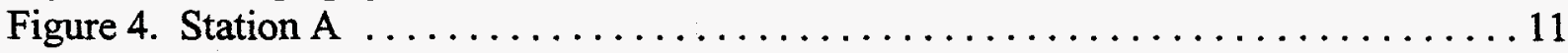

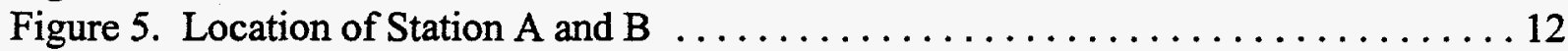

Figure 6. Typical WIPP Site Low Volume Air Sampling Station (S-3) . . . . . . . 13

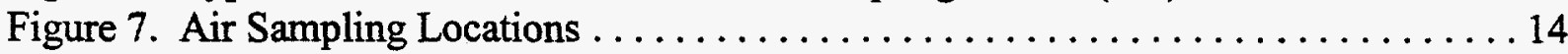

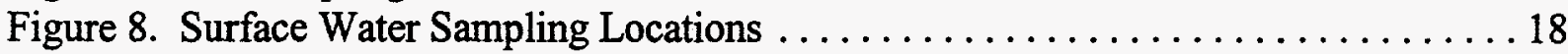

Figure 9. Comparison of EEG, LANL and EPA Average Actinide Concentration Data From Samples Collected in New Mexico from 1993-1995 . . . . . . . . . . . 30 


\section{LIST OF APPENDICES}

Appendix A: Excerpts from the Supplemental Stipulated Agreement $\ldots \ldots \ldots \ldots \ldots$

Appendix B:

Table B1. $\quad{ }^{241} \mathrm{Am}$ Concentrations in LVAS Samples During $1993 \ldots \ldots \ldots \ldots \ldots \ldots \ldots$

Table B2. $\quad{ }^{241}$ Am Concentrations in LVAS Samples During $1994 \ldots \ldots \ldots \ldots \ldots$

Table B3. $\quad{ }^{241}$ Am Concentrations in LVAS Samples During $1995 \ldots \ldots \ldots \ldots \ldots \ldots \ldots$

Table B4. $\quad{ }^{239+240} \mathrm{Pu}$ Concentrations in LVAS Samples During $1993 \ldots \ldots \ldots \ldots \ldots \ldots$

Table B5. $\quad{ }^{239+240} \mathrm{Pu}$ Concentrations in LVAS Samples During $1994 \ldots \ldots \ldots \ldots \ldots \ldots$

Table B6. $\quad{ }^{239+240} \mathrm{Pu}$ Concentrations in LVAS Samples During $1995 \ldots \ldots \ldots \ldots \ldots \ldots$

Table B7. $\quad{ }^{238} \mathrm{Pu}$ Concentrations in LVAS Samples During $1993 \ldots \ldots \ldots \ldots \ldots \ldots$

Table B8. $\quad{ }^{238} \mathrm{Pu}$ Concentrations in LVAS Samples During $1994 \ldots \ldots \ldots \ldots$

Table B9. $\quad{ }^{238} \mathrm{Pu}$ Concentrations in LVAS Samples During $1995 \ldots \ldots \ldots \ldots \ldots$

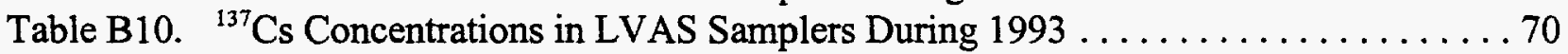

Table B11. ${ }^{137} \mathrm{Cs}$ Concentrations in LVAS Samples During $1994 \ldots \ldots \ldots \ldots \ldots \ldots . . \ldots \ldots 72$

Table B12. ${ }^{137} \mathrm{Cs}$ Concentrations in LVAS Samples During $1995 \ldots \ldots \ldots \ldots \ldots \ldots \ldots . \ldots 74$

Table B13. ${ }^{241}$ Am Concentrations in Station A Samples During 1993-1995 . . . . . . . . 76

Table B14. ${ }^{239+240} \mathrm{Pu}$ Concentrations in Station A Samples During 1993-1995 . . . . . . . 78

Table B15. ${ }^{238} \mathrm{Pu}$ Concentrations in Station A Samples During 1993-1995 . . . . . . . . . 80

Table B16. ${ }^{137} \mathrm{Cs}$ Concentrations in Station A Samples During 1993-1995 . . . . . . . . 82

Figure B1. ${ }^{241} \mathrm{Am}$ Concentrations in Air Particulates Collected in $1993 \ldots \ldots \ldots \ldots . \ldots 53$

Figure B2. ${ }^{241} \mathrm{Am}$ Concentrations in Air Particulates Collected in $1994 \ldots \ldots \ldots \ldots . \ldots . . .55$

Figure B3. ${ }^{241} \mathrm{Am}$ Concentrations in Air Particulates Collected in $1995 \ldots \ldots \ldots \ldots \ldots \ldots . . .57$

Figure B4. ${ }^{239+240} \mathrm{Pu}$ Concentrations in Air Particulates Collected in 1993 . . . . . . . . . . . 59

Figure B5. ${ }^{239+240} \mathrm{Pu}$ Concentrations in Air Particulates Collected in $1994 \ldots \ldots \ldots \ldots \ldots .61$

Figure B6. ${ }^{239+240} \mathrm{Pu}$ Concentrations in Air Particulates Collected in $1995 \ldots \ldots \ldots \ldots \ldots$

Figure B7. ${ }^{238} \mathrm{Pu}$ Concentrations in Air Particulates Collected in $1993 \ldots \ldots \ldots \ldots \ldots \ldots$

Figure B8. ${ }^{238} \mathrm{Pu}$ Concentrations in Air Particulates Collected in $1994 \ldots \ldots \ldots$. . . . . . . . 67

Figure B9. ${ }^{238} \mathrm{Pu}$ Concentrations in Air Particulates Collected in $1995 \ldots \ldots \ldots \ldots \ldots \ldots . .69$

Figure B10. ${ }^{137} \mathrm{Cs}$ Concentrations in Air Particulates Collected in $1993 \ldots \ldots \ldots \ldots \ldots \ldots . .71$

Figure B11. ${ }^{137} \mathrm{Cs}$ Concentrations in Air Particulates Collected in $1994 \ldots \ldots \ldots \ldots \ldots \ldots .73$

Figure B12. ${ }^{137} \mathrm{Cs}$ Concentrations in Air Particulates Collected in $1995 \ldots \ldots \ldots \ldots \ldots . \ldots 75$

Figure B13. ${ }^{241}$ Am Concentrations in Effluent Air Particulates 1993-1995 . . . . . . . . . 77

Figure B14. ${ }^{239+240} \mathrm{Pu}$ Concentrations in Effluent Air Particulates 1993-1995 . . . . . . . . . 79

Figure B15. ${ }^{238} \mathrm{Pu}$ Concentrations in Effluent Air Particulates 1993-1995 . . . . . . . . . . 81

Figure B16. ${ }^{137} \mathrm{Cs}$ Concentrations in Effluent Air Particulates 1993-1995 . . . . . . . . 83

Appendix C:

Table C1. $\quad{ }^{241}$ Am Concentrations in Public Water Systems During 1993-1995 . . . . . . . 86

Table C2. $\quad{ }^{239+240} \mathrm{Pu}$ Concentrations in Public Water Systems During 1993-1995 . . . . . . . 88

Table C3. $\quad{ }^{238} \mathrm{Pu}$ Concentrations in Public Water Systems During 1993-1995 . . . . . . . 90

Table C4. $\quad{ }^{241}$ Am Concentrations in Surface Water During 1993-1995 . . . . . . . . . . 92 
Table C5.

Table C6.

Table C7.

Table C8.

Table C9.

Figure $\mathrm{C}$.

Figure $\mathrm{C} 2$.

Figure $\mathrm{C} 3$.

Figure $\mathrm{C} 4$.

Figure $\mathrm{C} 5$.

Figure C6.

Figure $\mathrm{C} 7$.

Figure $\mathrm{C} 8$.

Figure $\mathrm{C}$.

${ }^{239+240} \mathrm{Pu}$ Concentrations in Surface Water During 1993-1995 ........... 94

${ }^{238} \mathrm{Pu}$ Concentrations in Surface Water During 1993-1995 ............. 96

${ }^{241} \mathrm{Am}$ Concentrations in Ground Water During 1993-1995 . . . . . . . . . . . . 98

${ }^{239+240} \mathrm{Pu}$ Concentrations in Ground Water During 1993-1995 . . . . . . . . . 100

${ }^{238} \mathrm{Pu}$ Concentrations in Ground Water During 1993-1995 ............ 102

${ }^{241}$ Am Concentrations in Public Water Systems 1993-1995 . . . . . . . . . . . 87

${ }^{239+240} \mathrm{Pu}$ Concentrations in Public Water Systems 1993-1995 . . . . . . . . . . 89

${ }^{238} \mathrm{Pu}$ Concentrations in Public Water Systems 1993-1995 . . . . . . . . . . . 91

${ }^{241} \mathrm{Am}$ Concentrations in Surface Water 1993-1995 . . . . . . . . . . . . . . . . 93

${ }^{239+240} \mathrm{Pu}$ Concentrations in Surface Water 1993-1995 ............... 95

${ }^{238} \mathrm{Pu}$ Concentrations in Surface Water 1993-1995 . . . . . . . . . . . . . . 97

${ }^{241} \mathrm{Am}$ Concentrations in Ground Water 1993-1995 . . . . . . . . . . . . . 99

${ }^{239+240} \mathrm{Pu}$ Concentrations in Ground Water 1993-1995 . . . . . . . . . . . . . 101

${ }^{238} \mathrm{Pu}$ Concentrations in Ground Water 1993-1995 . . . . . . . . . . . 103

Appendix D:

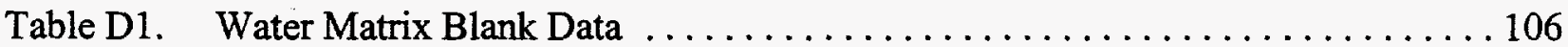

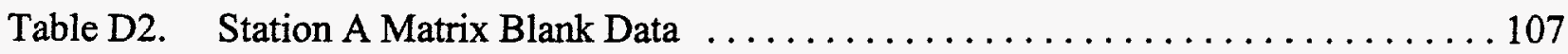

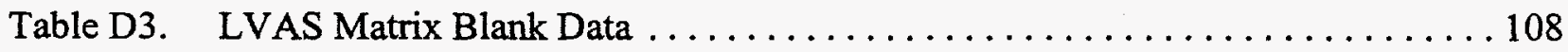




\section{ACRONYMS}

$\begin{array}{ll}\text { ACTL } & \text { Action Level } \\ \text { ANSI } & \text { American National Standards Institute } \\ \text { C \& C } & \text { Consultation and Cooperation } \\ \text { CAM } & \text { Continuous Air Monitor } \\ \text { CFR } & \text { Code of Federal Regulations } \\ \text { CH-TRU } & \text { Contact Handled Transuranic } \\ \text { Ci } & \text { Curies } \\ \text { DOE } & \text { U. S. Department of Energy } \\ \text { DQO } & \text { Data Quality Objectives } \\ \text { EEG } & \text { Environmental Evaluation Group } \\ \text { EML } & \text { Environmental Measurements Laboratory } \\ \text { EPA } & \text { U.S. Environmental Protection Agency } \\ \text { FAS } & \text { Fixed Air Sampler } \\ \text { FPM } & \text { Field Procedures Manual } \\ \text { GPS } & \text { Global Positioning System } \\ \text { HEPA } & \text { High Efficiency Particulate Air } \\ \text { ISO } & \text { International Standards Organization } \\ \text { LANL } & \text { Los Alamos National Laboratory } \\ \text { LPM } & \text { Laboratory Procedures Manual } \\ \text { LVAS } & \text { Low Volume Air Sampler } \\ \text { MDA } & \text { Minimum Detectable Activity } \\ \text { MDC } & \text { Minimum Detectable Concentration } \\ \text { NCRP } & \text { National Council on Radiation Protection and Measurements } \\ \text { NIST } & \text { National Institute of Standards and Technology } \\ \text { NRIP } & \text { NIST Radiochemistry Intercomparison Program } \\ \text { NRC } & \text { U. S. Nuclear Regulatory Commission } \\ \text { NTWMP } & \text { National Transuranic Waste Management Plan } \\ \text { QAP } & \text { Quality Assurance Program } \\ \text { QAPP } & \text { Quality Assurance Program Plan } \\ \text { QC } & \text { Quality Control } \\ \text { RH-TRU } & \text { Remote Handled Transuranic } \\ \text { ROI } & \text { Regions of Interest } \\ \text { TPU } & \text { Total Propagated Uncertainty } \\ \text { TRU } & \text { Transuranic } \\ \text { WHB } & \text { Waste Handing Building } \\ \text { WID } & \text { Waste Isolation Division } \\ \text { WIPP } & \text { Waste Isolation Pilot Plant } \\ & \end{array}$




\section{EXECUTIVE SUMMARY}

Average ${ }^{241} \mathrm{Am},{ }^{239+240} \mathrm{Pu}$ and ${ }^{238} \mathrm{Pu}$ concentrations measured in ambient air near the Waste Isolation Pilot Plant (WIPP) site during 1993, 1994 and 1995 are consistent with similar data reported by the U. S. Environmental Protection Agency (EPA) and Los Alamos National Laboratory (LANL) for Espanola, Pojoaque and Santa Fe, New Mexico.

Through the use of replicate analyses of matrix blanks minimum detectable activity (MDA), minimum detectable concentration (MDC) and action levels (ACTL) were established for the Environmental Evaluation Group (EEG) measurement system. Using MDA data from fixed air sampler (FAS) filters and conservative assumptions applied in the National Council on Radiation Protection and Measurements (NCRP) Report 123 (NCRP 1996), it is shown that the EEG sampling and measurement methodology is capable of detecting effluent air emissions which would produce a dose that is approximately 1000 times below the 40 CFR 191 Subpart A limit of $2.5 \mathrm{E}^{-4} \mathrm{~Sv} / \mathrm{y}(25 \mathrm{mrem} / \mathrm{y})$. A similar calculation using the NCRP worksheet with storm water effluent MDCs found the EEG measurement program capable of detecting actinide emissions which would result in a dose that is approximately 10 times below the dose limits in 40 CFR 191 Subpart A and 40 CFR 61 Subpart H.

The EPA guidance for implementation of 40 CFR 191 subpart A states that the EPA expectation is that monitoring of radionuclide emissions should be capable of detecting one tenth of the 25 $\mathrm{mrem} / \mathrm{y}$ public dose limit. Data in this report indicate that the EEG monitoring program is capable of measuring such levels.

The EEG internal and external quality control (QC) programs reflect the quality of environmental measurements contained in this report. Through the analysis of external National Institute of Standards and Technology (NIST) and Environmental Measurements Laboratory (EML) samples the required precision and accuracy is demonstrated. 


\subsection{INTRODUCTION}

The Environmental Evaluation Group's (EEG) radiological surveillance program's purpose is to independently measure background radioactivity in air, water and soil at the Waste Isolation Pilot Plant (WIPP) and in surrounding communities. The WIPP is intended to be a repository for the disposal of transuranic (TRU) radioactive waste resulting from defense activities of the United States.

Environmental monitoring began in 1984 under the terms of the July 1981 Consultation and Cooperation (C \& C) Agreement and the December 1982 Supplemental Stipulated Agreement (NM v. US DOE 1982) which is summarized in Appendix A. The National Defense Authorization Act for Fiscal Year 1997, Public Law 103-160 (US Congress 1993) authorized continued funding.

The EEG's initial objective was to verify the accuracy and precision of the Department of Energy's (DOE) environmental program (Spiegler 1984). Data collected during the program is contained in Kenney et al. (1990), Kenney and Ballard (1990), Kenney (1991), Kenney (1992) and Kenney (1994). The WIPP was and remains exempt from Nuclear Regulatory Commission (NRC) licensing and inspection. The EEG's role insures public confidence and acceptance of monitoring results. Environmental samples are independently collected by EEG, although some water samples and effluent air samples are collected with the assistance of the Waste Isolation Division (WID) of Westinghouse Electric Corporation, the DOE's management and operating contractor for WIPP site activities.

Environmental samples were originally analyzed by independent laboratories not affiliated with the DOE. In 1993, the EEG established a radiochemical laboratory because of inconsistencies noted with commercial laboratory analyses (Rodgers and Kenney 1997). Subsequently, the EEG helped establish a laboratory intercomparison program with the National Institute of Standards and Technology (NIST). The intercomparison program helps participating laboratories to maintain a high level of accuracy and precision in radiochemical analyses. 
Although the present program is based on the 1982 Supplemental Stipulated Agreement, monitoring capabilities have been greatly enhanced by the addition of on-site air sampling, including daily samples from the underground effluent exhaust system.

The EEG screens the daily air samples for radioactivity, and if necessary, will collect special samples if a radiological release is suspected. Daily sampling filters are also composited for more sensitive radiochemical analysis.

The on-site sampling provides the greatest assurance that no radioactivity releases have occurred. Air, water and soil samples were obtained from nearby communities and the Gnome site. Gnome was the site of a 1961 underground nuclear detonation about $8.8 \mathrm{~km}(5.5 \mathrm{mi})$ southwest of the WIPP site boundary. The more distant sampling provides an indiction of environmental radioactivity variations in southeast New Mexico. Community sampling is also useful in discriminating non-WIPP radioactivity, such as occurred from Chernobyl nuclear fallout in 1986.

\subsection{WIPP SITE INFORMATION}

\subsection{Radioactive Waste Inventory}

Under terms of the Waste Isolation Pilot Plant Land Withdrawal Act, Public Law 102-579 (US Congress 1992) the facility is limited to a maximum waste volume capacity of $176,000 \mathrm{~m}^{3}(6.2$ million cubic feet) and a maximum remote handled transuranic (RH-TRU) activity of 5,100,000 Ci. Current estimates of waste volume designated for disposal at WIPP are contained in the National TRU Waste Management Plan (NTWMP) (US DOE, CAO 1997). Waste volume estimates in the NTWMP are $161,372 \mathrm{~m}^{3}\left(5.69 \times 10^{6} \mathrm{ft}^{3}\right)$ of contact handled transuranic $(\mathrm{CH}-$ TRU) and 3,934 $\mathrm{m}^{3}\left(1.39 \times 10^{5} \mathrm{ft}^{3}\right)$ of RH-TRU ultimately available for disposal at WIPP. 


\subsection{Regulatory Requirements}

Although the WIPP facility is exempt from the U.S. Nuclear Regulatory Commission regulations (US Congress 1992), the U.S. Environmental Protection Agency (EPA) was given regulatory authority in 40 CFR 191 and 40 CFR 61 (US EPA 1990a, b). Subpart A of 40 CFR 191 established a regulatory limit for the combined annual radiation does to the public of 25 mrem to the whole body and 75 mrem to any critical organ. 40 CFR 61 (US EPA 1990b) limits public doses from normal WIPP operations to 10 mrem per year. When WIPP begins the disposal phase, the effective dose from WIPP emissions will be limited by the requirements of 40 CFR 191 Subpart A and 40 CFR 61 Subpart H (US DOE, WIPP 1997b). The EPA regulations generally apply to routine emissions from the WIPP operation, and normal radioactivity releases are not expected to approach any of the regulatory limits.

\subsection{General Area}

The WIPP facility is located in Eddy County in southeastern New Mexico, approximately $42 \mathrm{~km}$ (26 mi) east of Carlsbad (Figure 1). The facility is located on a sandy plain at an elevation of $1,040 \mathrm{~m}(3,410 \mathrm{ft})$ above sea level. Prominent natural features near the facility include the Livingston Ridge and Nash Draw, about $8 \mathrm{~km}(5 \mathrm{mi})$ west of the facility. Nash Draw is a shallow drainage course between $8 \mathrm{~km}(5 \mathrm{mi})$ and $18 \mathrm{~km}(11 \mathrm{mi})$ in width, characterized by surface impoundments of brine water. Livingston Ridge is a bluff that marks the eastern edges of Nash Draw. Other prominent features of the region include the Pecos River, located about 22 $\mathrm{km}$ (14 mi) west of the facility, and the Carlsbad Caverns National Park about $68 \mathrm{~km}$ (42 mi) west-southwest of the WIPP facility. 


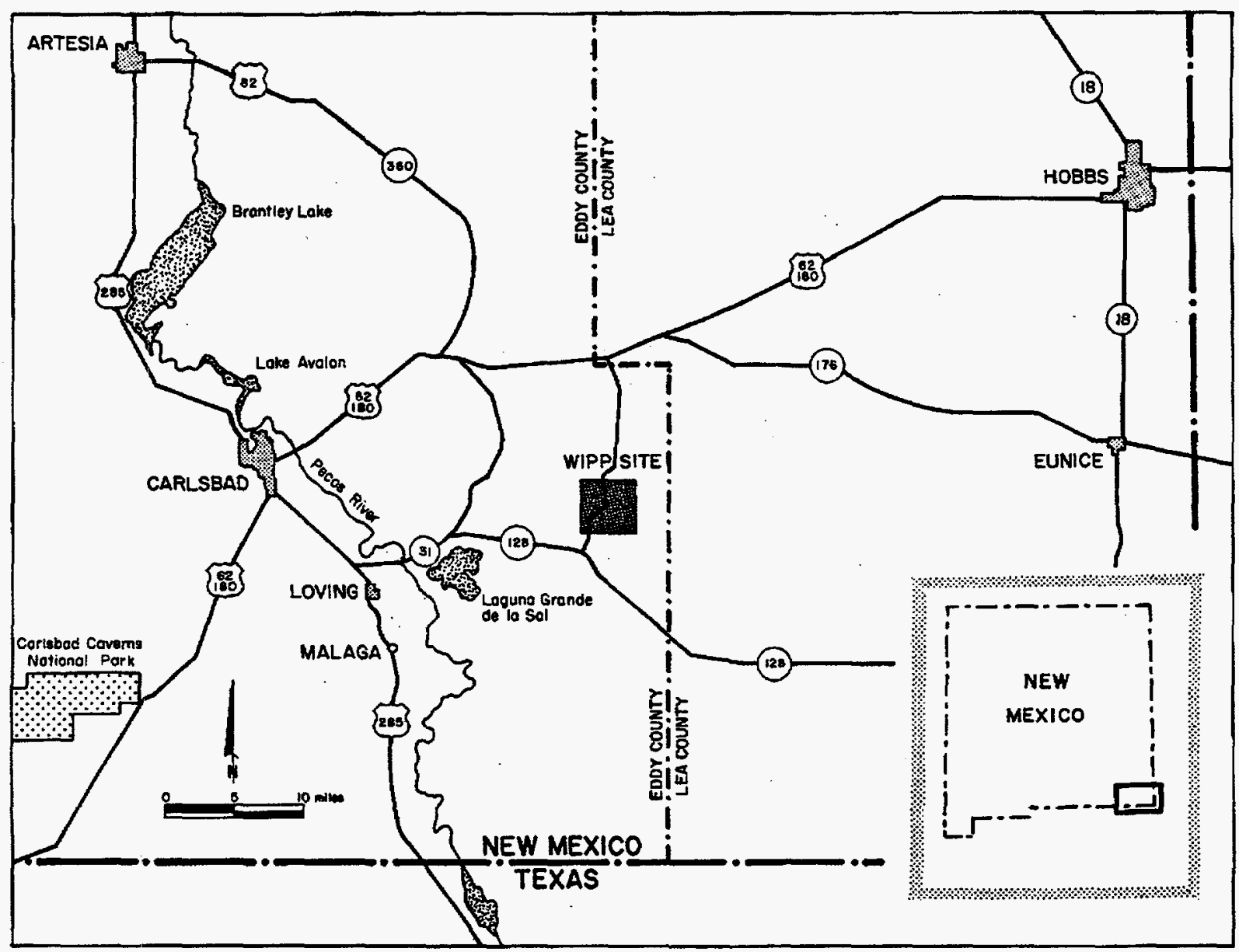

Figure 1. Location of the WIPP Site

The nearest population centers are the village of Loving (population 1,500) located $29 \mathrm{~km}(18$ mi) southwest of the facility, and the city of Carlsbad (population 28,400) located $42 \mathrm{~km}$ (26 mi) west of the facility. Other New Mexico towns within an $80 \mathrm{~km}$ (50 mi) radius include Artesia, Eunice, Hobbs, Jal, and Lovington.

The climate in the region of the facility is semi-arid with an average annual precipitation in Carlsbad of $325 \mathrm{~mm}$ (12.79 in) between 1961 and 1990. During 1993, 1994 and 1995 Carlsbad reported an annual precipitation total of $284 \mathrm{~mm}$ (11.17 in), $262 \mathrm{~mm}$ (10.33 in) and $189 \mathrm{~mm}$ ( 7.45 in) respectively (US DOC 1993, 1994, 1995). The average rainfall during this report period was $245 \mathrm{~mm}$ (9.6 in). Much of the precipitation falls during intense thunderstorms in the 
spring and summer. Winds are predominantly from the southeast toward the northwest (US DOE, WIPP 1991).

\subsection{WIPP Site}

Surface structures of the facility are located in sections 20 and 21 of township 22 south, range 21 east, in Eddy County, New Mexico. The surface areas around WIPP are divided into several areas (US DOE, WIPP 1997a) as indicated in Figure 2. The "property protection area" is 14 ha (35 acres) and contains most of the surface structures associated with WIPP. This area is enclosed by chain link fence and patrolled by

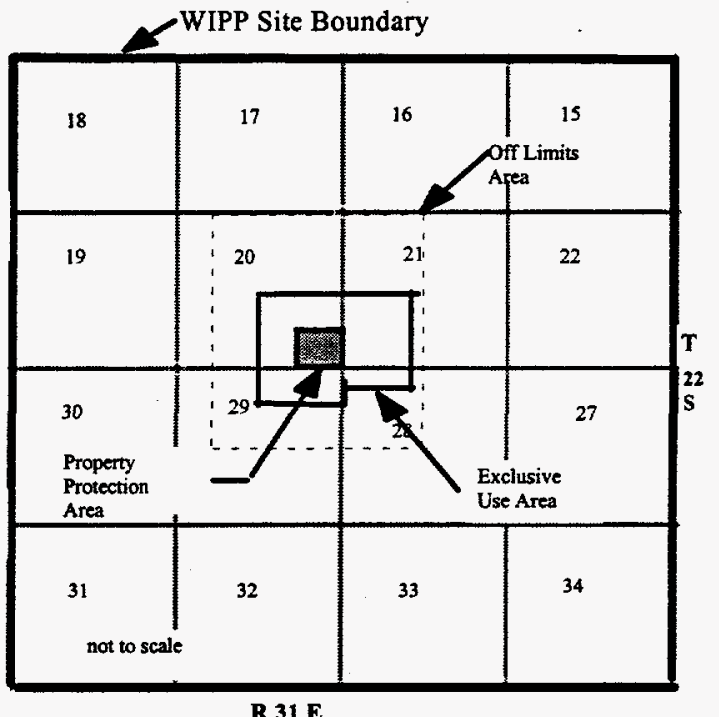

Figure 2. Zones at the WIPP Site security guards to maintain restricted access. The "exclusive use area" encompasses 171 ha (424 acres), surrounds the property protection area and is marked with a barbed wire fence. The "off-limits area" is the next larger subdivision encompassing 587 ha (1,450 acres) and is posted as a no trespassing area. The 4,144 ha (16 square mile) outermost facility boundary surrounding the exclusive use area is the "WIPP site boundary".

\subsection{Geology}

Geologically, the WIPP repository horizon is situated at a depth of $655 \mathrm{~m}(2,150 \mathrm{ft})$ below land surface in the Permian Age Salado Formation (Figure 3). The Salado is a $610 \mathrm{~m}(2,000 \mathrm{ft})$ thick bedded-salt formation overlain by the Rustler Formation. The Rustler Formation consists of anhydrite and siltstone beds and contains two water-bearing zones, the magenta and culebra dolomites, at $170 \mathrm{~m}(568 \mathrm{ft})$ and $205 \mathrm{~m}(672 \mathrm{ft})$ below land surface, respectively. Each of these 
is approximately $7.5 \mathrm{~m}(25 \mathrm{ft})$ thick. Transport in the water-bearing units of the Rustler Formation represents the main potential hydrologic pathway to the biosphere from the repository. The culebra dolomite is considered to be the most important hydrologic pathway for release calculations because it is the most transmissive unit in the area. An interpretation (Sandia 1989) of the Culebra freshwater-head data indicates a southerly flow across the WIPP site. The flow turns to the southwest south of the site. Radiological baseline data for the culebra are being collected because of their importance to long-term release scenarios.

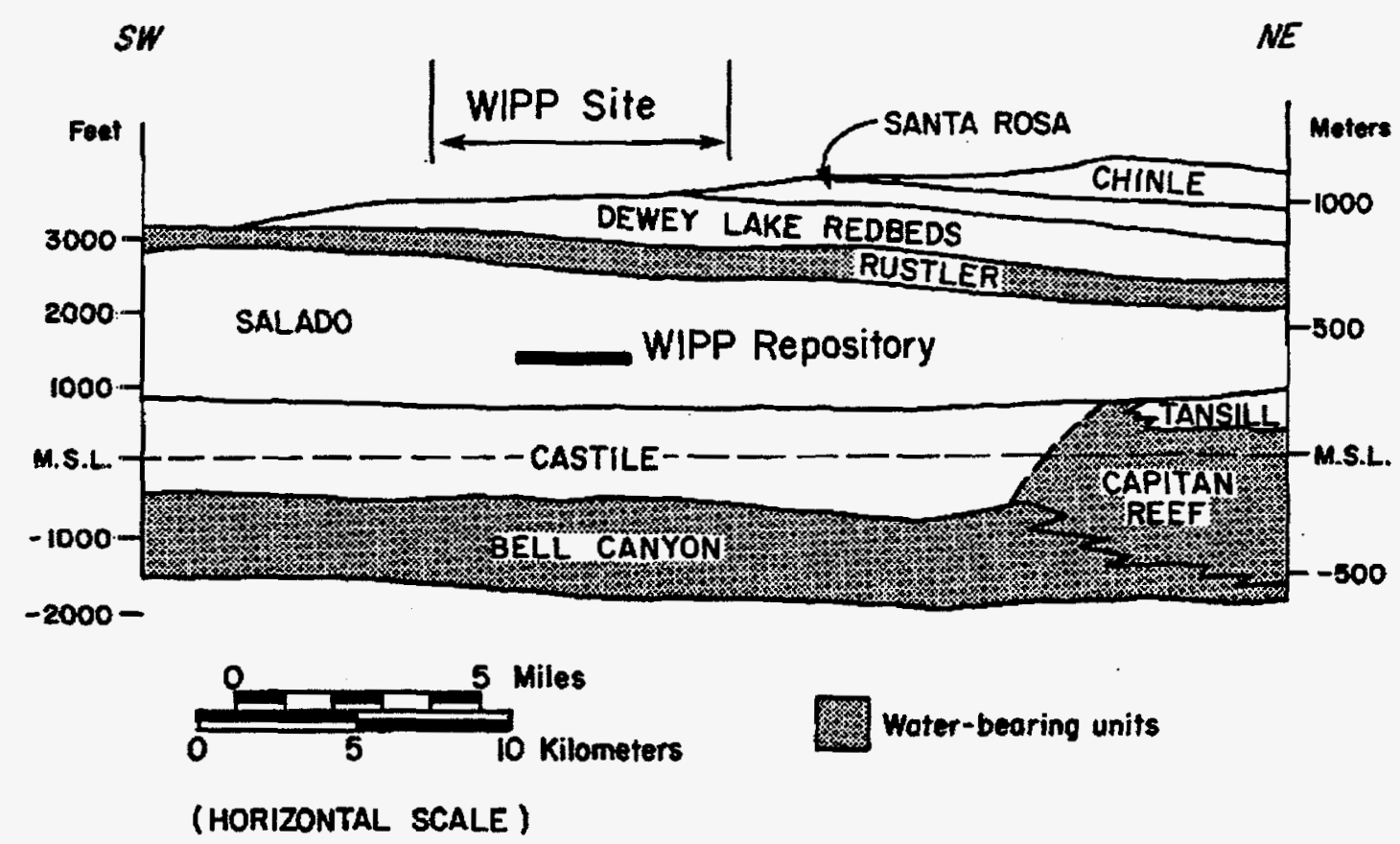

Figure 3. Stratigraphy of the WIPP Site

Chaturvedi and Channell (1985) suggested that the two major discharge points for waters from the Rustler Formation, which overlies the WIPP repository are the Pecos River in an area known as Malaga Bend and Laguna Grande de la Sal. The Laguna Grande de la Sal receives flow from several springs along the margin of the lake. Potentiometric contours for various zones within the Rustler point to the Laguna Grande de la Sal as a secondary discharge point for the Rustler water. Because the Rustler Formation lies directly above the Salado Formation which contains 
the WIPP repository, EEG includes water samples from the discharge areas of the Rustler Formation in the radionuclide baseline program.

\subsection{Occupational Industries}

Three ranches (Mills, Smith, and Mobley) have property in the vicinity of the WIPP facility. The Mills ranch headquarters is located $5.6 \mathrm{~km}(3.5 \mathrm{mi})$ south-southwest of the facility center, the Smith headquarters is $8.8 \mathrm{~km}$ (5.5 mi) west-northwest of the facility, and the Mobley ranch is $9.6 \mathrm{~km}(6 \mathrm{mi})$ southwest of the facility. Several earthen rain water catchment tanks used for cattle watering are located near the WIPP site. Noya, Hill, Indian and Red tanks collect water over a large area that is subject to atmospheric fallout and are ideal environmental sampling points.

Although there are no dairies within 40 kilometers (25 miles) of the WIPP facility, a large amount of alfalfa is grown in the Pecos Valley between Roswell and Malaga, New Mexico. The alfalfa crop is used in cattle feeding operations mainly in New Mexico and Texas. Cotton and pecans are the other major crops grown in the Pecos Valley.

DOE has purchased all potash leases within the 16 sections comprising the WIPP facility. However, there are two active oil and gas leases in the southwest corner of the WIPP site. The first well is in the north-half of section 31 and the second in the south-half of section 31, T-22-S, R-31-E (Silva and Channell 1992). These two oil and gas leases are at depths greater than 6,000 feet and are part of the James Ranch Unit.

\subsection{Gnome Site}

In 1961 the Atomic Energy Commission detonated a nuclear device $370 \mathrm{~m}$ (1216 ft) below land surface at the Gnome Site which is located approximately $8.8 \mathrm{~km}(5.5 \mathrm{mi})$ southwest of the WIPP Site boundary. The Gnome Project was part of the Plowshare Program to demonstrate the peaceful use of atomic energy. Following detonation fission products vented from the underground for more than 24 hours. In 1994, an EEG environmental survey of the plume 
fallout area indicated measurable concentrations of ${ }^{241} \mathrm{Am},{ }^{238} \mathrm{Pu}$, and ${ }^{239+240} \mathrm{Pu}$ on the ground surface (Kenney et al. 1995). However, the radionuclide concentrations measured at Gnome were well below typical clean-up levels.

\subsection{ENVIRONMENTAL PROGRAM DESCRIPTION}

The EEG radiation surveillance program is limited in scope compared to the WIPP's. The primary program elements are designed to maintain public confidence that there are no significant radioactive releases from the WIPP, and that WIPP radionuclides are not present in key air and food chain pathways.

\subsection{Program Overview}

The current EEG preoperational environmental sampling and analytical plan is shown in Table 1. The four major elements of the program are air, surface water, groundwater and facility effluent sampling. At present, soil and vegetation samples are not routinely acquired and analyzed.

The three air samplers on the WIPP site are located in the most prevalent downwind directions from the facility, and although they might be useful in confirming accidental releases, the primary purpose is to obtain baseline data. One sampler is located within the property protection area (Figure 2). Air samplers near population centers are also important in documenting the variability of the radioactivity background, and serve as assurance to the public that WIPP radionuclides are not present in the area.

Surface water samples are taken from stock tanks, the Pecos River and Laguna Grande de la Sal. The tank sample data are important for baseline radioactivity and animal-to-man food chain analyses. If a radioactive air plume were released at the WIPP, the tanks would be important sampling points. It is unlikely that radioactivity from WIPP sould enter the Pecos River or Laguna Grande de la Sal, but these sampling site data are useful for long-term monitoring and public assurance and verification that there are no WIPP radionuclides at these locations. 
Groundwater and municipal drinking water samples are also routinely acquired. These sampling locations are not likely to be affected by any WIPP radioactivity releases, but because water is a primary vector in the food chain, the samples are collected and analyzed. As with community air sampling, the verification of no WIPP radionuclides provides public assurance.

Facility effluents are the most likely pathway for accidental radioactivity releases from the WIPP. Accident release scenarios are postulated in the WIPP Safety Analysis Report (US DOE, WIPP 1997a). If an underground operations accident were to occur, air samples would be collected from Stations A and B, the final release points of the underground repository exhaust ventilation. Consequently, the EEG collects sampling filters from Station A each day, screens the filters for radioactivity, and performs the more sensitive radiochemical analyses on the composited quarterly samples. The daily sampling program allows a careful study of the variability of radioactivity background and trends.

Storm water runoff is collected from areas that could potentially become contaminated from residues on transport vehicles or TRUPACT-II containers or atmospheric fallout. These samples establish a background needed to provide operational assurance that contamination has not been carried outside of the controlled areas by storm water runoff.

From time to time, soil and vegetation samples will be taken to verify WIPP measurements and to establish the variability of background radioactivity. The EEG tested techniques and methods in a limited study at the Gnome site. The results of this study were reported in EEG-58 (Kenney et al. 1995). 
Table 1. EEG Preoperational Radiological Sampling and Analysis Plan

\begin{tabular}{|c|c|c|c|}
\hline $\begin{array}{c}\text { Environmental } \\
\text { Medium }\end{array}$ & Location & $\begin{array}{l}\text { Sample/Analysis } \\
\text { Frequency }\end{array}$ & Parameter \\
\hline Air & $\begin{array}{l}4 \text { Off-site and } 3 \text { on-site Low } \\
\text { Volume Air Sampler } \\
\text { Locations }\end{array}$ & $\begin{array}{l}\text { Continuously/ } \\
\text { Quarterly Composite }\end{array}$ & $\begin{array}{l}\mathrm{Pu}-238, \mathrm{Pu}-239+240, \mathrm{Am}- \\
241, \mathrm{Cs}-137\end{array}$ \\
\hline Surface Water & $\begin{array}{l}\text { Pecos River } 2 \text { locations } \\
\text { Laguna Grande de La Sal } \\
\text { Surface Stock Tanks } \\
5 \text { Locations }\end{array}$ & Annually/Annually & $\begin{array}{l}\mathrm{Pu}-238, \mathrm{Pu}-239+240, \mathrm{Am}- \\
241\end{array}$ \\
\hline Groundwater & 15 Wells & $\begin{array}{l}\text { As Available/ } \\
\text { Annually }\end{array}$ & $\begin{array}{l}\mathrm{Pu}-238, \mathrm{Pu}-239+240, \mathrm{Am}- \\
241\end{array}$ \\
\hline $\begin{array}{l}\text { Municipal } \\
\text { Drinking Water }\end{array}$ & 4 Systems & Annually/Annually & $\begin{array}{l}\mathrm{Pu}-238, \mathrm{Pu}-239+240, \mathrm{Am}- \\
241\end{array}$ \\
\hline \multicolumn{4}{|l|}{ Facility Effluents } \\
\hline Air & $\begin{array}{l}2 \text { Underground Ventilation } \\
\text { Exhaust (Stations A \& B) }\end{array}$ & $\begin{array}{l}\text { Continuously/ } \\
\text { Quarterly Composite }\end{array}$ & $\begin{array}{l}\text { Pu-238, Pu-239+240, Am- } \\
241, \text { Cs- } 137\end{array}$ \\
\hline $\begin{array}{l}\text { Storm Water } \\
\text { Runoff }\end{array}$ & WIPP Zone I Effluent & Annually/Annually & $\begin{array}{l}\text { Pu-238, Pu-239+240, Am- } \\
241\end{array}$ \\
\hline
\end{tabular}

Note: The results of soil samples collected and analyzed during 1994 \& 1995 can be found in EEG Report \#58 (Kenney et al. 1995).

\subsection{Radionuclides of Interest}

Prior to 1993 samples were sent to a contract laboratory and analyzed for ${ }^{238} \mathrm{Pu},{ }^{239+240} \mathrm{Pu},{ }^{241} \mathrm{Am}$ ${ }^{137} \mathrm{Cs},{ }^{233+234} \mathrm{U},{ }^{235} \mathrm{U},{ }^{228} \mathrm{Th},{ }^{230} \mathrm{Th},{ }^{232} \mathrm{Th}$ and ${ }^{90} \mathrm{Sr}$. In 1993 EEG developed its own radiochemical laboratory. For samples collected after 1992 this list was reduced to ${ }^{238} \mathrm{Pu},{ }^{239+240} \mathrm{Pu},{ }^{241} \mathrm{Am}{ }^{137} \mathrm{Cs}$, ${ }^{233+234} \mathrm{U},{ }^{235} \mathrm{U},{ }^{228} \mathrm{Th},{ }^{230 \mathrm{Th}}$ and ${ }^{232} \mathrm{Th}$. This suite was further reduced to ${ }^{238} \mathrm{Pu},{ }^{239+240} \mathrm{Pu},{ }^{241} \mathrm{Am}$ and ${ }^{137} \mathrm{Cs}$ measurements. The radionuclides in the new reduced analytical suite, with the addition of ${ }^{90} \mathrm{Sr}$, account for $99 \%$ of the potential public radiation dose from WIPP operations. 
Other radionuclides may be added to the laboratory analysis, depending on the WIPP inventory content and their potential value as environmental indicators. The EEG plans to develop methods for analytical measurement of ${ }^{90} \mathrm{Sr}$ in the near future.

All sample analyses for this report were performed by EEG's radiochemistry laboratory.

\subsection{WIPP Effluent Monitoring}

Unfiltered exhaust air from the underground repository is the most important WIPP effluent.

The exhaust air is normally unfiltered because of the mine safety requirement for high underground air ventilation. The nominal underground exhaust air flow is $200 \mathrm{~m}^{3} / \mathrm{s}(425,000$ $\mathrm{scfm}$ ) and is reduced to $28.3 \mathrm{~m}^{3} / \mathrm{s}$ $(60,000 \mathrm{scfm})$ when two banks of high efficiency particulate air (HEPA) filters are employed (US DOE, WIPP 1997a).

EEG collects sampling filters each day from a FAS located in Station A. Sample lines with specially designed shrouded probes extend into the exhaust shaft as shown in Figure 4. Sampling line and shrouded probe testing confirmed that this configuration allows collection of representative air samples (Chandra et al. 1993). The recently activated Station B was not operational during the time of this study. Station B also contains

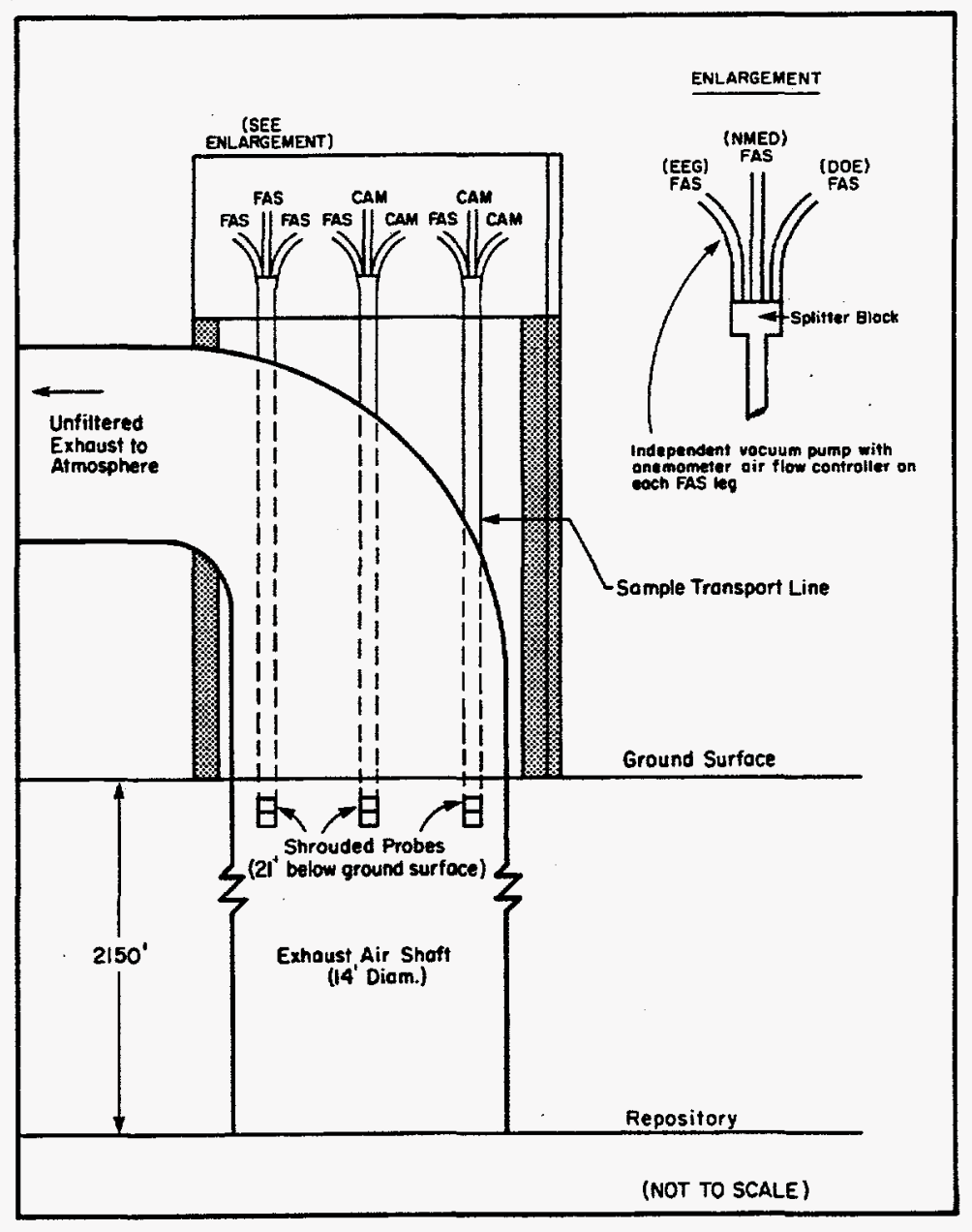

Figure 4. Station A 


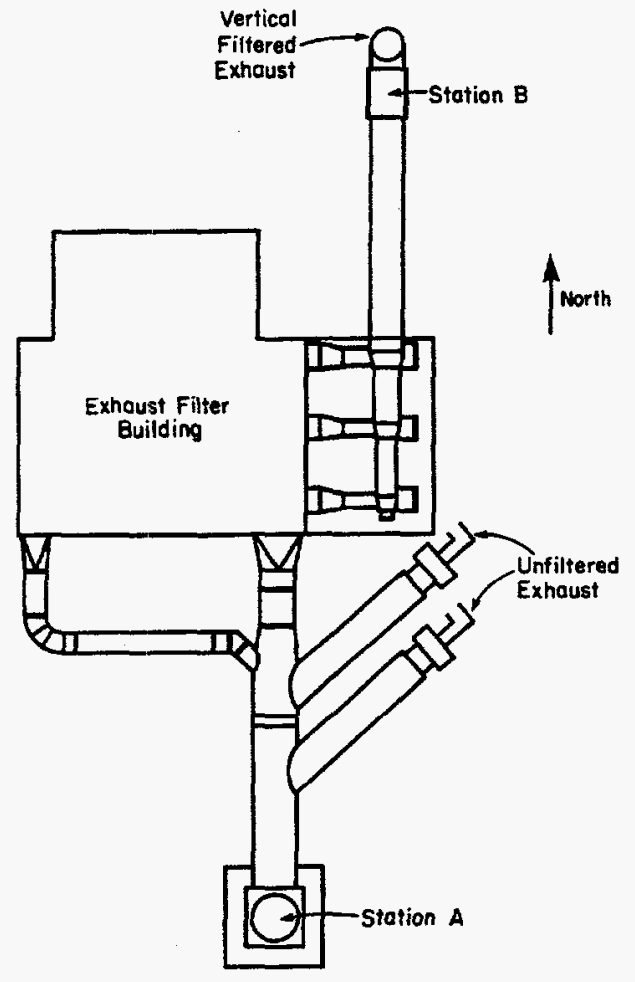

Figure 5. Location of Station $A$ and $B$ sampling lines with shrouded probes, and this configuration was tested to confirm that representative samples will be collected from the post-filter air exhaust stream. The EEG will routinely collect samples at Stations A \& B during operations (Figure 5).

The FAS flow rate at Stations A and B is 0.057 $\mathrm{m}^{3} / \mathrm{min}(2 \mathrm{scfm})$. Station A sampling filters are changed following approximately 24 hours of sampling, resulting in a nominal sample volume of $82 \mathrm{~m}^{3}\left(2,880 \mathrm{ft}^{3}\right)$. During the preoperational period, filters have not been changed on weekends and holidays due to the low accumulation of mining dust on the filters. Quarterly composites of FAS filters contain an air sample volume of approximately $7,344 \mathrm{~m}^{3}\left(259,200 \mathrm{ft}^{3}\right)$.

A tamper evident seal is installed on the FAS with each new filter. FAS air flow is regulated by an anemometer and flow controller, and electronically recorded each minute. EEG staff are present for each filter exchange and collect electronic data from a recorder at Station $A$ at the time of filter exchange.

Waste Handling Building (WHB) air effluent passes through two banks of HEPA tilers prior to discharge. DOE maintains continuous air monitors (CAMs) and FASs at Station $\mathrm{C}$ that records post-filter radioactivity background in the WHB exhaust duct. Due to the low probability of a release through this redundant HEPA filtered discharge, EEG does not collect air samples from Station C.

The second effluent stream from the WIPP facility is storm water discharged from the property protection area. Rainfall on the paved areas around the facility collects in drainage-ways before 
discharge into evaporation/seepage areas outside of the property protection area. Should radionuclides be present on the buildings, equipment or paved areas they could be present in the storm water effluent. EEG collects this storm water effluent when available and will collect soil/sediment samples from areas which receive this effluent during the preoperational and operational phases.

\subsection{Air Surveillance}

Ambient air sampling (as opposed to the effluent air sampling from Stations A and B) is conducted by the strategic placement of low volume air samplers at the WIPP facility (Figure 6). The Site-1 (S-1) sampler is located approximately 225 meters $(738 \mathrm{ft})$ north northwest of the WIPP exhaust shaft inside the property protection area. The low volume air sampler (LVAS) designated as Site-2 (S-2) is located approximately $500 \mathrm{~m}$ $(1,600 \mathrm{ft})$ northeast of the WIPP exhaust

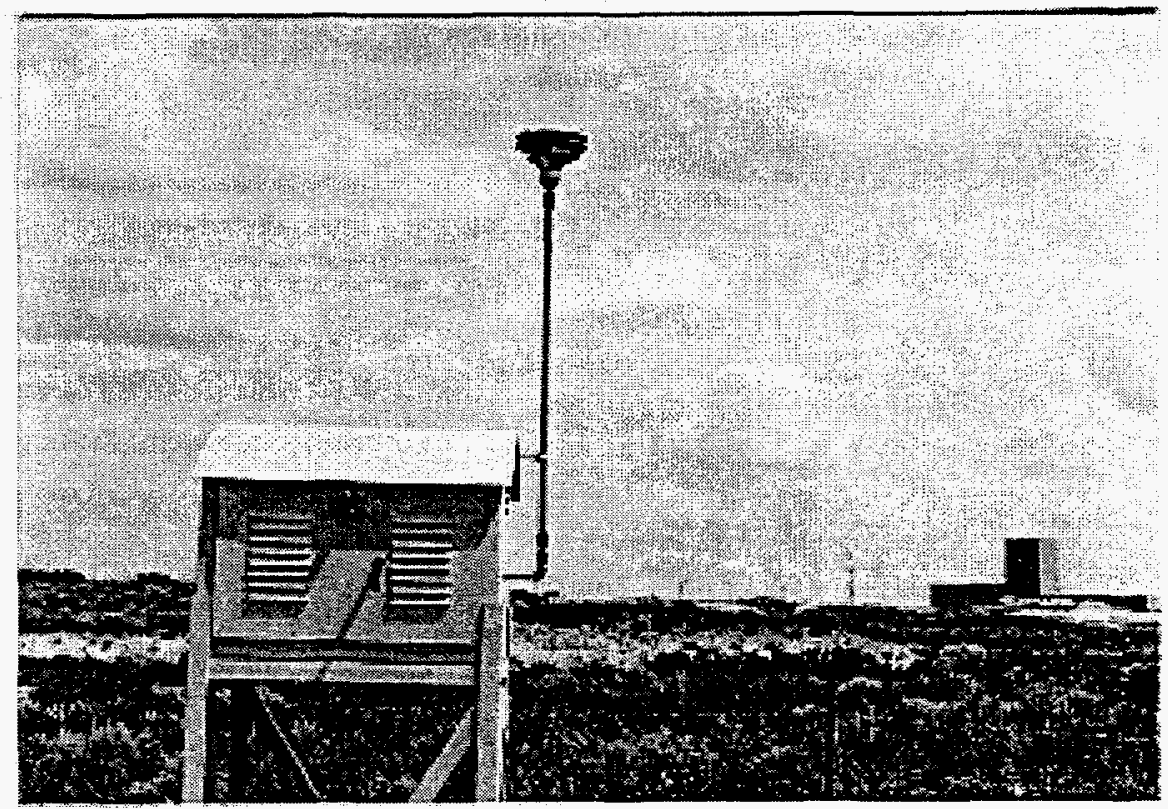

Figure 6. Typical WIPP Site Low Volume Air Sampling Station (S-3) shaft and the Site-3 LVAS (S-3) is located approximately $1,000 \mathrm{~m}(3,300 \mathrm{ft})$ northwest of the WIPP exhaust shaft in the predominate downwind direction from the exhaust stacks (Figure 7). 


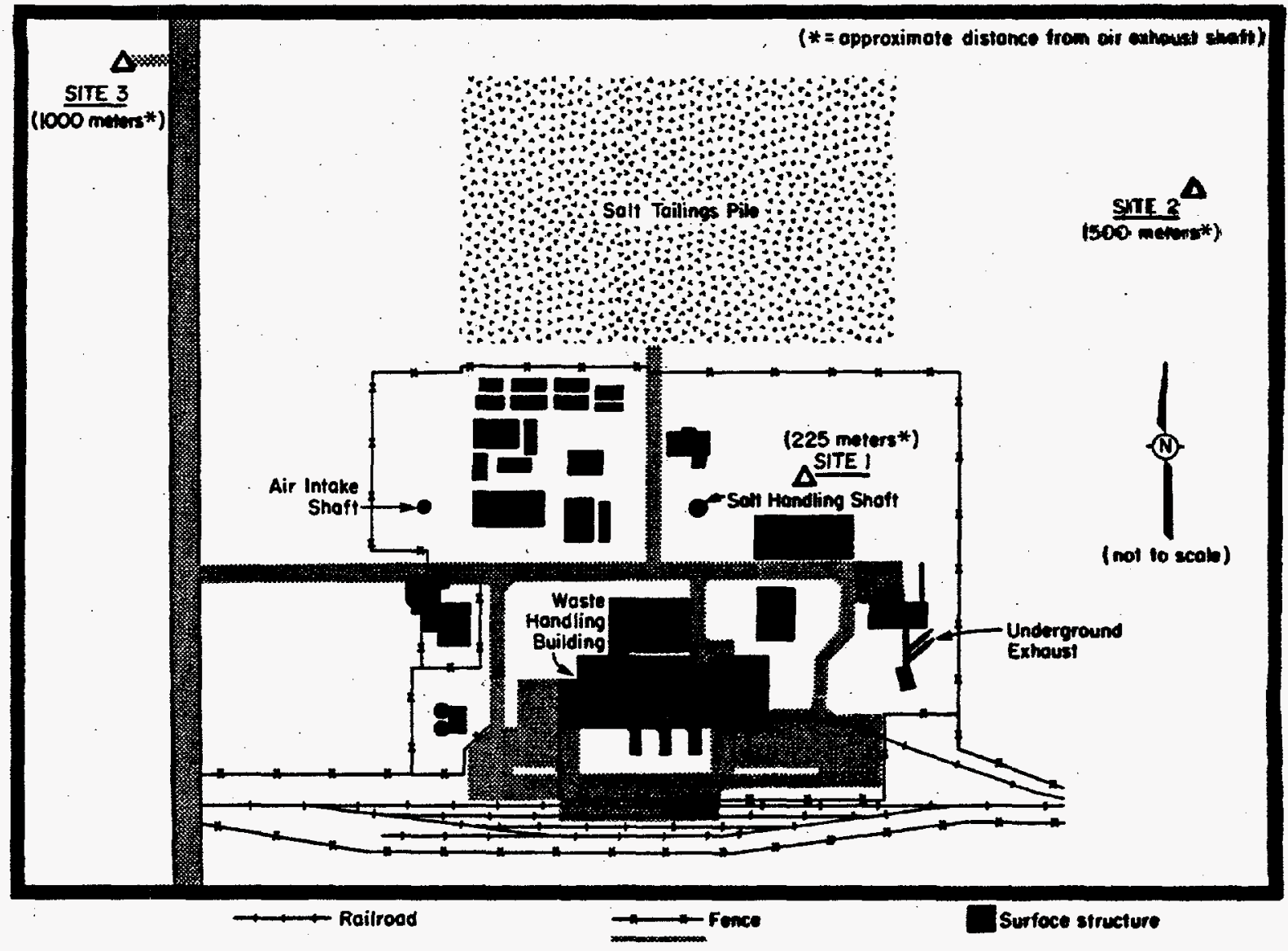

Figure 7. Air Sampling Locations

In addition low volume air samplers are also continuously operated in Artesia, Carlsbad, Hobbs, and Loving, New Mexico. The LVAS in Artesia is located near the west end of Jaycee Park near the intersection of 26th and Dr. R. W. Harper Drive (township 22S, range 25E, section 24). The Carlsbad LVAS is located at 505 N. Main Street (township 22S, range 27E, section 6). The Loving LVAS is located near the intersection of 5th Street and Elm Street at the Loving Fire Station (township 23S, range 28E, section 21). The LVAS in Hobbs is located near the intersection of Dalmont Street and Snyder Street (township 18S, range 38E, section 34).

The latitude and longitude of each air sampling location is shown in Table 2. The coordinates were obtained using the global positioning system (GPS). 


\begin{tabular}{|c|c|c|}
\hline $\begin{array}{l}\text { AIR SAMPLE } \\
\text { SITE }\end{array}$ & $\begin{array}{l}\text { NORTH LATITUDE } \\
\text { (deg. min. sec.) }\end{array}$ & $\begin{array}{l}\text { WEST LONGITUDE } \\
\text { (deg. min. sec.) }\end{array}$ \\
\hline SITE 1 & $32^{\circ} \quad 22^{\prime} \quad 23.9^{\prime \prime}$ & $\begin{array}{lll}103^{\circ} & 47^{\prime} & 32.0^{\prime \prime}\end{array}$ \\
\hline SITE 2 & $32^{\circ} \quad 22^{\prime} \quad 28.9^{\prime \prime}$ & $103^{\circ} 47^{\prime} 15.8^{\prime \prime}$ \\
\hline SITE 3 & $32^{\circ} .47^{\prime} \quad 53.7^{\prime \prime}$ & $103^{\circ} \quad 47^{\prime} \quad 53.7^{\prime \prime}$ \\
\hline ARTESIA & $32^{\circ} \quad 49^{\prime} 19.9^{\prime \prime}$ & $104^{\circ} \quad 26^{\prime} \quad 42.3^{\prime \prime}$ \\
\hline CARLSBAD & $\begin{array}{lll}32^{\circ} & 25^{\prime} & 31.4^{\prime \prime}\end{array}$ & $104^{\circ} 13^{\prime} 35.3^{\prime \prime}$ \\
\hline HOBBS & $32^{\circ} \quad 42^{\prime} \quad 09.3^{\prime \prime}$ & $103^{\circ} 08^{\prime} \quad 04.3^{\prime \prime}$ \\
\hline LOVING & $32^{\circ} \quad 17^{\prime} \quad 16.1^{\prime \prime}$ & $104^{\circ} 05^{\prime} 50.3^{\prime \prime}$ \\
\hline
\end{tabular}

Gross alpha and gross beta screening of individual LVAS filters conducted prior to 1993 was discontinued and replaced with gamma spectroscopy screening. The gamma spectroscopy methods provide information on specific gamma emitting radionuclides such as ${ }^{241} \mathrm{Am}$ and ${ }^{137} \mathrm{Cs}$. Gross alpha and gross beta measurements exhibit high variability due to fluctuations in radon progeny concentrations, self attenuation and filter attenuation. These concentrations also vary due to atmospheric changes associated with the seasons. Gamma spectroscopy is less sensitive to these sources of variability. A separate report on screening methodology and results of screening will be issued.

Low volume air samplers collect air particulates on $102 \mathrm{~mm}$ (4 in) diameter borosilicate microfiber filters at a nominal rate of $0.23 \mathrm{~m}^{3} / \mathrm{min}\left(8 \mathrm{ft}^{3} / \mathrm{min}\right)$. A typical sampling period lasts for seven days which provides a single filter volume of approximately $2.3 \times 10^{3} \mathrm{~m}^{3}\left(8.1 \times 10^{4} \mathrm{ft}^{3}\right)$. Individual LVAS filters are screened after 24 hours by gamma spectroscopy for possible elevated activity in the ${ }^{137} \mathrm{Cs}$ and ${ }^{241} \mathrm{Am}$ regions of interest. These samples are composited on a quarterly basis by site and analyzed for ${ }^{137} \mathrm{Cs},{ }^{241} \mathrm{Am},{ }^{238} \mathrm{Pu}$ and ${ }^{239+240} \mathrm{Pu}$ activity. The quarterly sample volume is used in the calculation to determine radionuclide activity concentration and total error.

The air sample filter holder is located in an upward facing, non-directional configuration. The filter is protected from rain and snow degradation through the use of a rain shield described by Liu and Pui (1980). Wind tunnel test performed at the University of Minnesota using the rain 
shield design indicate high aspiration efficiency with little dependence on wind speed (Liu and Pui 1980).

\subsection{Water Surveillance}

Groundwater samples are collected from water-bearing zones of the Dewey Lake Redbed Formation, the Culebra dolomite member of the Rustler Formation, and the Capitan Reef Formation. Many of the water samples from these wells are collected by EEG at the same time DOE samples are collected. The latitude and longitude coordinates (degrees, minutes, seconds) as determined by the GPS for each well location are in Table 3.

\section{Table 3. Location of Water Wells Sampled}

\begin{tabular}{|c|c|c|c|c|c|c|}
\hline \multirow{2}{*}{$\begin{array}{c}\text { WELL } \\
\text { NUMBER }\end{array}$} & \multicolumn{3}{|c|}{$\begin{array}{l}\text { NORTH LATITUDE } \\
\text { (deg. min. sec.) }\end{array}$} & \multicolumn{3}{|c|}{$\begin{array}{l}\text { WEST LONGITUDE } \\
\text { (deg. min. sec.) }\end{array}$} \\
\hline & $32^{\circ}$ & $23^{\prime}$ & $03.4^{\prime \prime}$ & $103^{\circ}$ & $48^{\prime}$ & $13.5^{\prime \prime}$ \\
\hline WQSP-5 & $32^{\circ}$ & $21^{\prime}$ & $22.2^{\prime \prime}$ & $103^{\circ}$ & $47^{\prime}$ & $32.9^{\prime \prime}$ \\
\hline WQSP-6 & $32^{\circ}$ & $21^{\prime}$ & 35.1" & $103^{\circ}$ & $48^{\prime}$ & $13.8^{\prime \prime}$ \\
\hline WQSP-6A & $32^{\circ}$ & $21^{\prime}$ & $35.7^{\prime \prime}$ & $103^{\circ}$ & $48^{\prime}$ & 11.3" \\
\hline BARN & $32^{\circ}$ & $19^{\prime}$ & $24.0^{\prime \prime}$ & $103^{\circ}$ & $48^{\prime}$ & $45.0^{\prime \prime}$ \\
\hline RANCH & $32^{\circ}$ & $19^{\prime}$ & $32.2^{\prime \prime}$ & $103^{\circ}$ & $48^{\prime}$ & $32.5^{\prime \prime}$ \\
\hline $\mathrm{H} 2-\mathrm{C}$ & $32^{\circ}$ & $22^{\prime}$ & $04.7^{\prime \prime}$ & $103^{\circ}$ & $48^{\prime}$ & $10.7^{\prime \prime}$ \\
\hline H11-B3 & $32^{\circ}$ & $20^{\circ}$ & $39.6^{\prime \prime}$ & $103^{\circ}$ & $46^{\prime}$ & $27.5^{\prime \prime}$ \\
\hline H14 & $32^{\circ}$ & $21^{\prime}$ & $20.8^{\prime \prime}$ & $103^{\circ}$ & $48^{\prime}$ & 24.1" \\
\hline H3-B3 & $32^{\circ}$ & $21^{\prime}$ & 39.1" & $103^{\circ}$ & $47^{\prime}$ & $31.6^{\prime \prime}$ \\
\hline H4-B & $32^{\circ}$ & $20^{\prime}$ & $20.7 "$ & $103^{\circ}$ & $48^{\prime}$ & $22.2^{\prime \prime}$ \\
\hline H5-B & $32^{\circ}$ & $23^{\prime}$ & $45.0^{\prime \prime}$ & $103^{\circ}$ & $45^{\prime}$ & $26.5^{\prime \prime}$ \\
\hline H6-B & $32^{\circ}$ & $23^{\prime}$ & $53.7 "$ & $103^{\circ}$ & $49^{\prime}$ & $25.0^{\prime \prime}$ \\
\hline H9-B & $32^{\circ}$ & $14^{\prime}$ & $47.0^{\prime \prime}$ & $103^{\circ}$ & $47^{\prime}$ & 24.4" \\
\hline WIPP-19 & $32^{\circ}$ & $22^{\prime}$ & $38.1 "$ & $103^{\circ}$ & $47^{\prime}$ & $30.0^{\prime \prime}$ \\
\hline
\end{tabular}


The radiochemical analysis of ${ }^{241} \mathrm{Am},{ }^{239+240} \mathrm{Pu}$ and ${ }^{238} \mathrm{Pu}$ concentrations in water samples are reported in Tables $\mathrm{C} 1$ through C3 of Appendix C. Samples collected during this report period were not analyzed for ${ }^{137} \mathrm{Cs}$ activity.

Data from water samples collected from the Pecos River in Carlsbad provide a radionuclide baseline and a comparison for similar data from the Pierce Canyon area of the Pecos River about $19 \mathrm{~km}$ (12 mi) downstream from Carlsbad. Mercer (1983) suggests that saturated zones in the Rustler Formation discharge to the Pecos River near Malaga Bend, about a mile upstream of where the river enters Pierce Canyon. Because of the role of the Rustler Formation as a potential hydrologic pathway for radionuclide migration, preoperational data from these regions are important. Radionuclide baseline data are also collected from surface water in Laguna Grande de la Sal which is located $13 \mathrm{~km}$ ( $8 \mathrm{mi}$ ) southwest of the WIPP facility.

The samples from Laguna Grande de la Sal are collected from the eastern perimeter near IMC's No. 5 shaft. The saline lake is in the storm water drainage from the facility and is a discharge point for shallow groundwater in Nash Draw. Because particulates in air emissions from WIPP operations could fall onto the area watershed, water samples are collected from five nearby rain catchment basins used for livestock and game watering.

Table 4 contains the latitude and longitude (degrees, minutes, seconds) of each surface water sampling location as determined by GPS. 
Table 4. Location of Surface Water Samples

\begin{tabular}{lllllll}
\hline $\begin{array}{c}\text { SURFACE WATER } \\
\text { BY (GPS) }\end{array}$ & $\begin{array}{c}\text { NORTH LATITUDE } \\
\text { (deg. min. sec.) }\end{array}$ & \multicolumn{2}{c}{$\begin{array}{c}\text { WEST LONGITUDE } \\
\text { (deg. min. sec.) }\end{array}$} \\
\hline STORM WATER & $32^{\circ}$ & $22^{\prime}$ & $15.7^{\prime \prime}$ & $103^{\circ}$ & $47^{\prime}$ & $43.7^{\prime \prime}$ \\
HILL TANK & $32^{\circ}$ & $22^{\prime}$ & $53.0^{\prime \prime}$ & $103^{\circ}$ & $50^{\prime}$ & $22.4^{\prime \prime}$ \\
INDIAN TANK & $32^{\circ}$ & $17^{\prime}$ & $00.8^{\prime \prime}$ & $103^{\circ}$ & $53^{\prime}$ & $01.2^{\prime \prime}$ \\
LAGUNA GRANDE & $32^{\circ}$ & $19^{\prime}$ & $30.5^{\prime \prime}$ & $103^{\circ}$ & $55^{\prime}$ & $35.4^{\prime \prime}$ \\
NOYA TANK & $32^{\circ}$ & $26^{\prime}$ & $24.3^{\prime \prime}$ & $103^{\circ}$ & $47^{\prime}$ & $39.5^{\prime \prime}$ \\
PECOS CBD & $32^{\circ}$ & $25^{\prime}$ & $27.7^{\prime \prime}$ & $104^{\circ}$ & $13^{\prime}$ & $11.1^{\prime \prime}$ \\
PECOS PC & $32^{\circ}$ & $11^{\prime}$ & $20.4^{\prime \prime}$ & $103^{\circ}$ & $58^{\prime}$ & $38.1^{\prime \prime}$ \\
RED LAKE & $32^{\circ}$ & $27^{\prime}$ & $54.1^{\prime \prime}$ & $103^{\circ}$ & $53^{\prime}$ & $52.2^{\prime \prime}$ \\
RED TANK & $32^{\circ}$ & $22^{\prime}$ & $45.3^{\prime \prime}$ & $103^{\circ}$ & $43^{\prime}$ & $14.8^{\prime \prime}$ \\
\hline
\end{tabular}

Figure 8 shows the relative location of surface water sampling locations. Radiochemical data from surface water samples are presented in Appendix C.

Public drinking water systems used by communities near the WIPP facility are also sampled annually and analyzed to determine ${ }^{241} \mathrm{Am}$, ${ }^{239+240} \mathrm{Pu}$ and ${ }^{238} \mathrm{Pu}$ concentrations. These water systems would not be expected to receive WIPP related contamination under

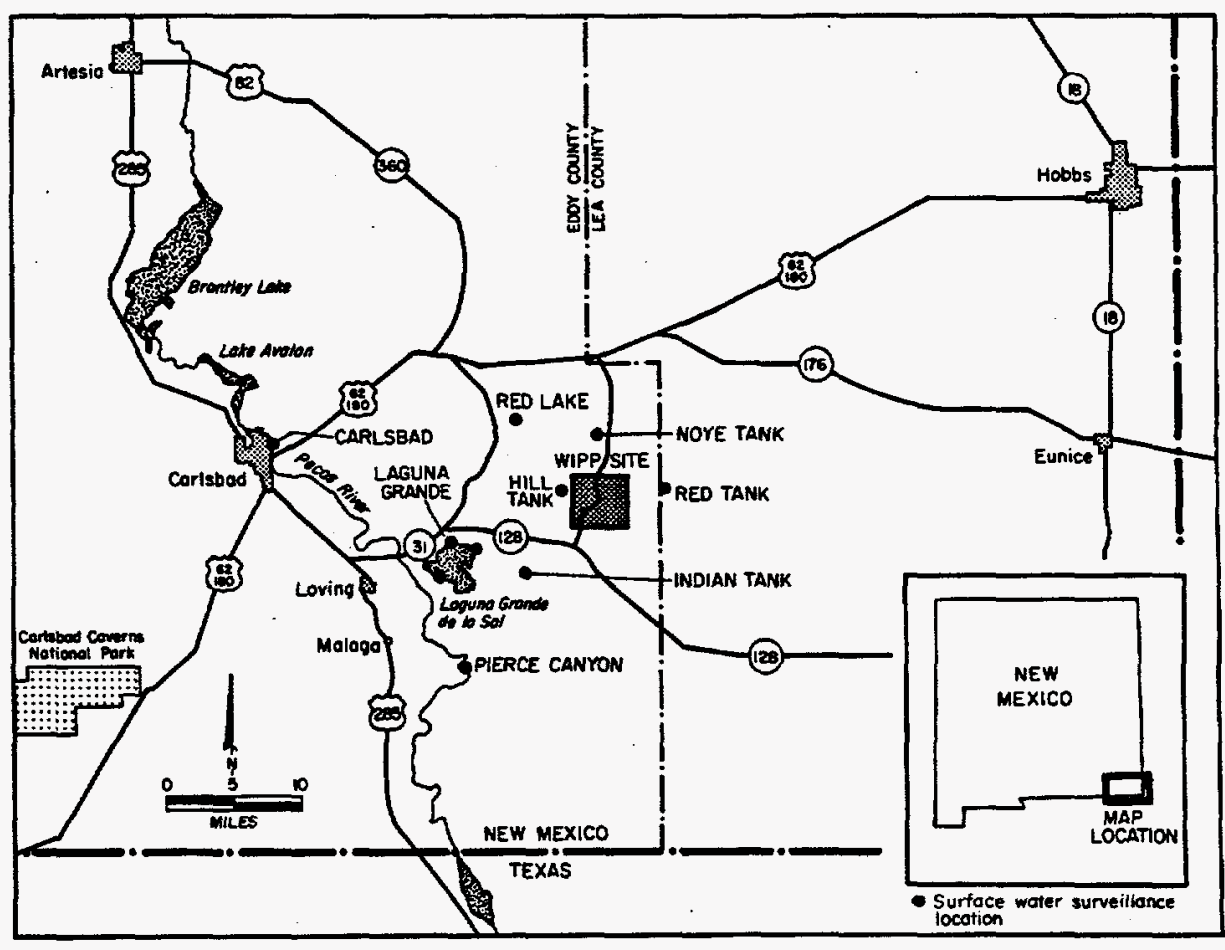

Figure 8. Surface Water Sampling Locations 
presently postulated scenarios in the WIPP Safety Analysis Report (US DOE, WIPP 1997a). However, it is necessary to understand the activity of the radionuclides of interest as a part of the preoperational baseline program.

Data resulting from the analysis of these public water supply systems can be found in Appendix C. Because each systems receives water from various well locations it is not possible to assign a GPS coordinate to a system composite sample.

\subsection{Soil and Sediment Surveillance}

Soil and sediment in the vicinity of WIPP contain a record of deposited radioactive fallout from past atmospheric nuclear weapons testing, as well as surface contamination from Project Gnome. Cs-137 was identified in the area of the Gnome site during an aerial gamma survey for the WIPP baseline studies (Berry 1989). It is believed that a certain amount of this deposited fallout may become re-suspended in air under certain atmospheric and soil conditions. Because WIPP TRU waste contain some of the fission products found in fallout, these data are an important component of the preoperational environmental baseline for WIPP.

During 1994 EEG conducted a detailed study of the radionuclide concentrations in a few locations at the Gnome site (Kenney et al. 1995). The EEG study produced detailed maps of areas which exhibit elevated gamma activity that resulted from fission products venting from the Gnome access shaft. Gamma fields associated with the subsequent shallow burial of radioactive material were also identified. Selected soil samples from the ground surface at Gnome were radiochemically analyzed for ${ }^{241} \mathrm{Am},{ }^{238} \mathrm{Pu}$ and ${ }^{239+240} \mathrm{Pu}$. Analytical data from soil samples obtained for the Gnome study are not repeated in this report.

\subsection{Statistical Methods}

In the EEG laboratory, individual air filter samples are screened using gamma spectroscopy to determine the presence or absence of ${ }^{241} \mathrm{Am}$ and ${ }^{137} \mathrm{Cs}$. To provide an early estimate of possible contamination individual FAS filters are screened after a minimum decay of 5 hours while LVAS 
filters are counted after a minimum decay of 24 hours which allows time for the decay of some radon progeny. The gamma system consists of a reverse-electrode closed-end coaxial germanium detector enclosed in a 4 inch thick lead shield and a multichannel analyzer. Spectral files for each filter are analyzed for elevated levels in the ${ }^{241} \mathrm{Am}$ and ${ }^{137} \mathrm{Cs}$ regions. Regions of interest used in the screening methodology were set using data collected from standard sources traceable to the NIST.

Filters composited by calendar quarter for each location were analyzed for ${ }^{241} \mathrm{Am},{ }^{238} \mathrm{Pu}$, and ${ }^{239+240} \mathrm{Pu}$ using destructive radiochemistry followed by alpha spectroscopy. Analysis of transuranics was accomplished through the use of a recovery monitor, i.e., an accurately known amount of ${ }^{242} \mathrm{Pu}$ or ${ }^{243} \mathrm{Am}$, as appropriate, added to each sample prior to destructive analysis, the measurement of which allowed correction of each sample for both counting efficiency and chemical recovery. The correction factor $(\mathrm{K})$ in the equation below has units of measuredcounts-per-second per becquerel (Bq).

The ${ }^{137} \mathrm{Cs}$ composite activity was determined using gamma spectroscopy before chemical destruction. Radiochemical analysis of environmental samples, presented in Appendix B, are required to quantify specific radionuclides common to the preoperational WIPP environment and WIPP waste. For reasons discussed below, it was desirable to analyze a number of "procedure" or "matrix" blanks along with the samples. These were unused filter composites or liter samples of deionized water free of the target nuclides (i.e., free of ${ }^{238} \mathrm{Pu},{ }^{239 / 240} \mathrm{Pu},{ }^{241} \mathrm{Am}$, and ${ }^{137} \mathrm{Cs}$ ). These blanks were carried through the identical processing as the samples. The blank results appear later in this section and provided a means of correcting the sample results for any activity introduced solely as a result of the chemical processing, or simply from the matrix itself in the case of ${ }^{137} \mathrm{Cs}$.

Analysis of the transuranics was done by alpha spectroscopy using four separate spectrometers. As samples were counted, the four detectors became contaminated at very low but highly variable levels, principally by recoil from trace contaminants in the samples which emitted high energy alpha particles. This process is almost unavoidable in alpha spectroscopy and is a principle cause for limited useful lifetimes of the detectors. These recoil contaminants generally 
appeared as high energy peaks in the alpha spectra, well above the regions of interest (ROI) for the target nuclides, but inevitably some counts from the high energy regions spilled down into the target ROIs, with the result that each detector gradually acquired it's own unique background activity in the ROIs.

Because it was possible to analyze only a limited number of blanks, all blanks were averaged for a given matrix/nuclide combination without regard to which detector was used for the blank analysis. The average was then used to correct individual samples. Because the detector backgrounds were variable, it was necessary to subtract detector backgrounds from the individual blanks before averaging. Failure to do so would have resulted in subtracting an "average" detector background from the sample spectrum, instead of the correct detector background for that sample. Therefore, calculation of sample activities involved subtracting detector backgrounds from both blanks and samples. Only then were sample activities corrected for the blank contribution.

The activity concentration of the transuranics was calculated by the following equation:

$$
\text { Net Activity Concentration }\left(B q / m^{3} \text { or } B q / l\right)=\frac{\frac{c p s_{\text {samp }}-c p s_{b k g l}}{K_{1}}-\frac{c p s_{b l a n k}-c p s_{b k g 2}}{K_{2}}}{V}
$$

where

$\mathrm{cps}_{\mathrm{x}}=\mathrm{ROI}$ counts-per-second for the sample, its detector background (bkg1), the blank, and its detector background (bkg2),

$\mathrm{V}=$ the sample volume $\left(\mathrm{m}^{3}\right.$ or $\left.\mathrm{l}\right)$

$\mathrm{K}_{\mathrm{n}}=$ correction factor described above, based on counting the "spike" activity for the sample measurement $\left(\mathrm{K}_{1}\right)$ and the blank measurement $\left(\mathrm{K}_{2}\right)$ and is equal to: 


$$
\frac{c p s_{\text {spike }}-c p s_{b k g}}{B q(\text { spike activity) }}
$$

NOTE that the second term in the numerator of equation (1) is an average of all applicable blank measurements.

The total propagated uncertainty (TPU) in the Appendices tables is the quadratic sum of all random and systematic errors for all measured quantities in the final result, multiplied by a coverage factor to achieve approximately $95 \%$ confidence. That is:

$$
T P U=2 \times \sqrt{e_{1}^{2}+e_{2}^{2}+\ldots .+e_{n}^{2}}
$$

In practice, the different error terms are expressed in different units and must be converted to fractions or percentages of their source terms before they can be used in the equation. For the transuranics analyses, the sources of the error terms were as follows:

Counting errors (approximated by $\sqrt{N}$ divided by $\mathrm{T}$, where $\mathrm{N}$ is the accumulated counts in the ROI in the counting interval, $\mathrm{T}$ )

4 terms $\left(e_{1}\right.$ through $e_{4}$ ) expressing cps uncertainty for the target nuclide and recovery monitor nuclide, and the appropriate detector background counts.

\section{Calibration factor errors}

4 terms ( $e_{5}$ through $e_{8}$ ) expressing the published uncertainty in the certified value of the activity concentration of the source solution used to prepare the recovery monitor solution, and the uncertainty in the weights obtained in preparing the recovery monitor solution and adding it to the sample or blank. 
Blank correction error

1 term $\left(e_{9}\right)$ expressing the 1- $\sigma$ standard deviation of the mean of the appropriate average blank value used to correct the sample data.

\section{Volume errors}

1 term $\left(e_{10}\right)$ expressing the uncertainty in the sample volume.

The factor 2 in the equation (3) is to achieve an approximate $95 \%$ confidence level for the TPU.

The ${ }^{137} \mathrm{Cs}$ determinations were done non-destructively with the result that no chemical recovery monitor was used. For the calculation of the activity concentration of the ${ }^{137} \mathrm{Cs}$, Equation (1) was modified as:

Net Activity Concentration $\left(B q / m^{3}\right)=\frac{\frac{c p s_{\text {samp }}-c p s_{\text {continuxml }}}{\epsilon I}-\frac{c p s_{\text {blank }}-c p s_{\text {continuum } 2}}{\epsilon I}}{V}$

where

$\mathrm{cps}_{\mathrm{x}}=\mathrm{ROI}$ counts-per-second for the sample, its gamma continuum (continuum1 discussed below), the blank, and its gamma continuum (continuum2),

$\epsilon=$ the mean gamma-counting efficiency, in units of counts $\sec ^{-1}$ per photon $\sec ^{-1}$ emitted from the source for the appropriate counting geometry,

$\mathrm{I}=$ photon intensity, in units of photons $\mathrm{sec}^{-1}$ per disintegration $\mathrm{sec}^{-1}$ (or $\mathrm{Bq}$ ), and

$\mathrm{V}=$ sample volume $\left(\mathrm{m}^{3}\right)$ or $(1)$ 
Note that the combination $\in \mathrm{I}$ is the equivalent of (and has the same units, $\mathrm{cps} \mathrm{Bq}^{-1}$, as) the $\mathrm{K}$ factor in equation (1).

The TPU calculation for the ${ }^{137} \mathrm{Cs}$ measurements is identical to equation (3) except that the detector background errors of equation (3) are replaced with the uncertainty in the calculated continuum and the four terms of the calibration factor error are:

1 term expressing the uncertainty in the certified value of the photon-emission rate of the

${ }^{137} \mathrm{Cs}$ standard in units of photons-per-second from ${ }^{137 \mathrm{~m}} \mathrm{Ba}$,

1 term expressing the uncertainty in the intensity of the $662-\mathrm{keV}$ gamma line of ${ }^{137 \mathrm{~m}} \mathrm{Ba}$, in units of ${ }^{137 \mathrm{~m}} \mathrm{Ba}$ photon $\sec ^{-1}$ per ${ }^{137} \mathrm{Cs}$ disintegration $\mathrm{sec}^{-1}$, available in NCRP (58),

1 term expressing the standard deviation of multiple measurements of $\epsilon$, and

1 term expressing the uncertainty in the decay correction, if applicable.

As before, the uncertainties are expressed as fractions or percentages to account for different units. The gamma continuum under the $662-\mathrm{keV}$ peak ROI is calculated by linear interpolation between the 4 channels immediately above and the 4 channels immediately below the ROI.

Calculation of the MDA is based upon the method found in ANSI N 13.30, section 3.4.1. The MDA is a measure of the variance $\left(\mathrm{S}_{\mathrm{b}}\right)$ of the analytical process. If the variance is based solely on the observed counts from a detector with the same blank (or no sample blank), then the $S_{b}$ may be underestimated. A better estimate of $S_{b}$ can be made by routine analysis of the environmental matrix devoid of the radioactivity of interest (i.e., uncontaminated air sample filters or distilled water). Air filter and water sample blanks are routinely analyzed along with environmental samples. The resulting blank data are used to calculate the MDAs and MDCs shown in Tables 5,6 and 7. The derived variance is more indicative of the total variance of the analytical measurement process. Control charting of such data can show when spurious counts 
appear in a matrix blank perhaps from cross-contamination from glassware or co-contamination of reagents (Rodgers and Kenney 1997). The MDA was calculated using equation (5):

$$
M D A=\frac{4.65 \times S_{b}}{K T}
$$

Where:

$$
\begin{aligned}
& \mathrm{MDA}=\text { Minimum Detectable Activity (Bq/composite) } \\
& 4.65=\text { Constant for estimation of } 95 \% \text { confidence } \\
& \mathrm{S}_{\mathrm{b}}=\text { Standard deviation of activity in a group of appropriate procedure matrix blanks } \\
& \mathrm{K}=\text { calibration constant containing the estimated yield and efficiency (counts-per- } \\
& \text { seconds/Bq) } \\
& \mathrm{T}=\text { count time (seconds) }
\end{aligned}
$$

Thus the calculation of minimum detectable concentration can be expressed as follows:

$$
M D C=M D A / S A M P L E \text { VOLUME }
$$

Where:

$$
\begin{aligned}
& \mathrm{MDC}=\text { Minium Detectable Concentration }(\mathrm{Bq} / \text { volume }) \\
& \mathrm{MDA}=\text { Minimum Detectable Activity }(\mathrm{Bq} / \mathrm{composite}) \\
& \text { Sample Volume }=\text { The average volume }\left(\mathrm{m}^{3} \text { or } 1\right) \text { in a series of samples }
\end{aligned}
$$

The major objective of the EEG's preoperational environmental surveillance program is to measure the radionuclide concentrations in environmental samples from the vicinity of the WIPP facility. EEG reports all environmental radionuclide concentrations as values, including values less than the MDC or less than zero as suggested in NRC Regulatory Guide 4.14 (US NRC 
1980). The MDA is an estimate of the sensitivity of a process and should not be compared to any single result.

However, the level above which activity is defined as being present is not the MDC. The ACTL defined by Corley et al. (1981) is applied to determine if a single result is statistically different from the established baseline concentration at the $97.7^{\text {th }}$ quantile (i.e., $97.7 \%$ confidence level). When an ACTL is exceeded in the EEG laboratory an internal investigation into the cause begins. The investigation includes but is not limited to verification of calculations, counting instrument operation, and contamination of glassware. Should the investigation fail to indicate a probable cause, results obtained by WID for similar samples is reviewed. The ACTL, for a given radionuclide concentration can be defined as:

$$
A C T L=M B L+Q_{97.7}
$$

Where:

$\operatorname{ACTL}(\mathrm{Bq} /$ sample composite $)=$ the "action level" for a specific radionuclide

$\operatorname{MBL}(\mathrm{Bq} / \mathrm{sample}$ composite $)=$ the mean preoperational baseline activity

Q97.7 = the $97.7 \%$ quantile for normally distributed data which can be estimated as $2 S_{b}$, where $S_{b}$ is the standard deviation of the preoperational data.

The MDA, MDC and ACTL values for the EEG methodologies are found in Tables 5, 6 and 7. Each of three matrix types are shown, LVAS filters, FAS filters and water. 
Table 5. FAS Matrix Blank Data

\begin{tabular}{cccccc}
\hline Radionuclide & $\begin{array}{c}\text { No. of } \\
\text { Blanks }\end{array}$ & $\begin{array}{c}\text { Avg. Activity } \\
\text { (Bq/Composite) }\end{array}$ & $\begin{array}{c}\text { ACTL } \\
(\mathrm{Bq} / \text { Composite) }\end{array}$ & $\begin{array}{c}\mathrm{MDA} \\
(\mathrm{Bq} / \text { Composite) }\end{array}$ & $\begin{array}{c}\mathrm{MDC} \\
\left(\mathrm{Bq} / \mathrm{m}^{3}\right)\end{array}$ \\
\hline${ }^{241} \mathrm{Am}$ & 8 & $3.7 \mathrm{E}^{-4}$ & $2.61 \mathrm{E}^{-3}$ & $1.3 \mathrm{E}^{-3}$ & $2.4 \mathrm{E}^{-7}$ \\
${ }^{239+240} \mathrm{Pu}$ & 8 & $1.3 \mathrm{E}^{-4}$ & $1.51 \mathrm{E}^{-3}$ & $1.3 \mathrm{E}^{-3}$ & $2.4 \mathrm{E}^{-3}$ \\
${ }^{238} \mathrm{Pu}$ & 8 & $2.2 \mathrm{E}^{-5}$ & $1.53 \mathrm{E}^{-3}$ & $1.3 \mathrm{E}^{-3}$ & $2.3 \mathrm{E}^{-7}$ \\
${ }^{137} \mathrm{Cs}$ & 11 & $5.0 \mathrm{E}^{-3}$ & $3.90 \mathrm{E}^{-2}$ & $1.7 \mathrm{E}^{-1}$ & $3.1 \mathrm{E}^{-5}$ \\
\hline
\end{tabular}

Table 6. LVAS Matrix Blank Data

\begin{tabular}{cccccc} 
Radionuclide & $\begin{array}{c}\text { No. of } \\
\text { Blanks }\end{array}$ & $\begin{array}{c}\text { Avg. Activity } \\
(\mathrm{Bq} / \text { Composite) }\end{array}$ & $\begin{array}{c}\mathrm{ACTL} \\
(\mathrm{Bq} / \text { Composite) }\end{array}$ & $\begin{array}{c}\mathrm{MDA} \\
(\mathrm{Bq} / \text { Composite) }\end{array}$ & $\begin{array}{c}\mathrm{MDC} \\
\left(\mathrm{Bq} / \mathrm{m}^{3}\right)\end{array}$ \\
\hline${ }^{241} \mathrm{Am}$ & 9 & $5.3 \mathrm{E}^{-4}$ & $4.6 \mathrm{E}^{-3}$ & $2.4 \mathrm{E}^{-3}$ & $9.6 \mathrm{E}^{-8}$ \\
${ }^{239+240} \mathrm{Pu}$ & 8 & $2.5 \mathrm{E}^{-4}$ & $3.5 \mathrm{E}^{-3}$ & $7.4 \mathrm{E}^{-4}$ & $3.0 \mathrm{E}^{-8}$ \\
${ }^{238} \mathrm{Pu}$ & 10 & $7.3 \mathrm{E}^{-4}$ & $3.0 \mathrm{E}^{-3}$ & $2.7 \mathrm{E}^{-3}$ & $1.1 \mathrm{E}^{-7}$ \\
${ }^{137} \mathrm{Cs}$ & 10 & $-7.7 \mathrm{E}^{-3}$ & $7.6 \mathrm{E}^{-2}$ & $1.5 \mathrm{E}^{-1}$ & $6.0 \mathrm{E}^{-6}$ \\
\hline
\end{tabular}

Table 7. Water Matrix Blank Data

\begin{tabular}{cccccc} 
Radionuclide & $\begin{array}{c}\text { Number of } \\
\text { Blanks }\end{array}$ & $\begin{array}{c}\text { Avg. Activity } \\
(\mathrm{Bq})\end{array}$ & $\begin{array}{c}\mathrm{ACTL} \\
(\mathrm{Bq})\end{array}$ & $\begin{array}{c}\mathrm{MDA} \\
(\mathrm{Bq})\end{array}$ & $\begin{array}{c}\mathrm{MDC} \\
(\mathrm{Bq} / 1)\end{array}$ \\
\hline${ }^{241} \mathrm{Am}$ & 10 & $7.8 \mathrm{E}^{-4}$ & $1.7 \mathrm{E}^{-3}$ & $2.0 \mathrm{E}^{-3}$ & $2.0 \mathrm{E}^{-3}$ \\
${ }^{239+240} \mathrm{Pu}$ & 13 & $4.0 \mathrm{E}^{-4}$ & $1.2 \mathrm{E}^{-3}$ & $3.0 \mathrm{E}^{-3}$ & $3.0 \mathrm{E}^{-3}$ \\
${ }^{238} \mathrm{Pu}$ & 13 & $3.7 \mathrm{E}^{-4}$ & $1.7 \mathrm{E}^{-3}$ & $3.1 \mathrm{E}^{-3}$ & $3.1 \mathrm{E}^{-3}$ \\
\hline
\end{tabular}




\subsection{DISCUSSION OF FINDINGS}

\subsection{Air Data}

Ingestion and inhalation of transuranic radionuclides pose the greatest potential health risk from a regulatory perspective. Consequently, environmental release limits are extremely low, and measuring chronic radioactive releases from the underground repository provides the greatest monitoring challenge.

To determine if the EEG sampling and radiochemical processes are sensitive enough to measure chronic releases before they exceed regulatory limits, EEG used a screening calculation endorsed by the National Council on Radiation Protection and Measurements (NCRP 1996). The simplified method, "Screening Models for Releases of Radionuclides to Atmosphere, Surface Water and Ground" (NCRP 1996), provides very conservative limits for assessing environmental releases. If the regulatory limits were approached, then immediate investigative action would be necessary. Because WIPP does not expect to routinely release radioactivity, any positive measurement outside normal variance warrants additional analysis. The NCRP report provides a series of simple screening techniques that can be used to demonstrate the capability of a measurement system to measure a dose standard. If compliance with regulatory limits can be demonstrated using these screening models, then more sophisticated modeling techniques are not necessary. The NCRP report emphasizes that "doses" estimated by the model are strictly for comparison with a environmental standard and are not intended to represent estimates of actual doses to individuals.

The NCRP report provides three levels of screening. Level I, which was applied to data contained in this report, is the most conservative (i.e., would tend to overestimate dose), Level II is less conservative and Level III is the least conservative. The suggestion is to use the most conservative level and resort to less conservative as needed.

Each radionuclide concentration used in the NCRP screening technique was assumed to be continuously released at the MDC for one year. The total underground exhaust ventilation 
volume was based upon a continuous flow rate of $12,000 \mathrm{~m} / \mathrm{min}(425,000 \mathrm{scfm})$. The MDC values for each radionuclide measured in the FAS matrix blanks are contained in Table 5. The MDC values for FAS filters from Station A were applied to the NCRP Screening Level I. Table 8 contains NCRP Screening Level I results and the regulatory dose limit. The derived dose from underground air emissions from Station $\mathrm{A}$ was found to be $1.3 \times 10^{-7} \mathrm{~Sv} / \mathrm{y}$. The EEG effluent air monitoring program will detect doses approximately 1000 times below the regulatory limit of 1.0 $x 10^{-4} \mathrm{~Sv} / \mathrm{y}(10 \mathrm{mrem} / \mathrm{y})$ in 40 CFR $61 \mathrm{Subpart} H$ or $2.5 \times 10^{-4} \mathrm{~Sv} / \mathrm{y}(25 \mathrm{mrem} / \mathrm{y})$ in 40 CFR 191 Subpart A.

\section{Table 8. Effluent Air Dose Estimates (NCRP \#123 Level I)}

\begin{tabular}{|c|c|c|c|}
\hline & \multicolumn{3}{|c|}{ Radionuclide } \\
\hline & ${ }^{241} \mathrm{Am}$ & ${ }^{239+240} \mathrm{Pu}$ & ${ }^{238} \mathrm{Pu}$ \\
\hline FAS MDA (Bq/QTR) & $1.3 \mathrm{E}^{-3}$ & $1.3 \mathrm{E}^{-3}$ & $1.3 \mathrm{E}^{-3}$ \\
\hline $\mathrm{Q}(\mathrm{Bq} / \mathrm{s})$ & $3.5 \mathrm{E}^{-5}$ & $3.5 \mathrm{E}^{-5}$ & $3.4 \mathrm{E}^{-5}$ \\
\hline $\mathrm{V}\left(\mathrm{m}^{3} / \mathrm{s}\right)$ & $2.0 \mathrm{E}^{+2}$ & $2.0 \mathrm{E}^{+2}$ & $2.0 \mathrm{E}^{+2}$ \\
\hline $\mathrm{C}_{e}(\mathrm{Q} / \mathrm{V})$ & $1.8 \mathrm{E}^{-7}$ & $1.8 \mathrm{E}^{-7}$ & $1.7 \mathrm{E}^{-7}$ \\
\hline $\mathrm{C}\left(\mathrm{Bq} / \mathrm{m}^{3}\right)$ & $4.4 \mathrm{E}^{-8}$ & $4.4 \mathrm{E}^{-8}$ & $4.2 \mathrm{E}^{-8}$ \\
\hline $\mathrm{SF}\left(\mathrm{Sv} / \mathrm{Bq} / \mathrm{m}^{3}\right)$ & 1.00 & 1.00 & 0.89 \\
\hline $\mathrm{SV}(\mathrm{Sy} / \mathrm{y})$ & $4.4 \mathrm{E}^{-8}$ & $4.4 \mathrm{E}^{-8}$ & $3.7 \mathrm{E}^{-8}$ \\
\hline \multicolumn{4}{|c|}{ TOTAL ${ }^{241} \mathrm{Am},{ }^{239+240} \mathrm{Pu},{ }^{238} \mathrm{Pu}(\mathrm{Sv} / \mathrm{y})=1.3 \mathrm{E}^{-7}$} \\
\hline \multicolumn{4}{|c|}{ LIMIT $\left(\right.$ Sv/y) $=1.0 \mathrm{E}^{-4}(40$ CFR 61 SUBPART H) } \\
\hline \multicolumn{4}{|c|}{ LIMIT $\left(\right.$ Sv/y) $=2.5 E^{-4}(40$ CFR 191 SUBPART A) } \\
\hline
\end{tabular}

Elements of Table 8 are as follow:

$\mathrm{Q}(\mathrm{Bq} / \mathrm{s})=$ The release rate of the radionuclide entered above is the MDA of the radionuclide (Bq/quarter composite times 4 ) divided by the number of seconds per year which corrects for exhaust volume/sample volume.

$\mathrm{V}\left(\mathrm{m}^{3} / \mathrm{s}\right)=$ The volumetric flow rate of the exhaust vent $\left(\mathrm{m}^{3} / \mathrm{s}\right)$.

$\mathrm{C}_{\mathrm{e}}(\mathrm{Q} / \mathrm{V})=$ The radionuclide concentration in the exhaust air. The release rate is activity $(\mathrm{Bq})$ divided by volumetric air flow $\left(\mathrm{m}^{3}\right)$. 
$\mathrm{C}\left(\mathrm{Bq} / \mathrm{m}^{3}\right)=\mathrm{A}$ factor used for assumption that the wind blows in the direction of a potentially exposed person $25 \%$ of the time.

$\mathrm{SF}\left(\mathrm{Sv} / \mathrm{Bq} / \mathrm{m}^{3}\right)=$ The Screening Factor which is selected from Table 1.1 of NCRP \#123 for the specific radionuclide. The value of SF includes all significant potential pathways of exposure.

SV $(\mathrm{Sv} / \mathrm{y})=$ Screening value which is the atmospheric concentration (C) multiplied by the screening factor (SF).

Total $(\mathrm{Sv} / \mathrm{y})=$ The sum of all radionuclides measured $(\mathrm{SV})$

$40 \mathrm{CFR} 61 \mathrm{H}(\mathrm{Sv} / \mathrm{y})=$ The regulatory dose limit of $10 \mathrm{mrem} / \mathrm{year}\left(1.0 \times 10^{-4} \mathrm{~Sv} / \mathrm{y}\right)$.

The EEG's reported

radionuclide air

concentrations were next

compared to those

concentrations published by

EPA and LANL for sites in

New Mexico. The

concentrations given in

Table 9 and shown in Figure

9 are averages of the

analytical results from

ambient air samples

collected in Santa Fe, New

Mexico by EPA, from Los
Am-241, Pu-239, Pu-238 IN AIR

EEG, LANL AND EPA 1993-1995

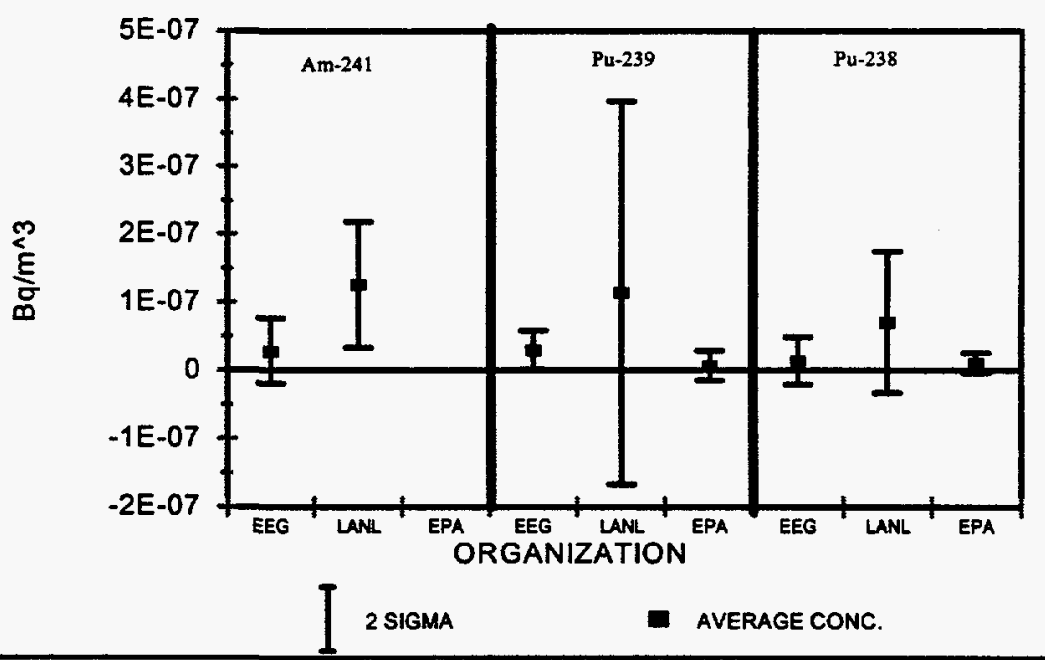

Figure 9. Comparison of EEG, LANL and EPA Average Actinide Concentration Data From Samples Collected in New Mexico from 1993-1995

Alamos by LANL and near the WIPP site by EEG. Average concentrations measured by the various organizations appear to agree, within the uncertainties given. 
Table 9. Average Air Concentration of Actinides in New Mexico

\begin{tabular}{lcccccc}
\hline \multirow{2}{*}{ Actinide } & \multicolumn{2}{c}{$\mathrm{EEG}^{\mathrm{a}}$} & \multicolumn{2}{c}{ LANL $^{\mathrm{b}}$} & \multicolumn{2}{c}{$\mathrm{EPA}^{\mathrm{c}}$} \\
\cline { 2 - 7 } & $\begin{array}{c}\text { Activity } \\
\left(\mathrm{Bq} / \mathrm{m}^{3}\right)\end{array}$ & $\begin{array}{c}2 \text { Sigma } \\
\left(\mathrm{Bq} / \mathrm{m}^{3}\right)\end{array}$ & $\begin{array}{l}\text { Activity } \\
\left(\mathrm{Bq} / \mathrm{m}^{3}\right)\end{array}$ & $\begin{array}{c}2 \text { Sigma } \\
\left(\mathrm{Bq} / \mathrm{m}^{3}\right)\end{array}$ & $\begin{array}{c}\text { Activity } \\
\left(\mathrm{Bq} / \mathrm{m}^{3}\right)\end{array}$ & $\begin{array}{c}2 \text { Sigma } \\
\left(\mathrm{Bq} / \mathrm{m}^{3}\right)\end{array}$ \\
\hline${ }^{241} \mathrm{Am}$ & $2.9 \mathrm{E}^{-8}$ & $4.8 \mathrm{E}^{-8}$ & $1.3 \mathrm{E}^{-7}$ & $9.3 \mathrm{E}^{-8}$ & $\mathrm{~N} / \mathrm{A}$ & $\mathrm{N} / \mathrm{A}$ \\
${ }^{239+240} \mathrm{Pu}$ & $3.0 \mathrm{E}^{-8}$ & $2.8 \mathrm{E}^{-8}$ & $1.1 \mathrm{E}^{-7}$ & $2.8 \mathrm{E}^{-7}$ & $7.4 \mathrm{E}^{-9}$ & $2.2 \mathrm{E}^{-8}$ \\
${ }^{238} \mathrm{Pu}$ & $1.4 \mathrm{E}^{-8}$ & $3.5 \mathrm{E}^{-8}$ & $7.0 \mathrm{E}^{-8}$ & $1.0 \mathrm{E}^{-7}$ & $1.1 \mathrm{E}^{-8}$ & $1.5 \mathrm{E}^{-8}$ \\
\hline
\end{tabular}

a Data is average of all LVAS results from ambient air collected by EEG during 1993 through 1995 (see Appendix B).

b Data is average result of LANL air samples from Santa Fe, Espanola and Pojoaque, New Mexico during CY 1993, 1994 and 1995 (LANL 1995, 1996a, 1996b).

' Data is average results of air samples collected in Santa Fe, New Mexico and analyzed by EPA during 1993, 1994 and the first six months of 1995 (US EPA 1994, 1996a, 1996b, 1997a, 1997b).

Analytical radiochemistry data and graphical representations of quarterly LVAS filter data obtained from composites of each site are contained in Tables B-1 through B-85 of Appendix B. There appears to be a negative bias in the ${ }^{239} \mathrm{Pu}$ and ${ }^{240} \mathrm{Pu}$ concentrations shown in Figure $\mathrm{C} 5$ and Table C5 of Appendix C. The causes of this bias are under investigation.

\subsection{Water Data}

The NCRP screening methodology for surface water effluent was also applied to analytical results from storm water effluent samples. Specific radionuclide MDCs were used as the source term $\left(\mathrm{Bq} / \mathrm{m}^{3}\right)$ for ${ }^{241} \mathrm{Am},{ }^{239+240} \mathrm{Pu}$, and ${ }^{238} \mathrm{Pu}$. The calculation assumed that all WIPP storm water effluent contained ${ }^{241} \mathrm{Am},{ }^{239+240} \mathrm{Pu}$, and ${ }^{238} \mathrm{Pu}$ at concentrations equal to the EEG's MDAs. The NCRP screening Level I for surface water was calculated using the following data:

$\mathrm{C}_{\mathrm{o}}\left(\mathrm{Bq} / \mathrm{m}^{3}\right)=$ The $\mathrm{Bq} / \mathrm{m}^{3}$ value was the $\mathrm{MDA}$ for the radionuclide $(\mathrm{Bq} / \mathrm{l})$ times 1000 to obtain $\mathrm{Bq} / \mathrm{m}^{3}$.

$\mathrm{SF}\left(\mathrm{Sv} / \mathrm{Bq} / \mathrm{m}^{3}\right)=$ The screening factors (level I) were chosen from NCRP No. 123 , table 2.1 for each radionuclide in freshwater. 
$\mathrm{SV}(\mathrm{Sv})=$ The screening value is the product of the annual average concentration and the screening factor.

Total $(\mathrm{Sv})=$ The sum of all the various radionuclide screening values.

Limiting Value $(\mathrm{Sv})=$ The regulatory limit used was $2.5 \times 10^{-4} \mathrm{~Sv} / \mathrm{y}$ contained in 40 CFR 191A.

Table 10 contains the results of calculations using the NCRP screening level I for surface water. Clearly, the EEG sampling and analytical methodology is capable of measuring actinides in water that would produce a dose of $1.4 \times 10^{-5} \mathrm{~Sv} / \mathrm{y}$ which is about 10 times below the regulatory limit of $2.5 \times 10^{-4} \mathrm{~Sv} / \mathrm{y}$ specified in 40 CFR 191 Subpart A.

Table 10. Surface Water Dose Estimates (NCRP \#123 Level I)

\begin{tabular}{cccc}
\hline & \multicolumn{3}{c}{ Radionuclide } \\
& ${ }^{241} \mathrm{Am}$ & ${ }^{239+240} \mathrm{Pu}$ & ${ }^{238} \mathrm{Pu}$ \\
\hline $\mathrm{Co}\left(\mathrm{Bq} / \mathrm{m}^{3}\right)$ & $2.0 \mathrm{E}^{0}$ & $3.0 \mathrm{E}^{0}$ & $3.1 \mathrm{E}^{0}$ \\
$\mathrm{SF}\left(\mathrm{Sv}\right.$ per Bq$\left./ \mathrm{m}^{3}\right)$ & $2.0 \mathrm{E}^{-6}$ & $1.7 \mathrm{E}^{-6}$ & $1.5 \mathrm{E}^{-6}$ \\
$\mathrm{SV}(\mathrm{Sy} / \mathrm{y})$ & $4.0 \mathrm{E}^{-6}$ & $6.0 \mathrm{E}^{-6}$ & $6.2 \mathrm{E}^{-6}$ \\
TOTAL ${ }^{241} \mathbf{A m},{ }^{239+240} \mathbf{P u},{ }^{238} \mathbf{P u}(\mathrm{Sv} / \mathrm{y})=\mathbf{1 . 4 \mathrm { E } ^ { - 5 }}$ \\
REG. LIMIT (Sv/y) $=\mathbf{2 . 5 E ^ { - 4 }}(\mathbf{4 0 ~ C F R ~ 1 9 1 ~ A ) ~}$ \\
\hline
\end{tabular}

Radiochemistry data from water samples are contained in Tables C1 through C3 of Appendix C. The apparently high ${ }^{238} \mathrm{Pu}$ concentration $\left(2.2 \times 10^{3} \mathrm{~Bq} / \mathrm{l}\right)$ in the sample collected from the Otis water supply system on April 3, 1995, was traced to probable cross-contamination in the lab. An apparent negative bias in the ${ }^{239} \mathrm{Pu}$ results for surface waters remains unresolved, but will continue to be monitored in future analyses. The average ${ }^{239} \mathrm{Pu}$ concentration of surface water 
samples collected between 1993 and 1995 was $-3.9 \times 10^{-4} \mathrm{~Bq} / \mathrm{l}$. In any case, the magnitude of the bias is much less than the MDC for this analysis and is not considered significant.

Sewage effluent receives only sanitary waste water. Fire water that may be used in the facility is not discharged to the sanitary sewer system. The possibility of radioactive contamination of the total retention sewage lagoons is minimal. For these reasons the EEG does not monitor the sewage lagoon system for actinides.

\subsection{Soil and Sediment Data}

Data obtained from analysis of soil samples collected in 1994 can be found in EEG-58 (Kenney et al. 1995). Analysis of soil samples taken during this study revealed the presence of heterogeneously distributed transuranic radionuclides $\left({ }^{238} \mathrm{Pu},{ }^{239+240} \mathrm{Pu}\right.$ and $\left.{ }^{241} \mathrm{Am}\right)$ at concentrations well above MDC. The heterogeneously distributed radioactivity within the samples indicates the contamination was from nuclear weapons testing. The EEG used a combination of traditional and state-of-the-art radiological survey techniques, otherwise the very low level contamination would have been difficult, if not impossible, to find. The EEG methods were found to be much more sensitive than traditional methods.

\subsection{QUALITY ASSURANCE}

The quality assurance program (QAP) under which the data in this report was gathered, analyzed, and presented is described in the EEG QAPP, "Quality Assurance Program Plan for the Environmental Evaluation Group's Environmental Surveillance of the WIPP Project". The EEG QAPP was originally developed using guidance from the EPA Interim Guidelines and Specifications for Preparing Quality Assurance Program Plans, QAMS-005/80 (US EPA 1980), and Quality Assurance Program for the Nuclear Radiation Assessment Division (US EPA 1992). The current document is Revision 2; the principal changes were that Revision 1 added the program goals, and Revision 2 changed personnel responsibilities and titles to match changing circumstances. 
The EEG QAPP describes the goals for EEG's environmental surveillance program (Section 2), the program's organization (Section 3.0), the responsibilities of the various personnel within the program (Section 3.1), training and certification requirements and methods (Section 3.2), quality objectives for both sampling and analysis (Section 4.1), the internal and external quality control programs (Section 4.2 and 4.3), document control requirements (Section 4.5), requirements for sample custody (Section 6.0), equipment calibration (Section 8.0), and data reduction, validation, and reporting (Section 9). The EEG QAPP requires that quality-affecting processes be proceduralized; the EEG Field Procedures Manual (FPM) and the EEG Laboratory Procedures Manual (LPM) contain these procedures.

An internal auditor reporting directly to the EEG director performs audits at least twice each year; these audits are performed using checklists based on the requirements listed in the QAPP, FPM, and LPM, and findings are tracked until resolved. An independent external audit is also performed each year.

\subsection{Traceability and Acceptance Criteria}

A central, guiding principle for EEG's quality assurance activities, as they relate to laboratory measurements, involves the idea of measurement traceability. The term "traceability" has been defined variously, but the International Standards Organization (ISO) defines it as

\footnotetext{
"the property of the result of a measurement or the value of a standard whereby it can be related to stated references, usually national or international standards, through an unbroken chain of comparisons all having stated uncertainties" [italics added] (ISO 1993).
}

EEG adopts the position that all laboratory measurements should exhibit the property of traceability, wherever possible. In practice we believe the requisite "unbroken chain of comparisons" is best maintained by participation in external intercomparison or measurements assurance programs providing blind samples matching, as closely as possible, the combinations of matrices and radionuclides encountered in our environmental surveillance program. In this 
way, the validity of our environmental surveillance data is supported by nationally or internationally recognized standards to the extent that the results of our analyses of intercomparison samples are deemed acceptable.

The assignment of acceptability to a result is not a straightforward process. Acceptability may be assigned with respect to program goals. Specific program goals drive the development of specific data quality objectives (DQO) and these can be used to assess acceptability with respect to goals. However, unless all interested parties (i.e., stakeholders) can agree to accept a common set of DQOs, valid comparisons between sets of data from different sources may be difficult to make and the public's confidence in results may be eroded.

This is why the idea of traceability, and the corollary issue of acceptability is important. If all laboratories participating in WIPP environmental radioactivity surveys maintain traceability to common standards, or to standards from different sources that themselves have a point of commonality, and all can agree to adopt common criteria for acceptability, data comparisons are validated, and EEG, as a technical oversight group, can best fulfill its environmental surveillance responsibility to the public.

These concerns have been addressed in two American National Standards Institute (ANSI) standards.

ANSI N42.22-1995, Traceability of Radioactive Sources to the National Institute of Standards and Technology (NIST) and Associated Instrument Quality Control (ANSI 1995) provides a simple calculation for commercial manufacturers of radioactive sources to determine whether their sources may be labeled as "traceable to NIST" within set limits. The criterion for acceptance is given by the formula:

$$
\left|v_{N}-v_{m}\right| \leq 3 \sqrt{\sigma_{N}^{2}+\sigma_{m}^{2}}
$$


where

$\mathrm{V}_{\mathrm{N}}=$ the NIST (or otherwise certified) value,

$\mathrm{V}_{\mathrm{m}}=$ the mean of the replicate measured values,

$\sigma_{\mathrm{N}}=$ the total propagated uncertainty (TPU), at 1- $\sigma$, of the certified value, and

$\sigma_{m}=$ the TPU, at $1-\sigma$, of the mean of the replicate measured values.

That is, whenever the measured bias is less than 3 times the quadratic sum of the associated uncertainties, the measurement is deemed to be traceable to NIST (or other certifying body) within the limits specified by $\sigma_{m}$. Of course, in the application of this criterion, a laboratory could set the TPU of its measured mean artificially high and still claim traceability to the certifying body. However, the magnitude of the acceptable TPU should be set by programmatic needs and should be governed by the program's DQOs. Thus, meeting the traceability acceptance criterion would not necessarily mean acceptability of the data with respect to the program's DQOs. In this way, a laboratory maintains control of its own data assessment while providing a point of comparison with other laboratories.

ANSI N42.23-1997, Measurement and Associated Instrument Quality Assurance for Radioassay Laboratories, establishes a framework within which radioassay laboratories may demonstrate, through a system of reference and monitoring laboratories, measurement traceability to NIST. The demonstration process is called "traceability testing". The testing involves analysis by service laboratories (i.e., those providing a service - radiochemical analysis, for example - to a customer) of blind samples provided by a reference or monitoring laboratory, and reporting the results back to the reference or monitoring laboratory, which then evaluates and, often, publishes the results. This level of testing is currently provided by a number of commercial and government laboratories, such as DOE's Environmental Measurements Laboratory (EML). In a sense, then, participants in the EML Quality Assurance Program could correctly claim to be traceable to EML for their measurements. But, the ISO definition of traceability seems to be more restrictive since it requires an "unbroken chain" back to "international or national standards". EML is not the repository for the national standards in radiometrology; that responsibility lies with NIST. 
At present the N42.23 framework is not fully implemented, since the link in the chain between NIST and the reference/monitoring labs is missing. Efforts are underway to forge the final link and establish the requisite traceability relationships involving laboratories with the capability to function as reference or monitoring laboratories. These efforts will take some time to bear fruit.

In the meantime, NIST, with the support of a number of DOE- and EPA-supported and university laboratories, including EEG, has established and is running an interim program called the NIST Radiochemistry Intercomparison Program (NRIP). ${ }^{1}$ Under NRIP, NIST directly provides participants with traceability testing samples appropriate to their missions and traceability certificates, called Reports of Traceability, based on their reported results. Under this interim program, NIST is functioning as an N42.23 reference lab. A real and valid concern is that, as the program adds new participants, NIST will reach a "saturation point" and be unable to accommodate additional requests for traceability testing samples. This concern provides impetus to bring additional reference labs into the $\mathrm{N} 42.23$ framework as soon as possible.

Since shortly after the radiochemistry lab became operational in 1993, EEG has participated in the EPA's Performance Evaluation Studies Program, the EML Quality Assurance Program, and, lately, the NRIP. These programs have provided external assessments of the EEG lab's capabilities in the analyses contained within this report. The next section contains the data resulting from participation in those programs.

\subsection{Data}

The following tables contain the external QC data accumulated in support of the sample analysis results in this report. Tables 11 and 12 contain the results from analysis of water and air filters, respectively. In the following tables the results are evaluated (pass/fail or acceptable/not acceptable) with respect to both the program's DQOs and the ANSI N42.22 criterion for traceability.

${ }^{1}$ A list of current participants is available by contacting the Ionizing Radiation Division, Radioactivity Group, NIST. 
The program's DQOs are detailed in the QAPP. Briefly, they are:

$\begin{array}{lcc} & \text { Accuracy } & \text { Precision }(95 \%) \\ \text { Activities } \leq 10 \text { times MDA } & \pm 30 \% & 30 \% \\ \text { Activities }>10 \text { times MDA } & \pm 20 \% & 20 \%\end{array}$

"MDA = minimum detectable activity (see Section 3.4)

The results in these tables must pass both accuracy and precision DQOs in order to pass. The listed uncertainties are 1- $\sigma$ uncertainties.

Table 11. Results of External QC Sample Analyses in Water

\begin{tabular}{lcccccc}
\hline Sample ID & Nuclide & Units & Certified & Measured & DQO? & Traceable? \\
\hline EPA (3/94) & ${ }^{239 / 240} \mathrm{Pu}$ & $\mathrm{pCi} / 1$ & $27.6 \pm ?$ & $26.1 \pm 0.5$ & pass & $\mathrm{NA}^{*}$ \\
EPA (3/95) & ${ }^{239 / 240} \mathrm{Pu}$ & $\mathrm{pCi} / 1$ & $11.1 \pm ?$ & $11.1 \pm 0.4$ & pass & $\mathrm{NA}^{*}$ \\
EML (7/96) & ${ }^{239 / 240} \mathrm{Pu}$ & $\mathrm{Bq} / 1$ & $0.77 \pm 0.06$ & $0.71 \pm 0.03$ & pass & yes \\
EML (1/97) & ${ }^{239 / 240} \mathrm{Pu}$ & $\mathrm{Bq} / 1$ & $0.84 \pm 0.03$ & $0.89 \pm 0.01$ & pass & yes \\
EML (7/97) & ${ }^{239 / 240} \mathrm{Pu}$ & $\mathrm{Bq} / 1$ & $0.85 \pm 0.05$ & $0.82 \pm 0.02$ & pass & yes \\
NRIP (6/97) & ${ }^{239 / 240} \mathrm{Pu}$ & $\mathrm{mBq} / \mathrm{g}$ & $1.95 \pm 0.01$ & $2.03 \pm 0.07$ & pass & yes \\
EML (7/96) & ${ }^{238} \mathrm{Pu}$ & $\mathrm{Bq} / 1$ & $0.98 \pm 0.07$ & $0.94 \pm 0.04$ & pass & yes \\
EML (1/97) & ${ }^{238} \mathrm{Pu}$ & $\mathrm{Bq} / 1$ & $1.91 \pm 0.07$ & $2.00 \pm 0.02$ & pass & yes \\
EML (7/97) & ${ }^{238} \mathrm{Pu}$ & $\mathrm{Bq} / 1$ & $1.29 \pm 0.06$ & $1.27 \pm 0.03$ & pass & yes \\
NRIP (6/97) & ${ }^{238} \mathrm{Pu}$ & $\mathrm{mBq} / \mathrm{g}$ & $2.21 \pm 0.01$ & $2.19 \pm 0.08$ & pass & yes \\
EML (7/96) & ${ }^{241} \mathrm{Am}$ & $\mathrm{Bq} / 1$ & $0.77 \pm 0.01$ & $0.74 \pm 0.04$ & pass & yes \\
EML (1/97) & ${ }^{241} \mathrm{Am}$ & $\mathrm{Bq} / 1$ & $1.08 \pm 0.04$ & $1.10 \pm 0.03$ & pass & yes \\
EML (7/97) & ${ }^{241} \mathrm{Am}$ & $\mathrm{Bq} / 1$ & $0.84 \pm 0.03$ & $0.88 \pm 0.04$ & pass & yes \\
NRIP (6/97) & ${ }^{241} \mathrm{Am}$ & $\mathrm{mBq} / \mathrm{g}$ & $3.43 \pm 0.01$ & $3.32 \pm 0.16$ & pass & yes \\
\hline *evaluation against ANSI N42.22 criterion not possible because EPA did not report their measurement uncertainty
\end{tabular}


Table 12. Results of External QC Sample Analyses in Air Filters

\begin{tabular}{lccllll}
\hline Sample ID & Nuclide & Units & \multicolumn{1}{c}{ Certified } & Measured & DQO? & Traceable? \\
\hline EPA (8/93) & ${ }^{137} \mathrm{Cs}$ & $\mathrm{pCi} /$ filter & $9.0 \pm ?$ & $10.3 \pm 0.6$ & pass & NA $^{\mathrm{a}}$ \\
EPA (8/94) & ${ }^{137} \mathrm{Cs}$ & $\mathrm{pCi} /$ filter & $15.0 \pm ?$ & $17.0 \pm 1.0$ & pass & $\mathrm{NA}^{\mathrm{a}}$ \\
EPA (8/95) & ${ }^{137} \mathrm{Cs}$ & $\mathrm{pCi} /$ filter & $25.0 \pm ?$ & $25.0 \pm 1.0$ & pass & $\mathrm{NA}^{\mathrm{a}}$ \\
EML (7/96) & ${ }^{137} \mathrm{Cs}$ & $\mathrm{Bq} /$ filter & $6.64 \pm 0.70$ & $4.50 \pm 0.26$ & fail & yes \\
EML (1/97) & ${ }^{137} \mathrm{Cs}$ & $\mathrm{Bq} /$ filter & $8.52 \pm 0.37$ & $9.44 \pm 0.20$ & pass & yes \\
EML (7/97) & ${ }^{137} \mathrm{Cs}$ & $\mathrm{Bq} /$ filter & $8.70 \pm 0.80$ & $10.10 \pm 0.50$ & pass & yes \\
EML (7/96) & ${ }^{239 / 240} \mathrm{Pu}$ & $\mathrm{Bq} /$ filter & $0.093 \pm 0.003$ & $0.102 \pm 0.007$ & pass & yes \\
NRIP (8/97) & ${ }^{239 / 240} \mathrm{Pu}$ & $\mathrm{mBq} /$ filter & $50.8 \pm 0.2^{\mathrm{b}}$ & $52.0 \pm 1.9$ & pass & yes \\
EML (7/96) & ${ }^{238} \mathrm{Pu}$ & $\mathrm{Bq} /$ filter & $0.096 \pm 0.002$ & $0.108 \pm 0.007$ & pass & yes \\
EML (1/97) & ${ }^{238} \mathrm{Pu}$ & $\mathrm{Bq} /$ filter & $0.118 \pm 0.006$ & $0.119 \pm 0.003$ & pass & yes \\
NRIP (8/97) & ${ }^{238} \mathrm{Pu}$ & $\mathrm{mBq} /$ filter & $57.5 \pm 0.3^{\mathrm{b}}$ & $56.8 \pm 2.3$ & pass & yes \\
EML (7/96) & ${ }^{241} \mathrm{Am}$ & $\mathrm{Bq} /$ filter & $0.189 \pm 0.007$ & $0.186 \pm 0.012$ & pass & yes \\
EML (1/97) & ${ }^{241} \mathrm{Am}$ & $\mathrm{Bq} /$ filter & $0.222 \pm 0.019$ & $0.223 \pm 0.013$ & pass & yes \\
EML (7/97) & ${ }^{241} \mathrm{Am}$ & $\mathrm{Bq} /$ filter & $0.152 \pm 0.013$ & $0.080 \pm 0.008$ & fail & no \\
NRIP (8/97) & ${ }^{241} \mathrm{Am}$ & $\mathrm{mBq} /$ filter & $89.3 \pm 0.4^{\mathrm{b}}$ & $87.2 \pm 2.7$ & pass & yes \\
\hline
\end{tabular}

a evaluation against ANSI N42.22 criterion not possible because EPA did not report their measurement uncertainty.

b average of five certified values

The ${ }^{137} \mathrm{Cs}$ result from sample EML (7/96) provides an illustration of the risk of relying on only one set of criteria in the evaluation of QC results. Here is a situation where the traceability criterion was satisfied but the accuracy requirement of the DQOs was not, and an investigation was triggered. Data for ${ }^{137} \mathrm{Cs}$ are obtained from counting the $662-\mathrm{keV}$ gamma line on a reverseelectrode germanium system. EEG uses certified calibration standards in the determination of counting efficiency for air filters which duplicate our standard filter geometries collected in the field. The EML filter geometry is very different and, as a result, the counting efficiency had to be estimated. When the results for the 7/96 round were obtained, appropriate corrections to the counting efficiency were applied and subsequent filter results have been acceptable. 
The results from the ${ }^{241} \mathrm{Am}$ analysis in filter EML (7/97) have proven to be more puzzling, especially considering that an almost identical analysis one month later in sample NRIP (8/97) yielded acceptable results. The ${ }^{243} \mathrm{Am}$ recovery monitor and ${ }^{241} \mathrm{Am}$ unknown peaks for this EML sample were poorly resolved in the spectrum. EEG does not use a peak-fitting algorithm for alpha spectroscopy. Spill-down of ${ }^{241} \mathrm{Am}$ activity into the ${ }^{243} \mathrm{Am}$ recovery monitor region would cause the recovered ${ }^{241} \mathrm{Am}$ activity to appear artificially low and the calculated chemical recovery, based on ${ }^{243} \mathrm{Am}$ activity, to appear artificially high. Both effects would tend to lead to the observed result. Another possible explanation is that, since the EML filter sample is a single filter shipped in a sealed plastic bag, spiked activity could transfer from the filter to the bag in shipping. The normal procedure is to wash the inside of the bag with dilute acid when the filter is transferred for analysis. It is possible that this procedure was not followed in this instance which could help to explain the low result. In any event, we do not believe this result calls into question any sample analyses which may have been occurring at that time, since the magnitude of the total uncertainty in sample results at environmental levels is usually equal to or greater than the result itself and this level of uncertainty encompasses the apparent bias in the EML sample in question. 


\subsection{CONCLUSIONS}

Average concentrations of radionuclides measured in environmental media during 1993, 1994 and 1995 are consistent with similar measurements in New Mexico by EPA and LANL. The current methodology is appropriate for determining pre-operational baseline concentrations of ${ }^{241}$ $\mathrm{Am},{ }^{239+240} \mathrm{Pu}$ and ${ }^{238} \mathrm{Pu}$ in air and water near the WIPP facility and in surrounding communities. Sensitivity of the EEG's exhaust air monitoring program is sufficient to quantify any increase in environmental levels of these radionuclides which are about 1000 times below regulatory limits contained in 40 CFR 61 Subpart H and 40 CFR 191 Subpart A.

Measurement of ${ }^{241} \mathrm{Am},{ }^{239+240} \mathrm{Pu}$ and ${ }^{238} \mathrm{Pu}$ concentrations in water effluent from the facility can identify an increase above background 10 times below the regulatory limit contained in 40 CFR 191 Subpart A.

Additional confidence in the EEG analytical process comes from participation in various external laboratory intercomparison programs and independent program audits. Results from these programs and audits have been good. 



\section{REFERENCES}

American National Standards Institute, 1995. American National Standard - Traceability of radioactive sources to the National Institute of Standards and Technology (NIST) and associated instrument quality control. ANSI N42.22-1995.

Berry, H. A., 1989. An aerial radiological survey of the Waste Isolation Pilot Plant and surrounding area, Carlsbad, New Mexico. AMO-8809, EG\&G Energy Measurements.

Chandra, Sumit, Carlos A. Ortiz, and Andrew R. McFarland, 1993. Performance of the WIPP shrouded probe at $20 \mathrm{~m} / \mathrm{s}$. Texas A\& M University, Aerosol Technology Laboratory.

Chaturvedi, Lokesh and James K. Channell, 1985. The Rustler formation as a transport medium for contaminated groundwater. EEG-32, Environmental Evaluation Group.

Corley, J. P., D. H. Denham, R. E. Jaquish, D. E. Michels, A. R. Olsen, and D. A. Waite, 1981. A guide for environmental radiological surveillance at U. S. Department of Energy installations. DOE/EP-0023, U. S. Department of Energy.

International Organization for Standardization, 1993. International vocabulary basic and general terms in metrology. Second edition, Geneva, Switzerland.

Kenney, Jim, John Rodgers, Jenny Chapman, and Kevin Shenk, 1990. Preoperational radiation surveillance of the WIPP project by EEG, 1985-1988. EEG-43, Environmental Evaluation Group.

Kenney, Jim W. and Sally C. Ballard, 1990. Preoperational radiation surveillance of the WIPP project by EEG during 1989. EEG-47, Environmental Evaluation Group.

Kenney, Jim W., 1991. Preoperational radiation surveillance of the WIPP project by EEG during 1990. EEG-49, Environmental Evaluation Group.

Kenney, Jim W., 1992. Preoperational radiation surveillance of the WIPP project by EEG during 1991. EEG-51, Environmental Evaluation Group.

Kenney, Jim W., 1994. Preoperational radiation surveillance of the WIPP project by EEG during 1992. EEG-54, Environmental Evaluation Group.

Kenney, Jim W., Paula S. Downes, Donald H. Gray, and Sally C. Ballard, 1995. Radionuclides baseline in soil near Project Gnome and the Waste Isolation Pilot Plant. EEG-58, Environmental Evaluation Group.

Liu, B. Y. H., and D. Y. H. Pui, 1980. Aerosol sampling inlets and inhalable particles. Particle Technology Laboratory, University of Minnesota. 
Los Alamos National Laboratory, 1995. Environmental surveillance at Los Alamos during 1993. LA-12973-ENV.

Los Alamos National Laboratory, 1996a. Environmental surveillance at Los Alamos during 1994. LA-13047-ENV.

Los Alamos National Laboratory, 1996b. Environmental surveillance at Los Alamos during 1995. LA-13210-ENV.

Mercer, J. W., 1983. Geohydrology of the proposed Waste Isolation Pilot Plant site, Los Medanos area, southeastern New Mexico. Water-Resources Investigations Report 834016, U. S. Geological Survey.

National Council on Radiation Protection and Measurements, 1996. Screening models for releases of radionuclides to atmosphere, surface water, and ground. NCRP Report No. 123 , vols. I and II.

New Mexico, State of, v. U. S. Department of Energy, 1982. Supplemental stipulated agreement resolving certain state off-site concerns over WIPP. 81-0363JB, U. S. District Court, Albuquerque, NM.

Rodgers, John C. and Jim W. Kenney, 1997. Issues in establishing an aerosol radiological baseline for the Waste Isolation Pilot Plant near Carlsbad, New Mexico. Health Physics 72(2): 300-308.

Sandia National Laboratories, 1989. Systems analysis, long-term radionuclide transport, and dose assessments, Waste Isolation Pilot Plant (WIPP), southeastern New Mexico. SAND89-0462.

Silva, Matthew K. and James K. Channell, 1992. Implications of oil and gas leases at the WIPP on compliance with EPA TRU waste disposal standards. EEG-50, Environmental Evaluation Group.

Spiegler, Peter, 1984. Proposed preoperational environmental monitoring program for WIPP. EEG-26, Environmental Evaluation Group.

U.S. Congress, 1992. Waste isolation pilot plant land withdrawal act. Public Law 102-579, $102 \mathrm{~d}$ Congress.

U.S. Congress, 1993. National defense authorization act for fiscal year 1994. Public Law 103160,103 rd Congress.

U.S. Department of Commerce, National Oceanic and Atmospheric Administration, 1993. Climatological data annual summary, New Mexico 1992. C55.214/28:97/13. 
U.S. Department of Commerce, National Oceanic and Atmospheric Administration, 1994. Climatological data annual summary, New Mexico 1992. C55.214/28:98/13.

U.S. Department of Commerce, National Oceanic and Atmospheric Administration, 1995. Climatological data annual summary, New Mexico 1992. C55.214/28:99/13.

U.S. Department of Energy, Carlsbad Area Office, 1997. The national transuranic waste management plan. DOE/NTP-96-1204, Rev. 1.

U.S. Department of Energy, Waste Isolation Pilot Plant, 1991. Waste Isolation Pilot Plant site environmental report for calendar year 1990. DOE/WIPP 91-008.

U.S. Department of Energy, Waste Isolation Pilot Plant, 1997a. Waste Isolation Pilot Plant safety analysis report. DOE/WIPP-95-2065 Rev. 1, March 1997.

U.S. Department of Energy, Waste Isolation Pilot Plant, 1997b. Waste Isolation Pilot Plant safety analysis report. DOE/WIPP-DRAFT-2065 Rev. 2, October 1997.

U.S. Environmental Protection Agency, 1980. Interim guidelines and specifications for preparing quality assurance project plans. QAMS-005/80, Office of Monitoring Systems and Quality Assurance, Office of Research and Development.

U.S. Environmental Protection Agency, 1990a. Environmental radiation protection standards for management and disposal of spent nuclear fuel, high-level and transuranic radioactive wastes. 40 CFR Part 191, U. S. Code of Federal Regulations.

U.S. Environmental Protection Agency, 1990b. National emission standards for hazardous air pollutants. 40 CFR Part 61, U. S. Code of Federal Regulations.

U.S. Environmental Protection Agency, 1992. Quality assurance program plan for the nuclear radiation assessment division: offsite radiation safety program. Internal Report, Revised April 1992, Environmental Monitoring Systems Laboratory, Las Vegas, NV.

U.S. Environmental Protection Agency, 1994. Environmental radiation data report 74 April June 1993. EPA-402-R-93-093, Office of Radiation and Indoor Air.

U.S. Environmental Protection Agency, 1996a. Environmental radiation data report 76 October December 1993. EPA-402-R-96-004, Office of Radiation and Indoor Air.

U.S. Environmental Protection Agency, 1996b. Environmental radiation data report 78 April June 1994. Office of Radiation and Indoor Air.

U.S. Environmental Protection Agency, 1997a. Environmental Radiation Data Report 80 October - December 1994. EPA-402-R-97-003, Office of Radiation and Indoor Air. 
U.S. Environmental Protection Agency, 1997b. Environmental Radiation Data Report 82 April June 1995. EPA-402-R-97-005, Office of Radiation and Indoor Air.

U.S. Nuclear Regulatory Commission, 1980. Radiological effluent and environmental monitoring at uranium mills. Regulatory Guide 4.14, Revision 1. 


\section{APPENDIX A}

\section{EXCERPTS FROM THE SUPPLEMENTAL STIPULATED AGREEMENT}

The agreement for the joint environmental monitoring program between the State of New Mexico and the U. S. Department of Energy is contained in the December 28, 1982 Supplemental Stipulated Agreement. The following sections are taken from pages 1 through 9 of Appendix A of that document.

Appendix A of Supplemental Stipulated Agreement The State of New Mexico's Environmental Monitoring Program for WIPP

The State of New Mexico's environmental radiation surveillance program for WIPP operations is designed to serve as an independent means to evaluate the accuracy and precision of the results as determined by the Department of Energy's program. Such a meaningful, independent State role is crucial for public confidence and acceptance given the fact that WIPP is exempted from NRC licensing and inspection requirements. In order to maintain this independence the State will require the following: (1) that split samples will be taken by a procedure approved by the State and DOE, and, if the parties so desire, under the observation of the designated representatives of both agencies on a routine collection schedule; that, where applicable, sample preparation will follow established quality assurance/quality control procedures to insure a homogenous mixture prior to taking aliquots; (2) that the sample schedule and location will be expanded or altered in accordance with any reasonable request by the representatives of the State of New Mexico; (3) that sample analyses will be performed by laboratories not affiliated with nor under contract with the Department of Energy to perform analysis of WIPP environmental monitoring samples; and (4) that a State quality control program will be established and maintained for routine calibration of air samples and thermoluminescent dosimeters in addition to the intercomparison of specific radionuclide analyses by a referee laboratory program, such as the one certified by the National Bureau of Standards or the Environmental Protection Agency. 
A. Preoperational Phase (Begins Two Years Prior to Waste Emplacement).

1. External Gamma Exposure

Duplicate thermoluminescent dosimeters (TLD's) at all of the DOE's stations.

\section{Soil}

Random split sampling and specific isotopic analyses for up to $30 \%$ of the DOE's scheduled program.

\section{Atmospheric Particulates}

Duplicate high volume air particulate sampler(s) adjacent to the DOE's station in the area of maximum predicted downwind ground deposition. The State representative may elect to monitor the sampling, monitoring and analytic process rather than take duplicate samples.

\section{Water and Sediments}

Random split samples and specific isotopic analyses for up to $30 \%$ of the DOE's scheduled program.

\section{Product and Meat}

Locally produced fruit, vegetables, meat and poultry random split samples and the same analysis for up to $30 \%$ of the DOE's scheduled program.

\section{B. Operational Phase}

The operational radiation surveillance program will be similar to the preoperational phase. The final design of the program, however, will be based on a review of the environmental data collected during the two years prior to waste emplacement operations. Two additional high volume air sampling stations are planned for (1) an area downwind determined to be the area of largest risk to population during the operational phase and, (2) a location remote and 180 degrees from the previous location and on the opposite side of the WIPP Site. 
C. Decommissioning and Decontamination Phase

The level environmental radiological surveillance developed during the operational phase shall be continued during and for at least two years following complete decommissioning and decontamination of the surface facilities. This is to include both the State and the Department of Energy's programs. In addition, increased surface soil and vegetation samples will be collected and analyzed to ensure decontamination standards in effect at the time are met.

\section{Post-Operational Phase}

The final environmental radiological surveillance phase will primarily serve to ensure the public that resuspension of contaminated ground surface particles, if any, is not creating a potential long-term inhalation problem. The program will also include continued analyses on an annual basis of some selected soil, and surface and ground water sampling locations as determined by a review of the data and/or the most critical pathways to man. The minimum program projected at this time and to be continued for a period of not less than five (5) years following termination of the decommissioning and decontamination phase is:

(1) Intermittent operation of the state-operated high volume air sample stations.

(2) Four annual soil surface samples.

(3) Four annual water samples.

(4) Thermoluminescent dosimeters. 


\section{APPENDIX B}

Note 1: "Quarter" is Calendar Quarter

Note 2: N/A in the table indicates results not available. The large number of N/A is due to unanticipated analytical problems associated with laboratory start-up 
Table B1. ${ }^{241}$ Am Concentrations in LVAS Samples During 1993

\begin{tabular}{|c|c|c|c|c|c|c|}
\hline $\begin{array}{c}\text { SAMPLE } \\
\text { LOCATION } \\
\text { CODE }\end{array}$ & $\begin{array}{c}\text { LVAS } \\
\text { SAMPLE } \\
\text { LOCATION } \\
\end{array}$ & $\begin{array}{l}\text { QUARTER } \\
\text { SAMPLE } \\
\text { COLLECTED }\end{array}$ & $\begin{array}{c}\text { SAMPLE } \\
\text { VOLUME } \\
\left(\mathrm{m}^{3}\right)\end{array}$ & $\begin{array}{c}{ }^{241} \mathrm{Am} \\
\text { COMPOSITE } \\
\text { ACTIVITY } \\
\text { (Bq/sample) }\end{array}$ & $\begin{array}{c}\text { CALCULATED } \\
{ }_{241} \mathrm{Am} \\
\text { CONC. } \\
\left(\mathrm{Bq} / \mathrm{m}^{3}\right) \\
\end{array}$ & $\begin{array}{l}{ }^{241} \mathrm{Am} \\
+/-\mathrm{TPU} \\
\left(\mathrm{Bq} / \mathrm{m}^{3}\right) \\
\end{array}$ \\
\hline$A$ & ARTESIA & 1ST QTR 93 & 25150 & $3.5 E^{-04}$ & $1.4 \mathrm{E}^{-08}$ & $8.3 E^{-0 B}$ \\
\hline $\mathrm{C}$ & CARLSBAD & 1ST QTR 93 & 22957 & $-5.3 E^{-04}$ & $-2.3 E^{-08}$ & $6.7 E^{-08}$ \\
\hline $\mathrm{H}$ & HOBBS & 1ST QTR 93 & 18691 & $2.8 E^{-04}$ & $1.5 \mathrm{E}^{-08}$ & $1.2 E^{-07}$ \\
\hline $\mathbf{L}$ & LOVING & 1ST QTR 93 & 25301 & N/A & N/A & N/A \\
\hline 1 & WIPP 1 & 1ST QTR 93 & 24531 & $-4.0 E^{-05}$ & $-1.6 E^{-09}$ & $7.4 \mathrm{E}^{-08}$ \\
\hline 2 & WIPP 2 & 1ST QTR 93 & 26653 & $-8.9 E^{-04}$ & $-3.3 E^{-08}$ & $7.2 E^{-08}$ \\
\hline 3 & WIPP 3 & 1ST QTR 93 & 22408 & N/A & N/A & N/A \\
\hline A & ARTESIA & 2ND QTR 93 & 23615 & N/A & N/A & N/A \\
\hline C & CARLSBAD & 2ND QTR 93 & 19179 & N/A & N/A & N/A \\
\hline $\mathrm{H}$ & HOBBS & 2ND QTR 93 & 21676 & $N / A$ & N/A & $N / A$ \\
\hline$L$ & LOVING & 2ND QTR 93 & 11697 & N/A & N/A & N/A \\
\hline 1 & WIPP 1 & 2ND QTR 93 & 22726 & N/A & N/A & N/A \\
\hline 2 & WIPP 2 & 2ND QTR 93 & 21276 & N/A & N/A & N/A \\
\hline 3 & WIPP 3 & 2ND QTR 93 & 23668 & N/A & N/A & N/A \\
\hline A & ARTESIA & 3RD QTR 93 & 23752 & N/A & N/A & N/A \\
\hline C & CARLSBAD & 3RD QTR 93 & 19130 & N/A & N/A & N/A \\
\hline $\mathrm{H}$ & HOBBS & 3RD QTR 93 & 21134 & N/A & N/A & N/A \\
\hline$L$ & LOVING & 3RD QTR 93 & 0 & N/A & N/A & N/A \\
\hline 1 & WIPP 1 & 3RD QTR 93 & 22845 & $N / A$ & N/A & N/A \\
\hline 2 & WIPP 2 & 3RD QTR 93 & 22424 & $9.8 E^{-04}$ & $4.4 \mathrm{E}^{-08}$ & $7.2 E^{-08}$ \\
\hline 3 & WIPP 3 & 3RD QTR 93 & 20624 & $2.7 E^{-03}$ & $1.3 E^{-07}$ & $8.9 E^{-08}$ \\
\hline A & ARTESIA & 4TH QTR 93 & 21357 & $1.5 \mathrm{E}^{-03}$ & $6.8 \mathrm{E}^{-08}$ & $7.9 \mathrm{E}^{-08}$ \\
\hline $\mathrm{C}$ & CARLSBAD & 4TH QTR 93 & 22039 & N/A & N/A & N/A \\
\hline $\mathrm{H}$ & HOBBS & 4TH QTR 93 & 22798 & N/A & N/A & N/A \\
\hline L & LOVING & 4TH QTR 93 & 21910 & N/A & N/A & N/A \\
\hline 1 & WIPP 1 & 4TH QTR 93 & 25024 & N/A & N/A & N/A \\
\hline 2 & WIPP 2 & 4TH QTR 93 & 21703 & $8.0 E^{-03}$ & $3.9 E^{-07}$ & $1.1 E^{-07}$ \\
\hline 3 & WIPP 3 & 4TH QTR 93 & 18855 & $4.6 \mathrm{E}^{-03}$ & $2.4 \mathrm{E}^{-07}$ & $1.0 \mathrm{E}^{-07}$ \\
\hline
\end{tabular}




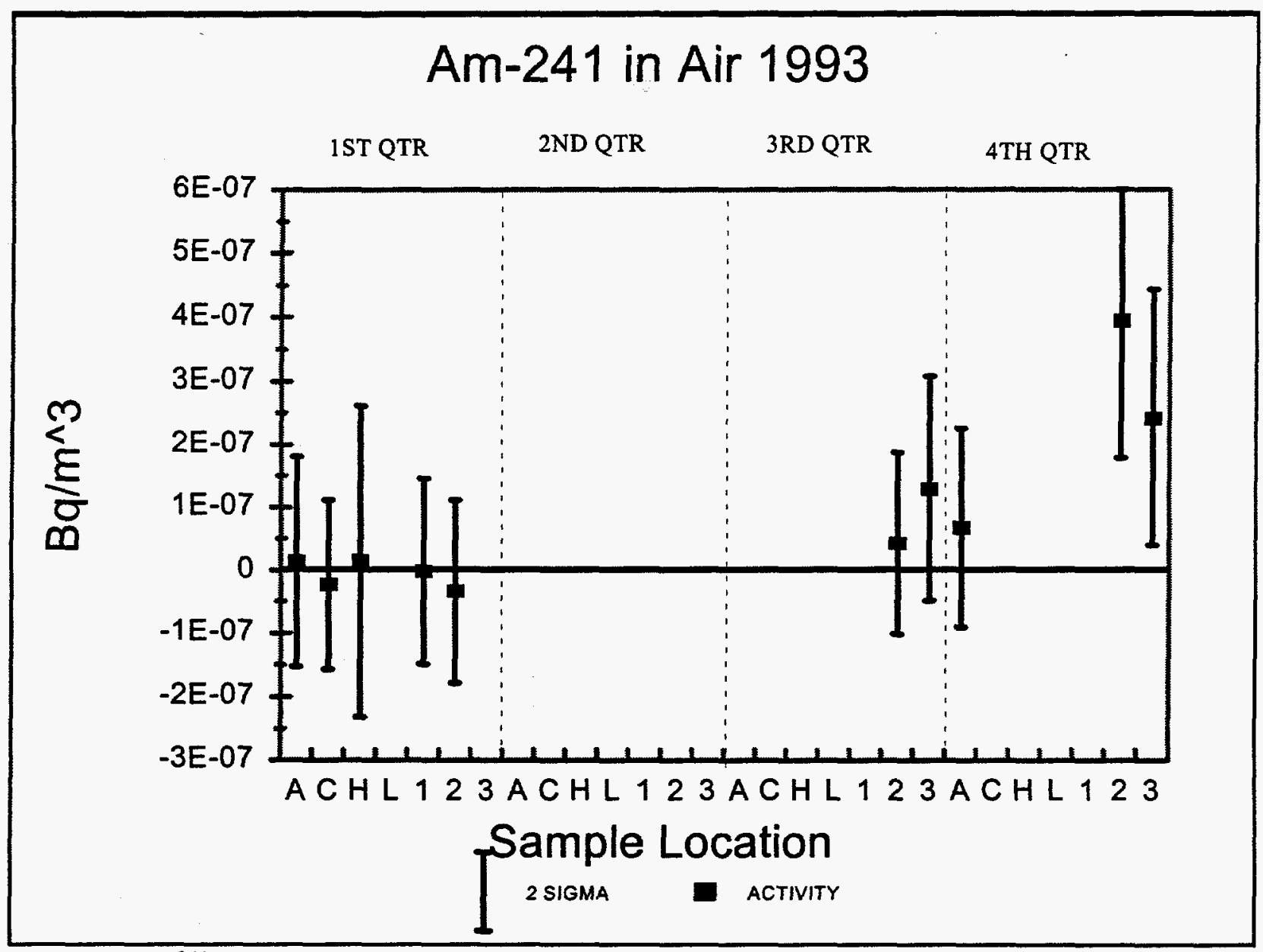

Figure B1. ${ }^{241} \mathrm{Am}$ Concentrations in Air Particulates Collected in 1993 
Table B2. ${ }^{241}$ Am Concentrations in LVAS Samples During 1994

\begin{tabular}{|c|c|c|c|c|c|c|}
\hline $\begin{array}{l}\text { SAMPLE } \\
\text { LOCATION } \\
\text { CODE } \\
\end{array}$ & $\begin{array}{c}\text { LVAS } \\
\text { SAMPLE } \\
\text { LOCATION }\end{array}$ & $\begin{array}{l}\text { QUARTER } \\
\text { SAMPLE } \\
\text { COLLECTED }\end{array}$ & $\begin{array}{c}\text { SAMPLE } \\
\text { VOLUME } \\
\left(\mathrm{m}^{3}\right)\end{array}$ & $\begin{array}{c}{ }^{241} \mathrm{Am} \\
\text { COMPOSITE } \\
\text { ACTIVITY } \\
\text { (Bq/sample) }\end{array}$ & $\begin{array}{l}\text { CALCULATED } \\
{ }^{241} \mathrm{Am} \\
\text { CONC. } \\
\left(\mathrm{Bq} / \mathrm{m}^{3}\right) \\
\end{array}$ & $\begin{array}{l}{ }^{241} \mathrm{Am} \\
+/-\mathrm{TPU} \\
\left(\mathrm{Bg} / \mathrm{m}^{3}\right)\end{array}$ \\
\hline $\bar{A}$ & ARTESIA & 1ST QTR 94 & 25851 & $2.1 \mathrm{E}^{-03}$ & $8.2 E^{-08}$ & $6.8 \mathrm{E}^{-08}$ \\
\hline $\mathrm{C}$ & CARLSBAD & 1ST QTR 94 & 25180 & $6.9 \mathrm{E}^{-03}$ & $2.7 \mathrm{E}^{-07}$ & $8.7 \mathrm{E}^{-08}$ \\
\hline $\mathrm{H}$ & HOBBS & 1ST QTR 94 & 25570 & $2.3 E^{-03}$ & $8.9 \mathrm{E}^{-08}$ & $7.3 E^{-08}$ \\
\hline$L$ & LOVING & 1ST QTR 94 & 24657 & $1.9 \mathrm{E}^{-03}$ & $7.5 \mathrm{E}^{-08}$ & $7.4 E^{-08}$ \\
\hline 1 & WIPP 1 & 1ST QTR 94 & 22609 & $4.3 E^{-04}$ & $1.9 E^{-08}$ & $7.6 \mathrm{E}^{-08}$ \\
\hline 2 & WIPP 2 & 1ST QTR 94 & 26279 & $-1.9 E^{-04}$ & $-7.4 E^{-09}$ & $6.7 E^{-08}$ \\
\hline 3 & WIPP 3 & 1ST QTR 94 & 26101 & $8.4 E^{-04}$ & $3.2 \mathrm{E}^{-08}$ & $6.1 E^{-08}$ \\
\hline A & ARTESIA & 2ND QTR 94 & 22439 & $3.3 E^{-03}$ & $1.5 E^{-07}$ & $8.4 E^{-08}$ \\
\hline C & CARLSBAD & 2ND QTR 94 & 28211 & $1.4 E^{-03}$ & $5.0 \mathrm{E}^{-08}$ & $5.7 E^{-08}$ \\
\hline $\mathrm{H}$ & HOBBS & 2ND QTR 94 & 23557 & $8.6 \mathrm{E}^{-04}$ & $3.7 \mathrm{E}^{-08}$ & $7.1 E^{-08}$ \\
\hline$L$ & LOVING & 2ND QTR 94 & 25540 & $2.4 \mathrm{E}^{-03}$ & $9.6 \mathrm{E}^{-08}$ & $6.9 \mathrm{E}^{-08}$ \\
\hline 1 & WIPP 1 & 2ND QTR 94 & 26284 & $-5.3 E^{-04}$ & $-2.0 E^{-08}$ & $6.2 \mathrm{E}^{-08}$ \\
\hline 2 & WIPP 2 & 2ND QTR 94 & 21465 & N/A & N/A & N/A \\
\hline 3 & WIPP 3 & 2ND QTR 94 & 25379 & N/A & N/A & N/A \\
\hline A & ARTESIA & 3RD QTR 94 & 15235 & $1.4 \mathrm{E}^{-03}$ & $9.0 \mathrm{E}^{-08}$ & $9.7 \mathrm{E}^{-08}$ \\
\hline C & CARLSBAD & 3RD QTR 94 & 24716 & $1.4 E^{-03}$ & $5.7 E^{-08}$ & $7.1 E^{-08}$ \\
\hline$H$ & HOBBS & 3RD QTR 94 & 23570 & $4.5 \mathrm{E}^{-04}$ & $1.9 E^{-08}$ & $6.9 \mathrm{E}^{-08}$ \\
\hline$L$ & LOVING & 3RD QTR 94 & 24089 & $5.1 \mathrm{E}^{-04}$ & $2.1 \mathrm{E}^{-08}$ & $7.0 \mathrm{E}^{-08}$ \\
\hline 1 & WIPP 1 & 3RD QTR 94 & 28377 & $1.4 \mathrm{E}^{-03}$ & $5.1 \mathrm{E}^{-08}$ & $5.6 \mathrm{E}^{-08}$ \\
\hline 2 & WIPP 2 & 3RD QTR 94 & 29103 & N/A & N/A & N/A \\
\hline 3 & WIPP 3 & 3RD QTR 94 & 28994 & N/A & N/A & N/A \\
\hline A & ARTESIA & 4TH QTR 94 & 28491 & $-4.0 E^{-04}$ & $-1.4 E^{-08}$ & $5.2 \mathrm{E}^{-08}$ \\
\hline C & CARLSBAD & 4TH QTR 94 & 30233 & $8.4 \mathrm{E}^{-04}$ & $2.8 \mathrm{E}^{-08}$ & $5.0 \mathrm{E}^{-08}$ \\
\hline $\mathrm{H}$ & HOBBS & 4TH QTR 94 & 27319 & $-1.8 E^{-04}$ & $-6.5 E^{-09}$ & $5.4 E^{-08}$ \\
\hline $\mathbf{L}$ & LOVING & 4TH QTR 94 & 27545 & $4.1 \mathrm{E}^{-05}$ & $1.5 \mathrm{E}^{-09}$ & $5.5 E^{-08}$ \\
\hline 1 & WIPP 1 & 4TH QTR 94 & 29160 & $-2.1 E^{-05}$ & $-7.1 E^{-10}$ & $5.0 \mathrm{E}^{-08}$ \\
\hline 2 & WIPP 2 & 4TH QTR 94 & 30185 & $-2.9 E^{-04}$ & $-9.7 E^{-09}$ & $4.8 E^{-08}$ \\
\hline 3 & WIPP 3 & 4TH QTR 94 & 29007 & $4.3 \mathrm{E}^{-05}$ & $1.5 E^{-09}$ & $5.1 \mathrm{E}^{-08}$ \\
\hline
\end{tabular}




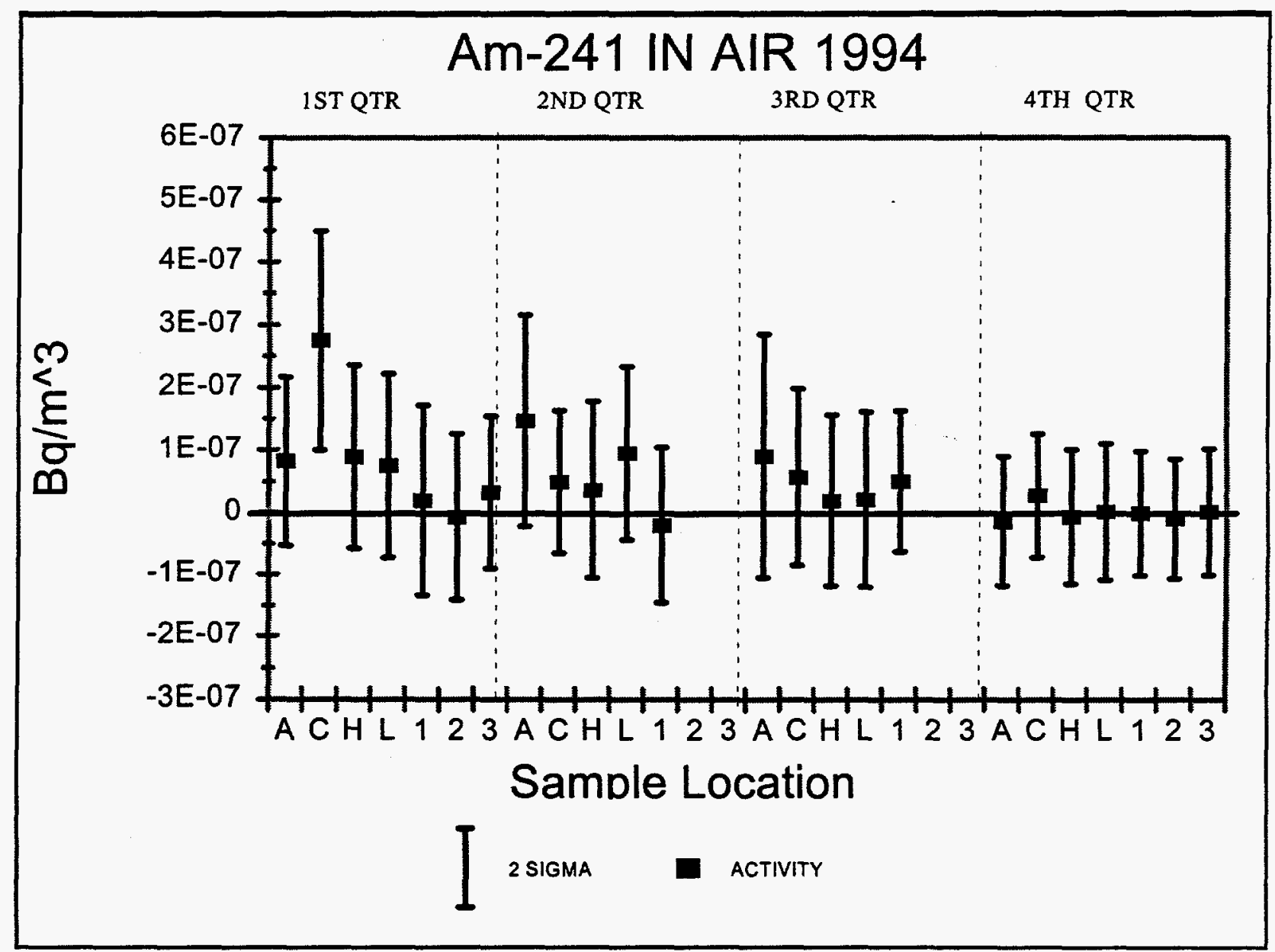

Figure B2. ${ }^{241} \mathrm{Am}$ Concentrations in Air Particulates Collected in 1994 
Table B3. ${ }^{241}$ Am Concentrations in LVAS Samples During 1995

\begin{tabular}{|c|c|c|c|c|c|c|}
\hline $\begin{array}{c}\text { SAMPLE } \\
\text { LOCATION } \\
\text { CODE } \\
\end{array}$ & $\begin{array}{c}\text { LVAS } \\
\text { SAMPLE } \\
\text { LOCATION }\end{array}$ & $\begin{array}{l}\text { QUARTER } \\
\text { SAMPLE } \\
\text { COLLECTED }\end{array}$ & $\begin{array}{c}\text { SAMPLE } \\
\text { VOLUME } \\
\left(\mathrm{m}^{3}\right)\end{array}$ & $\begin{array}{c}{ }^{241} \mathrm{Am} \\
\text { COMPOSITE } \\
\text { ACTIVITY } \\
\text { (Bq/sample) }\end{array}$ & $\begin{array}{c}\text { CALCULATED } \\
{ }_{241} \mathrm{Am} \\
\text { CONC. } \\
\left(\mathrm{Bg} / \mathrm{m}^{3}\right) \\
\end{array}$ & $\begin{array}{l}{ }^{241} \mathrm{Am} \\
+/-\mathrm{TPU} \\
\left(\mathrm{Bg} / \mathrm{m}^{3}\right)\end{array}$ \\
\hline A & ARTESIA & 1ST QTR 95 & 28959 & $-2.5 \mathrm{E}^{-04}$ & $-8.5 E^{-09}$ & $5.0 \mathrm{E}^{-08}$ \\
\hline C & CARLSBAD & 1ST QTR 95 & 28873 & $2.0 E^{-04}$ & $7.0 E^{-09}$ & $5.1 E^{-08}$ \\
\hline $\mathrm{H}$ & HOBBS & 1ST QTR 95 & 28726 & $-2.4 E^{-04}$ & $-8.3 E^{-09}$ & $5.3 E^{-08}$ \\
\hline $\mathrm{L}$ & LOVING & 1ST QTR 95 & 28157 & $1.5 \mathrm{E}^{-04}$ & $5.2 \mathrm{E}^{-09}$ & $5.2 E^{-08}$ \\
\hline 1 & WIPP 1 & 1ST QTR 95 & 27559 & $4.8 \mathrm{E}^{-04}$ & $1.7 \mathrm{E}^{-08}$ & $5.3 E^{-08}$ \\
\hline 2 & WIPP 2 & 1ST QTR 95 & 32904 & $-1.3 E^{-04}$ & $-3.8 E^{-09}$ & $4.6 \mathrm{E}^{-08}$ \\
\hline 3 & WIPP 3 & 1ST QTR 95 & 31883 & $4.4 \mathrm{E}^{-05}$ & $1.4 \mathrm{E}^{-09}$ & $4.6 \mathrm{E}^{-08}$ \\
\hline A & ARTESIA & 2ND QTR 95 & 23129 & $6.0 \mathrm{E}^{-04}$ & $2.6 \mathrm{E}^{-08}$ & $6.4 E^{-08}$ \\
\hline $\mathrm{C}$ & CARLSBAD & 2ND QTR 95 & 24121 & $2.2 \mathrm{E}^{-04}$ & $9.1 \mathrm{E}^{-09}$ & $6.3 \mathrm{E}^{-08}$ \\
\hline $\mathrm{H}$ & HOBBS & 2ND QTR 95 & 25524 & $1.6 \mathrm{E}^{-03}$ & $6.2 \mathrm{E}^{-08}$ & $5.9 E^{-08}$ \\
\hline L & LOVING & 2ND QTR 95 & 23396 & $-7.6 \mathrm{E}^{-04}$ & $-3.2 E^{-0 B}$ & $6.3 E^{-08}$ \\
\hline 1 & WIPP 1 & 2ND QTR 95 & 27045 & $1.0 E^{-04}$ & $3.8 \mathrm{E}^{-09}$ & $5.4 E^{-08}$ \\
\hline 2 & WIPP 2 & 2ND QTR 95 & 30487 & N/A & N/A & N/A \\
\hline 3 & WIPP 3 & 2ND QTR 95 & 28822 & $2.6 \mathrm{E}^{-04}$ & $9.0 \mathrm{E}^{-09}$ & $5.1 \mathrm{E}^{-08}$ \\
\hline A & ARTESIA & 3RD QTR 95 & 19867 & $2.9 \mathrm{E}^{-04}$ & $1.5 E^{-08}$ & $8.0 E^{-08}$ \\
\hline C & CARLSBAD & 3RD QTR 95 & 24639 & $-5.1 E^{-05}$ & $-2.1 E^{-09}$ & $6.1 E^{-08}$ \\
\hline$H$ & HOBBS & 3RD QTR 95 & 26249 & $-3.3 E^{-04}$ & $-1.3 E^{-0 B}$ & $5.7 \mathrm{E}^{-08}$ \\
\hline $\mathbf{L}$ & LOVING & 3RD QTR 95 & 24622 & $-4.5 \mathrm{E}^{-04}$ & $-1.8 E^{-08}$ & $5.9 \mathrm{E}^{-08}$ \\
\hline 1 & WIPP 1 & 3RD QTR 95 & 23954 & $8.4 E^{-03}$ & $3.5 \mathrm{E}^{-07}$ & $7.6 E^{-08}$ \\
\hline 2 & WIPP 2 & 3RD QTR 95 & 26134 & $1.2 E^{-03}$ & $4.6 \mathrm{E}^{-08}$ & $6.8 E^{-08}$ \\
\hline 3 & WIPP 3 & 3RD QTR 95 & 28212 & $-1.1 E^{-03}$ & $-3.9 E^{-08}$ & $5.7 \mathrm{E}^{-08}$ \\
\hline A & ARTESIA & 4TH QTR 95 & 25506 & $-8.3 E^{-05}$ & $-3.2 E^{-09}$ & $5.8 \mathrm{E}^{-08}$ \\
\hline $\mathrm{C}$ & CARLSBAD & 4TH QTR 95 & 27559 & $-2.4 E^{-04}$ & $-8.8 E^{-09}$ & $5.4 E^{-08}$ \\
\hline $\mathrm{H}$ & HOBBS & 4TH QTR 95 & 26018 & $7.4 E^{-04}$ & $2.8 \mathrm{E}^{-08}$ & $5.9 \mathrm{E}^{-08}$ \\
\hline$L$ & LOVING & 4TH QTR 95 & 28083 & $5.9 \mathrm{E}^{-04}$ & $2.1 E^{-08}$ & $5.4 E^{-08}$ \\
\hline 1 & WIPP 1 & 4TH QTR 95 & 28014 & $4.7 \mathrm{E}^{-04}$ & $1.7 E^{-08}$ & $5.3 E^{-08}$ \\
\hline 2 & WIPP 2 & 4TH QTR 95 & 30284 & $4.1 E^{-04}$ & $1.3 E^{-08}$ & $5.0 \mathrm{E}^{-08}$ \\
\hline 3 & WIPP 3 & 4TH QTR 95 & 25170 & $-1.4 E^{-03}$ & $-5.7 E^{-08}$ & $6.5 E^{-08}$ \\
\hline
\end{tabular}




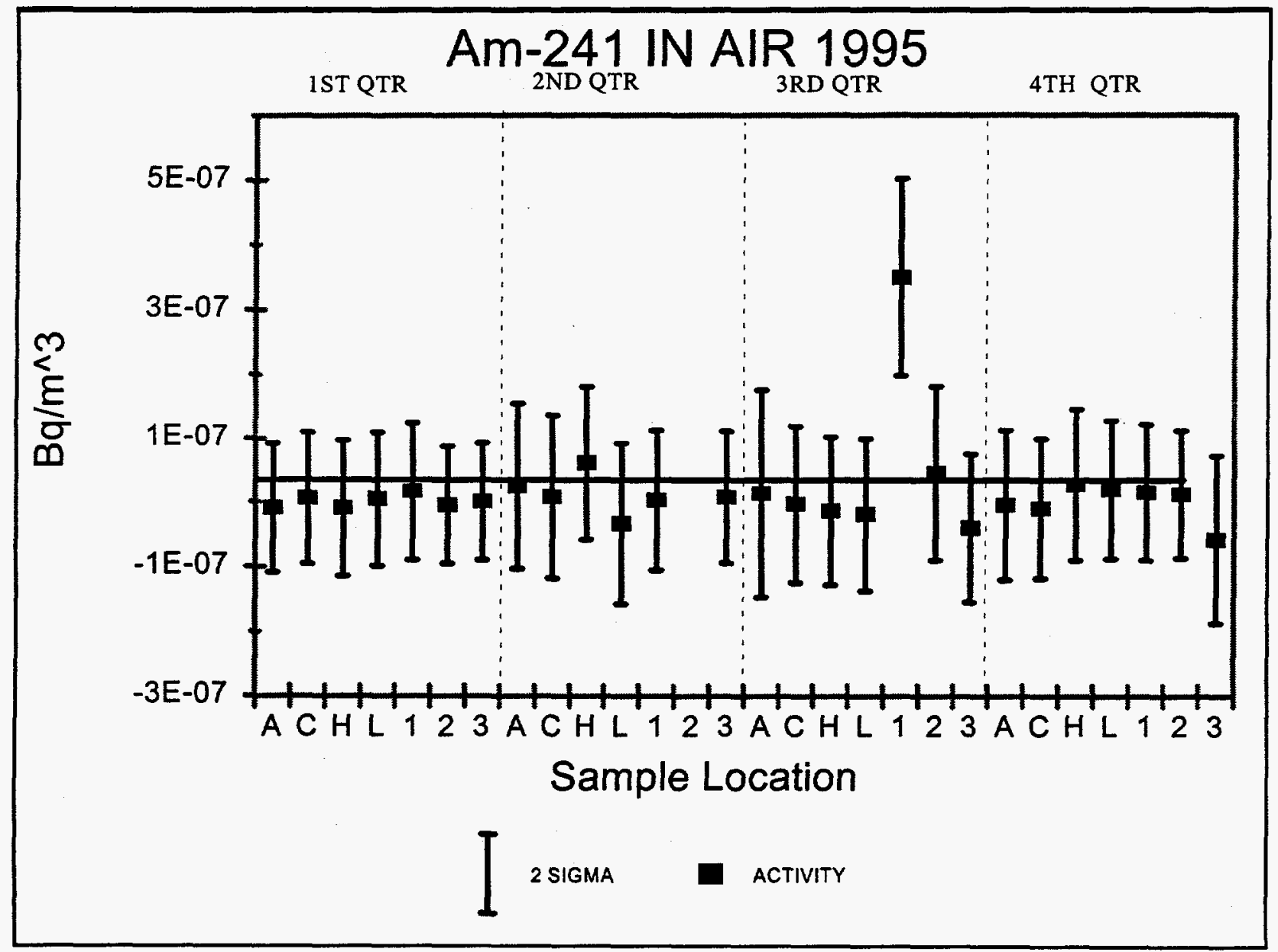

Figure B3. ${ }^{241}$ Am Concentrations in Air Particulates Collected in 1995 
Table B4. ${ }^{239+240} \mathrm{Pu}$ Concentrations in LVAS Samples During 1993

\begin{tabular}{|c|c|c|c|c|c|c|}
\hline $\begin{array}{l}\text { SAMPLE } \\
\text { LOCATION } \\
\text { CODE }\end{array}$ & $\begin{array}{c}\text { LVAS } \\
\text { SAMPLE } \\
\text { LOCATION }\end{array}$ & $\begin{array}{l}\text { QUARTER } \\
\text { SAMPLE } \\
\text { COLLECTED }\end{array}$ & $\begin{array}{c}\text { SAMPLE } \\
\text { VOLUME } \\
\left(\mathrm{m}^{3}\right)\end{array}$ & $\begin{array}{c}\text { SAMPLE } \\
\text { COMPOSITE } \\
\text { ACTIVITY } \\
\text { (Bg/sample) }\end{array}$ & $\begin{array}{c}\text { CALCULATED } \\
{ }_{239+240} \mathrm{Pu} \\
\text { CONC. } \\
\left(\mathrm{Bg} / \mathrm{m}^{3}\right)\end{array}$ & $\begin{array}{l}{ }^{239+240} \mathrm{Pu} \\
+1-\mathrm{TPU} \\
\left(\mathrm{Bg} / \mathrm{m}^{3}\right)\end{array}$ \\
\hline$A$ & ARTESIA & 1ST QTR 93 & 25150 & $1.4 \mathrm{E}^{-03}$ & $5.7 \mathrm{E}^{-08}$ & $6.4 \mathrm{E}^{-08}$ \\
\hline $\mathrm{C}$ & CARLSBAD & 1ST QTR 93 & 22957 & $4.8 \mathrm{E}^{-03}$ & $2.1 \mathrm{E}^{-07}$ & $7.2 \mathrm{E}^{-08}$ \\
\hline$H$ & HOBBS & 1ST QTR 93 & 18691 & $1.1 \mathrm{E}^{-03}$ & $5.8 \mathrm{E}^{-08}$ & $4.9 E^{-08}$ \\
\hline$L$ & LOVING & 1ST QTR 93 & 25301 & $N / A$ & N/A & N/A \\
\hline 1 & WIPP 1 & 1ST QTR 93 & 24531 & $8.9 E^{-04}$ & $3.6 \mathrm{E}^{-08}$ & $3.2 E^{-08}$ \\
\hline 2 & WIPP 2 & 1ST QTR 93 & 26653 & $4.9 \mathrm{E}^{-03}$ & $1.8 \mathrm{E}^{-07}$ & $4.4 E^{-08}$ \\
\hline 3 & WIPP 3 & 1ST QTR 93 & 22408 & $8.8 E^{-04}$ & $3.9 \mathrm{E}^{-08}$ & $3.9 E^{-08}$ \\
\hline A & ARTESIA & 2ND QTR 93 & 23615 & N/A & N/A & N/A \\
\hline C & CARLSBAD & 2ND QTR 93 & 19179 & N/A & N/A & N/A \\
\hline $\mathrm{H}$ & HOBBS & 2ND QTR 93 & 21676 & N/A & N/A & N/A \\
\hline L & LOVING & 2ND QTR 93 & 11697 & $7.3 E^{-05}$ & $6.3 \mathrm{E}^{-09}$ & $7.2 E^{-08}$ \\
\hline 1 & WIPP 1 & 2ND QTR 93 & 22726 & $-1.2 E^{-03}$ & $-5.2 E^{-08}$ & $4.0 \mathrm{E}^{-08}$ \\
\hline 2 & WIPP 2 & 2ND QTR 93 & 21276 & $1.4 \mathrm{E}^{-03}$ & $6.6 E^{-08}$ & $4.9 \mathrm{E}^{-08}$ \\
\hline 3 & WIPP 3 & 2ND QTR 93 & 23668 & $7.0 \mathrm{E}^{-04}$ & $3.0 \mathrm{E}^{-08}$ & $3.9 E^{-08}$ \\
\hline$A$ & ARTESIA & 3RD QTR 93 & 23752 & N/A & N/A & N/A \\
\hline C & CARLSBAD & 3RD QTR 93 & 19130 & N/A & N/A & N/A \\
\hline $\mathrm{H}$ & HOBBS & 3RD QTR 93 & 21134 & N/A & N/A & N/A \\
\hline $\mathbf{L}$ & LOVING & 3RD QTR 93 & 0 & N/A & N/A & N/A \\
\hline 1 & WIPP 1 & 3RD QTR 93 & 22845 & N/A & N/A & N/A \\
\hline 2 & WIPP 2 & 3RD QTR 93 & 22424 & $4.9 \mathrm{E}^{-04}$ & $2.2 \mathrm{E}^{-08}$ & $3.7 E^{-08}$ \\
\hline 3 & WIPP 3 & 3RD QTR 93 & 20624 & $1.1 \mathrm{E}^{-03}$ & $5.1 \mathrm{E}^{-08}$ & $5.0 \mathrm{E}^{-08}$ \\
\hline A & ARTESIA & 4TH QTR 93 & 21357 & $1.1 \mathrm{E}^{-03}$ & $5.2 E^{-08}$ & $4.7 E^{-08}$ \\
\hline $\mathrm{C}$ & CARLSBAD & 4TH QTR 93 & 22039 & $3.6 \mathrm{E}^{-04}$ & $1.6 \mathrm{E}^{-08}$ & $4.4 \mathrm{E}^{-08}$ \\
\hline $\mathrm{H}$ & HOBBS & 4TH QTR 93 & 22798 & $6.0 \mathrm{E}^{-04}$ & $2.6 \mathrm{E}^{-08}$ & $3.5 E^{-08}$ \\
\hline L & LOVING & 4TH QTR 93 & 21910 & $4.9 E^{-05}$ & $2.2 \mathrm{E}^{-09}$ & $3.7 E^{-08}$ \\
\hline 1 & WIPP 1 & 4TH QTR 93 & 25024 & $8.4 \mathrm{E}^{-05}$ & $3.4 \mathrm{E}^{-09}$ & $2.9 E^{-08}$ \\
\hline 2 & WIPP 2 & 4TH QTR 93 & 21703 & $-2.5 E^{-04}$ & $-1.1 E^{-08}$ & $3.9 E^{-08}$ \\
\hline 3 & WIPP 3 & 4TH QTR 93 & 18855 & $7.0 E^{-04}$ & $3.7 \mathrm{E}^{-08}$ & $4.4 E^{-08}$ \\
\hline
\end{tabular}




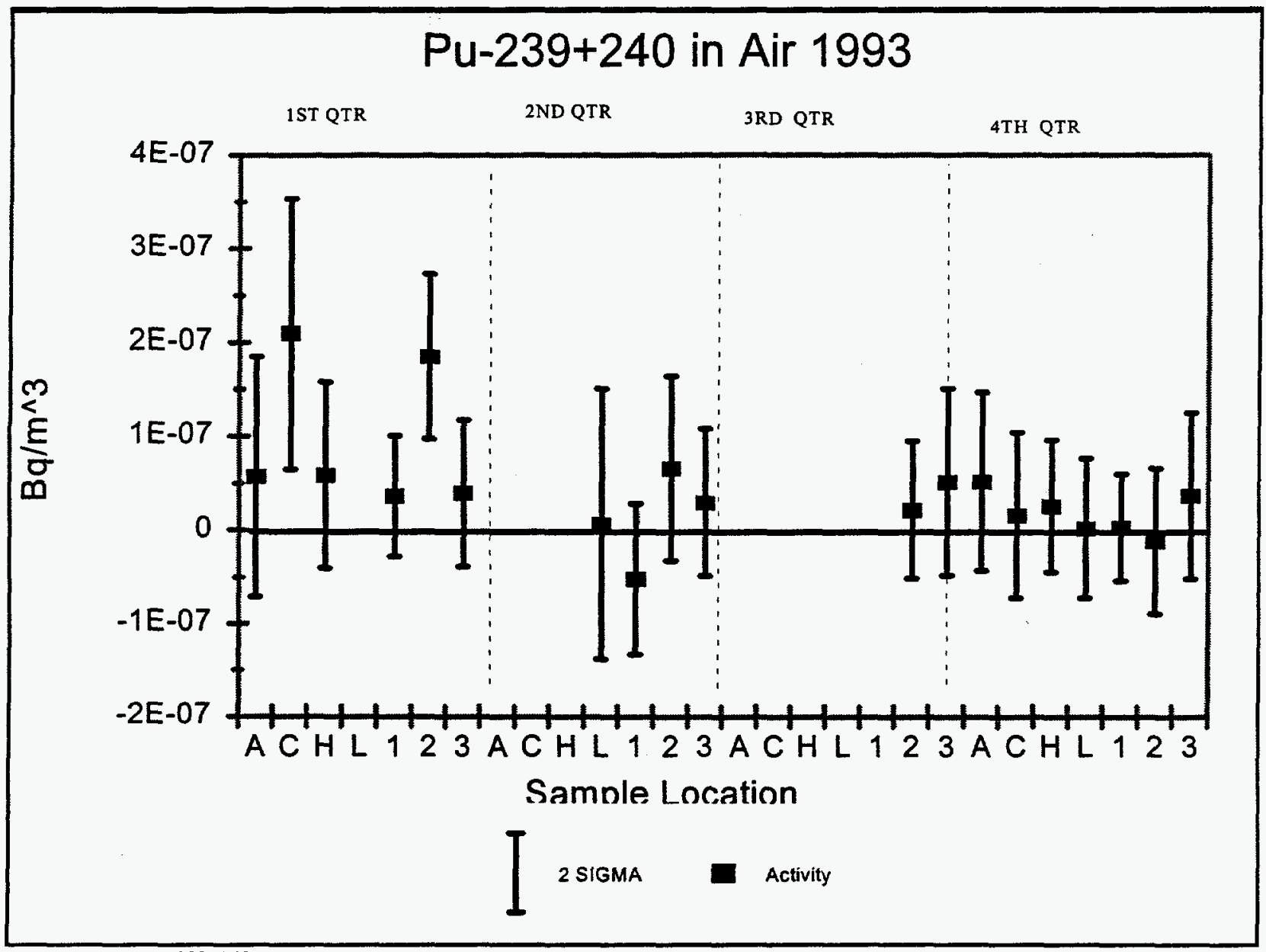

Figure B4. ${ }^{239+240} \mathrm{Pu}$ Concentrations in Air Particulates Collected in 1993 
Table B5. ${ }^{239+240} \mathrm{Pu}$ Concentrations in LVAS Samples During 1994

\begin{tabular}{|c|c|c|c|c|c|c|}
\hline $\begin{array}{c}\text { SAMPLE } \\
\text { LOCATION } \\
\text { CODE } \\
\end{array}$ & $\begin{array}{l}\text { LVAS } \\
\text { SAMPLE } \\
\text { LOCATION }\end{array}$ & $\begin{array}{l}\text { QUARTER } \\
\text { SAMPLE } \\
\text { COLLECTED }\end{array}$ & $\begin{array}{c}\text { SAMPLE } \\
\text { VOLUME } \\
\left(\mathrm{m}^{3}\right)\end{array}$ & $\begin{array}{c}\text { SAMPLE } \\
\text { COMPOSITE } \\
\text { ACTIVITY } \\
\text { (Bq/sample) }\end{array}$ & $\begin{array}{c}\text { CALCULATED } \\
{ }_{239+240} \mathrm{Pu} \\
\text { CONC. } \\
\left(\mathrm{Bg} / \mathrm{m}^{3}\right) \\
\end{array}$ & $\begin{array}{l}{ }^{239+340} \mathrm{Pu} \\
+/-\mathrm{TPU} \\
\left(\mathrm{Bq} / \mathrm{m}^{3}\right) \\
\end{array}$ \\
\hline$A$ & ARTESIA & 1ST QTR 94 & 25851 & $-2.5 \mathrm{E}^{-04}$ & $-9.6 E^{-09}$ & $2.9 \mathrm{E}^{-08}$ \\
\hline C & CARLSBAD & 1ST QTR 94 & 25180 & $4.0 \mathrm{E}^{-04}$ & $1.6 \mathrm{E}^{-08}$ & $3.1 E^{-08}$ \\
\hline $\mathrm{H}$ & HOBBS & 1ST QTR 94 & 25570 & $2.6 \mathrm{E}^{-03}$ & $1.0 \mathrm{E}^{-07}$ & $5.4 \mathrm{E}^{-08}$ \\
\hline$L$ & LOVING & 1ST QTR 94 & 24657 & $2.1 \mathrm{E}^{-03}$ & $8.5 \mathrm{E}^{-08}$ & $4.2 E^{-08}$ \\
\hline 1 & WIPP 1 & 1ST QTR 94 & 22609 & $1.6 \mathrm{E}^{-03}$ & $7.1 \mathrm{E}^{-08}$ & $4.8 E^{-08}$ \\
\hline 2 & WIPP 2 & 1ST QTR 94 & 26279 & $-2.5 E^{-04}$ & $-9.4 E^{-09}$ & $2.8 \mathrm{E}^{-08}$ \\
\hline 3 & WIPP 3 & 1ST QTR 94 & 26101 & $1.1 E^{-03}$ & $4.1 \mathrm{E}^{-08}$ & $3.3 E^{-08}$ \\
\hline$A$ & ARTESIA & 2ND QTR 94 & 22439 & $2.8 \mathrm{E}^{-03}$ & $1.2 \mathrm{E}^{-07}$ & $4.9 \mathrm{E}^{-08}$ \\
\hline C & CARLSBAD & 2ND QTR 94 & 28211 & $4.8 E^{-03}$ & $1.7 \mathrm{E}^{-07}$ & $5.3 \mathrm{E}^{-08}$ \\
\hline$H$ & HOBBS & 2ND QTR 94 & 23557 & $-2.5 E^{-04}$ & $-1.1 E^{-08}$ & $3.2 \mathrm{E}^{-08}$ \\
\hline$L$ & LOVING & 2ND QTR 94 & 25540 & $5.9 \mathrm{E}^{-04}$ & $2.3 \mathrm{E}^{-08}$ & $3.5 \mathrm{E}^{-08}$ \\
\hline 1 & WIPP 1 & 2ND QTR 94 & 26284 & $5.6 \mathrm{E}^{-04}$ & $2.1 \mathrm{E}^{-08}$ & $3.0 \mathrm{E}^{-08}$ \\
\hline 2 & WIPP 2 & 2ND QTR 94 & 21465 & N/A & N/A & N/A \\
\hline 3 & WIPP 3 & 2ND QTR 94 & 25379 & N/A & N/A & N/A \\
\hline$A$ & ARTESIA & 3RD QTR 94 & 15235 & $9.3 E^{-04}$ & $6.1 \mathrm{E}^{-08}$ & $4.6 \mathrm{E}^{-08}$ \\
\hline C & CARLSBAD & 3RD QTR 94 & 24716 & $7.6 \mathrm{E}^{-04}$ & $3.1 \mathrm{E}^{-08}$ & $2.7 E^{-08}$ \\
\hline$H$ & HOBBS & 3RD QTR 94 & 23570 & $6.9 E^{-04}$ & $2.9 E^{-08}$ & $3.0 E^{-08}$ \\
\hline $\mathbf{L}$ & LOVING & 3RD QTR 94 & 24089 & $7.3 E^{-04}$ & $3.0 \mathrm{E}^{-08}$ & $2.9 E^{-08}$ \\
\hline 1 & WIPP 1 & 3RD QTR 94 & 28377 & $4.1 E^{-04}$ & $1.4 \mathrm{E}^{-08}$ & $2.3 E^{-08}$ \\
\hline 2 & WIPP 2 & 3RD QTR 94 & 29103 & $-3.1 E^{-04}$ & $-1.0 E^{-08}$ & $2.3 E^{-08}$ \\
\hline 3 & WIPP 3 & 3RD QTR 94 & 28994 & $-3.0 E^{-04}$ & $-1.0 E^{-08}$ & $2.4 \mathrm{E}^{-08}$ \\
\hline$A$ & ARTESIA & 4TH QTR 94 & 28491 & $-1.3 E^{-04}$ & $-4.6 E^{-09}$ & $2.2 \mathrm{E}^{-08}$ \\
\hline $\mathrm{C}$ & CARLSBAD & 4TH QTR 94 & 30233 & $4.9 \mathrm{E}^{-04}$ & $1.6 \mathrm{E}^{-08}$ & $2.2 \mathrm{E}^{-08}$ \\
\hline $\mathrm{H}$ & HOBBS & 4TH QTR 94 & 27319 & $1.7 \mathrm{E}^{-04}$ & $6.1 E^{-09}$ & $2.5 \mathrm{E}^{-08}$ \\
\hline $\mathbf{L}$ & LOVING & 4TH QTR 94 & 27545 & $6.5 \mathrm{E}^{-03}$ & $2.4 \mathrm{E}^{-07}$ & $3.2 \mathrm{E}^{-08}$ \\
\hline 1 & WIPP 1 & 4TH QTR 94 & 29160 & $1.6 \mathrm{E}^{-03}$ & $5.6 \mathrm{E}^{-08}$ & $2.5 E^{-08}$ \\
\hline 2 & WIPP 2 & 4TH QTR 94 & 30185 & $1.9 E^{-03}$ & $6.4 \mathrm{E}^{-08}$ & $2.4 \mathrm{E}^{-08}$ \\
\hline 3 & WIPP 3 & 4TH QTR 94 & 29007 & $2.0 \mathrm{E}^{-03}$ & $6.9 \mathrm{E}^{-08}$ & $2.6 \mathrm{E}^{-08}$ \\
\hline
\end{tabular}




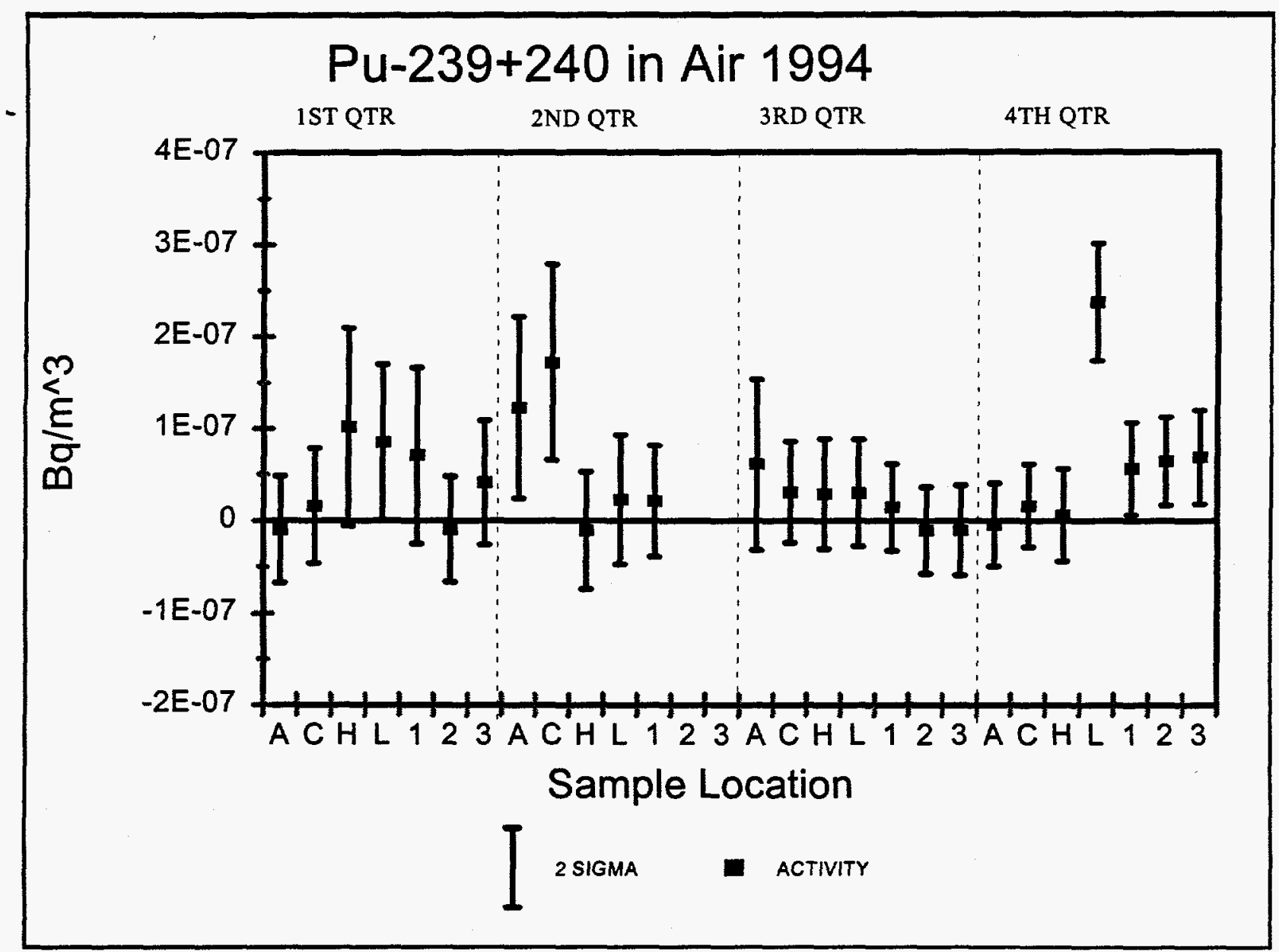

Figure B5. ${ }^{239+240} \mathrm{Pu}$ Concentrations in Air Particulates Collected in 1994 
Table B6. ${ }^{239+240} \mathrm{Pu}$ Concentrations in LVAS Samples During 1995

\begin{tabular}{|c|c|c|c|c|c|c|}
\hline $\begin{array}{l}\text { SAMPLE } \\
\text { LOCATION } \\
\text { CODE }\end{array}$ & $\begin{array}{c}\text { LVAS } \\
\text { SAMPLE } \\
\text { LOCATION }\end{array}$ & $\begin{array}{l}\text { QUARTER } \\
\text { SAMPLE } \\
\text { COLLECTED }\end{array}$ & $\begin{array}{c}\text { SAMPLE } \\
\text { VOLUME } \\
\left(\mathrm{m}^{3}\right)\end{array}$ & $\begin{array}{c}\text { SAMPLE } \\
\text { COMPOSITE } \\
\text { ACTIVITY } \\
\text { (Bq/sample) }\end{array}$ & $\begin{array}{c}\text { CALCULATED } \\
{ }_{239+240} \mathrm{Pu} \\
\text { CONC. } \\
\left(\mathrm{Bg} / \mathrm{m}^{3}\right) \\
\end{array}$ & $\begin{array}{l}{ }^{239+240} \mathrm{Pu} \\
+/-\mathrm{TPU} \\
\left(\mathrm{Bg} / \mathrm{m}^{3}\right)\end{array}$ \\
\hline$A$ & ARTESIA & 1ST QTR 95 & 28959 & $3.8 \mathrm{E}^{-04}$ & $1.3 \mathrm{E}^{-08}$ & $2.3 \mathrm{E}^{-08}$ \\
\hline C & CARLSBAD & 1ST QTR 95 & 28873 & $-4.9 E^{-05}$ & $-1.7 E^{-09}$ & $2.3 E^{-08}$ \\
\hline$H$ & HOBBS & 1ST QTR 95 & 28726 & $1.9 E^{-04}$ & $6.4 E^{-09}$ & $2.3 \mathrm{E}^{-08}$ \\
\hline L & LOVING & 1ST QTR 95 & 28157 & $9.1 E^{-06}$ & $3.2 \mathrm{E}^{-10}$ & $2.3 E^{-08}$ \\
\hline 1 & WIPP 1 & 1ST QTR 95 & 27559 & $-3.7 E^{-05}$ & $-1.3 E^{-09}$ & $2.3 E^{-08}$ \\
\hline 2 & WIPP 2 & 1ST QTR 95 & 32904 & $-2.0 E^{-05}$ & $-6.0 E^{-10}$ & $2.0 \mathrm{E}^{-08}$ \\
\hline 3 & WIPP 3 & 1ST QTR 95 & 31883 & $-6.9 E^{-05}$ & $-2.2 E^{-09}$ & $2.0 \mathrm{E}^{-08}$ \\
\hline A & ARTESIA & 2ND QTR 95 & 23129 & $7.0 \mathrm{E}^{-04}$ & $3.0 \mathrm{E}^{-08}$ & $2.9 \mathrm{E}^{-08}$ \\
\hline $\mathrm{C}$ & CARLSBAD & 2ND QTR 95 & 24121 & $4.2 \mathrm{E}^{-04}$ & $1.7 \mathrm{E}^{-08}$ & $2.8 \mathrm{E}^{-08}$ \\
\hline$H$ & HOBBS & 2ND QTR 95 & 25524 & $3.1 E^{-04}$ & $1.2 \mathrm{E}^{-08}$ & $2.6 \mathrm{E}^{-08}$ \\
\hline$L$ & LOVING & 2ND QTR 95 & 23396 & $4.9 \mathrm{E}^{-05}$ & $2.1 \mathrm{E}^{-09}$ & $2.8 \mathrm{E}^{-08}$ \\
\hline 1 & WIPP 1 & 2ND QTR 95 & 27045 & N/A & N/A & N/A \\
\hline 2 & WIPP 2 & 2ND QTR 95 & 30487 & $1.4 \mathrm{E}^{-03}$ & $4.7 \mathrm{E}^{-08}$ & $2.4 E^{-08}$ \\
\hline 3 & WIPP 3 & 2ND QTR 95 & 28822 & $3.3 E^{-03}$ & $1.1 \mathrm{E}^{-07}$ & $2.7 E^{-08}$ \\
\hline A & ARTESIA & 3RD QTR 95 & 19867 & $3.9 \mathrm{E}^{-04}$ & $2.0 \mathrm{E}^{-08}$ & $3.5 \mathrm{E}^{-08}$ \\
\hline C & CARLSBAD & 3RD QTR 95 & 24639 & $1.2 E^{-03}$ & $4.9 \mathrm{E}^{-08}$ & $3.2 E^{.08}$ \\
\hline$H$ & HOBBS & 3RD QTR 95 & 26249 & $6.0 E^{-04}$ & $2.3 E^{-08}$ & $2.7 E^{-08}$ \\
\hline$L$ & LOVING & 3RD QTR 95 & 24622 & $3.8 E^{-04}$ & $1.5 \mathrm{E}^{-08}$ & $2.7 E^{-08}$ \\
\hline 1 & WIPP 1 & 3RD QTR 95 & 23954 & $1.1 E^{-04}$ & $4.6 E^{-09}$ & $2.7 E^{-08}$ \\
\hline 2 & WIPP 2 & 3RD QTR 95 & 26134 & $6.4 \mathrm{E}^{-05}$ & $2.5 \mathrm{E}^{-09}$ & $2.5 E^{-08}$ \\
\hline 3 & WIPP 3 & 3RD QTR 95 & 28212 & $3.2 E^{-04}$ & $1.1 E^{-08}$ & $2.3 E^{-08}$ \\
\hline A & ARTESIA & 4TH QTR 95 & 25506 & $4.2 E^{-04}$ & $1.6 E^{-08}$ & $2.6 \mathrm{E}^{-08}$ \\
\hline C & CARLSBAD & 4TH QTR 95 & 27559 & $9.1 E^{-04}$ & $3.3 E^{-08}$ & $2.6 \mathrm{E}^{-08}$ \\
\hline $\mathrm{H}$ & HOBBS & 4TH QTR 95 & 26018 & $4.9 E^{-04}$ & $1.9 \mathrm{E}^{-08}$ & $2.6 \mathrm{E}^{-08}$ \\
\hline L & LOVING & 4TH QTR 95 & 28083 & $4.8 \mathrm{E}^{-04}$ & $1.7 \mathrm{E}^{-08}$ & $2.4 E^{-08}$ \\
\hline 1 & WIPP 1 & 4TH QTR 95 & 28014 & $1.6 \mathrm{E}^{-04}$ & $5.8 \mathrm{E}^{-09}$ & $2.3 E^{-08}$ \\
\hline 2 & WIPP 2 & 4TH QTR 95 & 30284 & $3.0 E^{-04}$ & $1.0 E^{-08}$ & $2.2 E^{-08}$ \\
\hline 3 & WIPP 3 & 4TH QTR 95 & 25170 & $2.7 E^{-04}$ & $1.1 \mathrm{E}^{-08}$ & $2.6 \mathrm{E}^{-08}$ \\
\hline
\end{tabular}




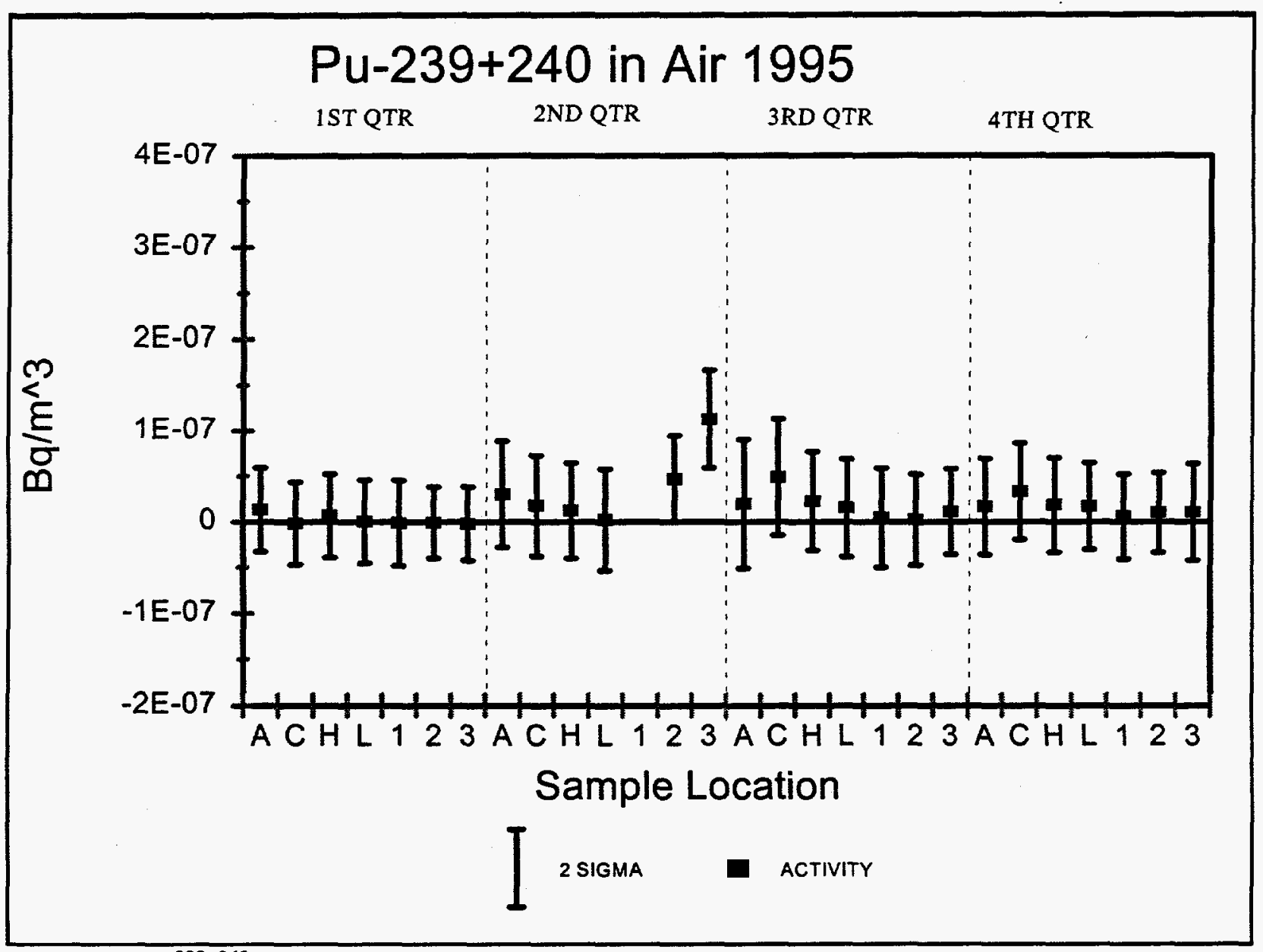

Figure B6. ${ }^{239+240} \mathrm{Pu}$ Concentrations in Air Particulates Collected in 1995 
Table B7. ${ }^{238} \mathrm{Pu}$ Concentrations in LVAS Samples During 1993

\begin{tabular}{|c|c|c|c|c|c|c|}
\hline $\begin{array}{l}\text { SAMPLE } \\
\text { LOCATION } \\
\text { CODE }\end{array}$ & $\begin{array}{c}\text { LVAS } \\
\text { SAMPLE } \\
\text { LOCATION }\end{array}$ & $\begin{array}{l}\text { QUARTER } \\
\text { SAMPLE } \\
\text { COLLECTED }\end{array}$ & $\begin{array}{c}\text { SAMPLE } \\
\text { VOLUME } \\
\left(\mathrm{m}^{3}\right)\end{array}$ & $\begin{array}{c}\text { REPORTED } \\
\text { COMPOSITE } \\
\text { ACTIVITY } \\
\text { (Bq/sample) }\end{array}$ & $\begin{array}{c}\text { CALCULATED } \\
\text { CONC. } \\
{ }_{238} \mathrm{Pu} \\
\left(\mathrm{Bq} / \mathrm{m}^{3}\right)\end{array}$ & $\begin{array}{l}{ }^{238} \mathrm{Pu} \\
+/-\mathrm{TPU} \\
\left(\mathrm{Bg} / \mathrm{m}^{3}\right)\end{array}$ \\
\hline$A$ & ARTESIA & 1ST QTR 93 & 25150 & $9.5 \mathrm{E}^{-04}$ & $3.8 \mathrm{E}^{-08}$ & $4.9 \mathrm{E}^{-08}$ \\
\hline C & CARLSBAD & 1ST QTR 93 & 22957 & $-2.7 E^{-04}$ & $-1.2 E^{-08}$ & $4.8 \mathrm{E}^{-08}$ \\
\hline $\mathrm{H}$ & HOBBS & 1ST QTR 93 & 18691 & $-3.9 E^{-04}$ & $-2.1 E^{-08}$ & $5.1 \mathrm{E}^{-08}$ \\
\hline $\mathbf{L}$ & LOVING & 1ST QTR 93 & 25301 & N/A & N/A & N/A \\
\hline 1 & WIPP 1 & 1ST QTR 93 & 24531 & $-1.6 E^{-04}$ & $-6.5 E^{-09}$ & $3.7 \mathrm{E}^{-08}$ \\
\hline 2 & WIPP 2 & 1ST QTR 93 & 26653 & $1.7 E^{-03}$ & $6.3 E^{-08}$ & $4.5 \mathrm{E}^{-08}$ \\
\hline 3 & WIPP 3 & 1ST QTR 93 & 22408 & $1.1 \mathrm{E}^{-03}$ & $4.8 E^{-08}$ & $5.7 E^{-08}$ \\
\hline$A$ & ARTESIA & 2ND QTR 93 & 23615 & N/A & N/A & N/A \\
\hline C & CARLSBAD & 2ND QTR 93 & 19179 & $N / A$ & N/A & $N / A$ \\
\hline $\mathrm{H}$ & HOBBS & 2ND QTR 93 & 21676 & N/A & N/A & N/A \\
\hline$L$ & LOVING & 2ND QTR 93 & 11697 & $5.5 E^{-04}$ & $4.7 E^{-08}$ & $9.4 E^{-08}$ \\
\hline 1 & WIPP 1 & 2ND QTR 93 & 22726 & $2.1 \mathrm{E}^{-04}$ & $9.2 E^{-09}$ & $5.3 \mathrm{E}^{-08}$ \\
\hline 2 & WIPP 2 & 2ND QTR 93 & 21276 & $-7.3 E^{-04}$ & $-3.4 E^{-08}$ & $4.8 E^{-08}$ \\
\hline 3 & WIPP 3 & 2ND QTR 93 & 23668 & $-1.2 E^{-03}$ & $-5.1 E^{-08}$ & $5.5 \mathrm{E}^{-08}$ \\
\hline A & ARTESIA & 3RD QTR 93 & 23752 & N/A & N/A & N/A \\
\hline C & CARLSBAD & 3RD QTR 93 & 19130 & N/A & N/A & N/A \\
\hline$H$ & HOBBS & 3RD QTR 93 & 21134 & N/A & N/A & N/A \\
\hline $\mathrm{L}$ & LOVING & 3RD QTR 93 & 0 & N/A & N/A & N/A \\
\hline 1 & WIPP 1 & 3RD QTR 93 & 22845 & $1.3 E^{-03}$ & $5.7 \mathrm{E}^{.08}$ & $6.4 E^{-08}$ \\
\hline 2 & WIPP 2 & 3RD QTR 93 & 22424 & $1.5 E^{-03}$ & $6.6 \mathrm{E}^{-08}$ & $5.3 E^{-08}$ \\
\hline 3 & WIPP 3 & 3RD QTR 93 & 20624 & $5.8 E^{-04}$ & $2.8 \mathrm{E}^{-08}$ & $4.9 E^{-08}$ \\
\hline A & ARTESIA & 4TH QTR 93 & 21357 & $2.0 E^{-03}$ & $9.3 E^{-08}$ & $7.6 E^{-08}$ \\
\hline $\mathrm{C}$ & CARLSBAD & 4TH QTR 93 & 22039 & $-1.2 E^{-04}$ & $-5.7 E^{-09}$ & $4.4 \mathrm{E}^{-08}$ \\
\hline $\mathrm{H}$ & HOBBS & 4TH QTR 93 & 22798 & $1.2 E^{-04}$ & $5.2 \mathrm{E}^{-09}$ & $4.0 E^{-08}$ \\
\hline $\mathbf{L}$ & LOVING & 4TH QTR 93 & 21910 & $7.6 \mathrm{E}^{-04}$ & $3.5 \mathrm{E}^{-08}$ & $5.4 E^{-08}$ \\
\hline 1 & WIPP 1 & 4TH QTR 93 & 25024 & $-7.3 E^{-04}$ & $-2.9 E^{-08}$ & $4.4 E^{-08}$ \\
\hline 2 & WIPP 2 & 4TH QTR 93 & 21703 & $-4.2 E^{-04}$ & $-1.9 E^{-08}$ & $4.3 E^{-08}$ \\
\hline 3 & WIPP 3 & 4TH QTR 93 & 18855 & $-4.1 E^{-04}$ & $-2.2 E^{-08}$ & $4.4 \mathrm{E}^{-08}$ \\
\hline
\end{tabular}




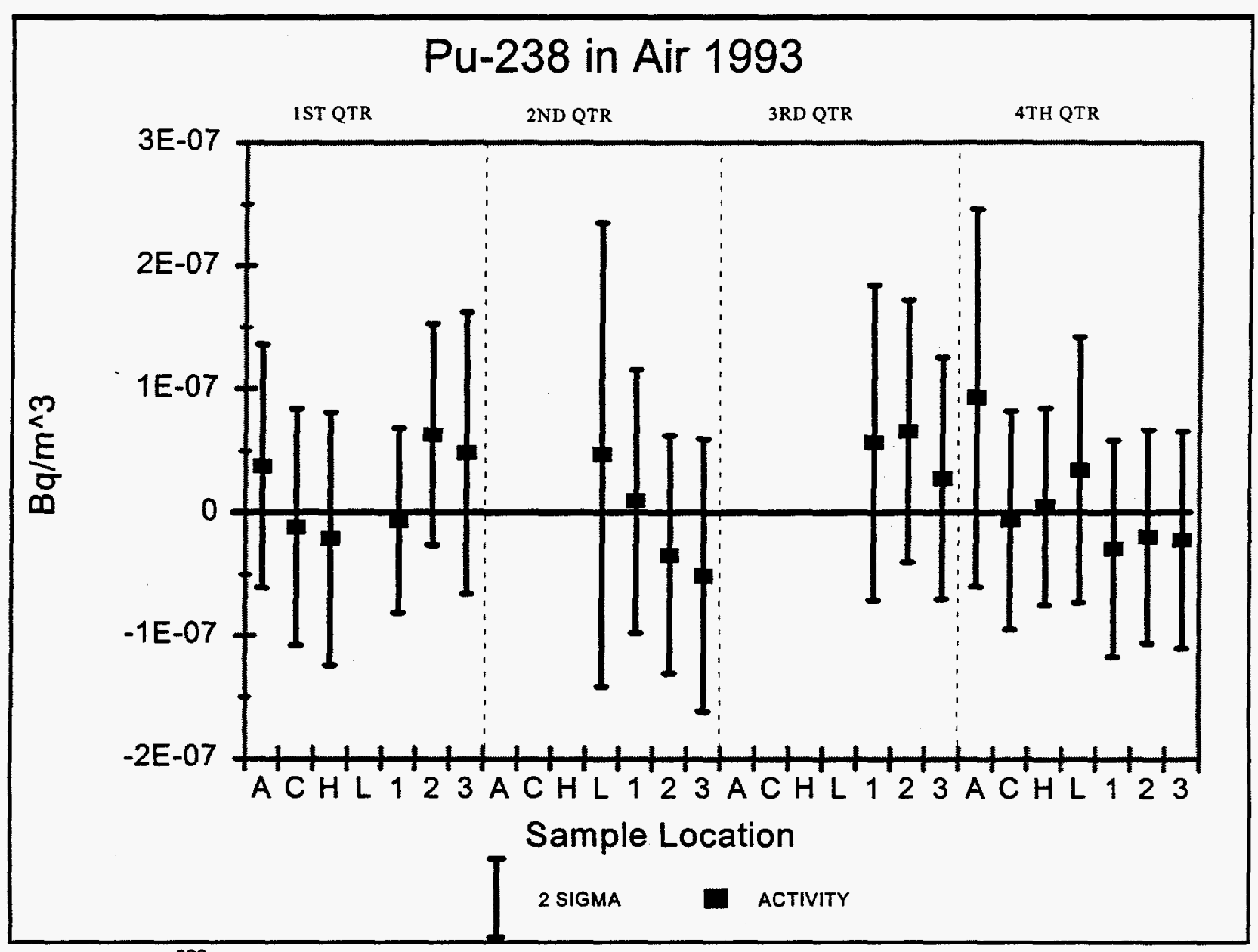

Figure B7. ${ }^{238} \mathrm{Pu}$ Concentrations in Air Particulates Collected in 1993 
Table B8. ${ }^{238} \mathrm{Pu}$ Concentrations in LVAS Samples During 1994

\begin{tabular}{|c|c|c|c|c|c|c|}
\hline $\begin{array}{c}\text { SAMPLE } \\
\text { LOCATION } \\
\text { CODE }\end{array}$ & $\begin{array}{c}\text { LVAS } \\
\text { SAMPLE } \\
\text { LOCATION }\end{array}$ & $\begin{array}{l}\text { QUARTER } \\
\text { SAMPLE } \\
\text { COLLECTED }\end{array}$ & $\begin{array}{c}\text { SAMPLE } \\
\text { VOLUME } \\
\left(\mathrm{m}^{3}\right)\end{array}$ & $\begin{array}{c}\text { REPORTED } \\
\text { COMPOSITE } \\
\text { ACTIVITY } \\
\text { (Bq/sample) }\end{array}$ & $\begin{array}{c}\text { CALCULATED } \\
\text { CONC. } \\
{ }_{238} \mathrm{Pu} \\
\left(\mathrm{Bg} / \mathrm{m}^{3}\right) \\
\end{array}$ & $\begin{array}{c}{ }^{238} \mathrm{Pu} \\
+/-\mathrm{TPU} \\
\left(\mathrm{Bg} / \mathrm{m}^{3}\right)\end{array}$ \\
\hline$A$ & ARTESIA & 1ST QTR 94 & 25851 & $-1.4 E^{-03}$ & $-5.5 E^{-08}$ & $3.5 E^{-08}$ \\
\hline C & CARLSBAD & 1ST QTR 94 & 25180 & $3.5 \mathrm{E}^{-03}$ & $1.4 \mathrm{E}^{.07}$ & $5.6 \mathrm{E}^{-08}$ \\
\hline $\mathrm{H}$ & HOBBS & 1ST QTR 94 & 25570 & $4.9 \mathrm{E}^{-04}$ & $1.9 E^{-08}$ & $4.7 E^{-08}$ \\
\hline $\mathbf{L}$ & LOVING & 1ST QTR 94 & 24657 & $1.6 \mathrm{E}^{-03}$ & $6.5 \mathrm{E}^{-08}$ & $5.2 E^{-08}$ \\
\hline 1 & WIPP 1 & 1ST QTR 94 & 22609 & $1.1 \mathrm{E}^{-03}$ & $5.0 E^{-08}$ & $5.5 E^{-08}$ \\
\hline 2 & WIPP 2 & 1ST QTR 94 & 26279 & $1.9 E^{-03}$ & $7.1 E^{-0 B}$ & $7.2 E^{-08}$ \\
\hline 3 & WIPP 3 & 1ST QTR 94 & 26101 & $3.5 \mathrm{E}^{-03}$ & $1.4 \mathrm{E}^{-07}$ & $5.3 E^{-08}$ \\
\hline A & ARTESIA & 2ND QTR 94 & 22439 & $3.6 \mathrm{E}^{-03}$ & $1.6 \mathrm{E}^{-07}$ & $6.4 E^{-08}$ \\
\hline $\mathrm{C}$ & CARLSBAD & 2ND QTR 94 & 28211 & $1.2 E^{-03}$ & $4.2 \mathrm{E}^{-08}$ & $4.2 E^{-08}$ \\
\hline $\mathrm{H}$ & HOBBS & 2ND QTR 94 & 23557 & $8.9 E^{-04}$ & $3.8 \mathrm{E}^{-08}$ & $4.9 E^{-08}$ \\
\hline L & LOVING & 2ND QTR 94 & 25540 & $-1.0 E^{-03}$ & $-4.0 E^{-08}$ & $3.2 E^{-08}$ \\
\hline 1 & WIPP 1 & 2ND QTR 94 & 26284 & $-4.6 E^{-04}$ & $-1.7 E^{-08}$ & $4.2 E^{-08}$ \\
\hline 2 & WIPP 2 & 2ND QTR 94 & 21465 & N/A & N/A & N/A \\
\hline 3 & WIPP 3 & 2ND QTR 94 & 25379 & N/A & N/A & N/A \\
\hline A & ARTESIA & 3RD QTR 94 & 15235 & $1.1 \mathrm{E}^{-03}$ & $7.0 E^{-08}$ & $5.4 E^{-08}$ \\
\hline $\mathrm{C}$ & CARLSBAD & 3RD QTR 94 & 24716 & $3.3 E^{-04}$ & $1.3 E^{-08}$ & $3.6 \mathrm{E}^{-08}$ \\
\hline$H$ & HOBBS & 3RD QTR 94 & 23570 & $1.5 \mathrm{E}^{-03}$ & $6.4 \mathrm{E}^{-08}$ & $3.9 E^{-08}$ \\
\hline$L$ & LOVING & 3RD QTR 94 & 24089 & $2.5 \mathrm{E}^{-04}$ & $1.0 \mathrm{E}^{-08}$ & $3.7 \mathrm{E}^{-08}$ \\
\hline 1 & WIPP 1 & 3RD QTR 94 & 28377 & $-1.7 E^{-04}$ & $-5.8 E^{-09}$ & $2.9 \mathrm{E}^{-08}$ \\
\hline 2 & WIPP 2 & 3RD QTR 94 & 29103 & $-7.9 E^{-04}$ & $-2.7 E^{-08}$ & $2.8 \mathrm{E}^{-08}$ \\
\hline 3 & WIPP 3 & 3RD QTR 94 & 28994 & $-1.1 E^{-03}$ & $-3.7 E^{-08}$ & $2.9 E^{-08}$ \\
\hline A & ARTESIA & 4TH QTR 94 & 28491 & $2.9 \mathrm{E}^{-05}$ & $1.0 E^{-09}$ & $2.8 \mathrm{E}^{-08}$ \\
\hline $\mathrm{C}$ & CARLSBAD & 4TH QTR 94 & 30233 & $5.9 E^{-04}$ & $2.0 E^{-08}$ & $2.7 E^{-08}$ \\
\hline $\mathrm{H}$ & HOBBS & 4TH QTR 94 & 27319 & $3.0 \mathrm{E}^{-04}$ & $1.1 \mathrm{E}^{-08}$ & $3.1 E^{-08}$ \\
\hline $\mathrm{L}$ & LOVING & 4TH QTR 94 & 27545 & $1.8 \mathrm{E}^{-03}$ & $6.4 \mathrm{E}^{-08}$ & $3.2 \mathrm{E}^{-08}$ \\
\hline 1 & WIPP 1 & 4TH QTR 94 & 29160 & $-3.1 E^{-04}$ & $-1.1 E^{-08}$ & $2.7 \mathrm{E}^{-08}$ \\
\hline 2 & WIPP 2 & 4TH QTR 94 & 30185 & $-6.3 E^{-04}$ & $-2.1 E^{-08}$ & $2.6 E^{-08}$ \\
\hline 3 & WIPP 3 & 4TH QTR 94 & 29007 & $-5.0 E^{-04}$ & $-1.7 E^{-08}$ & $2.8 E^{-08}$ \\
\hline
\end{tabular}




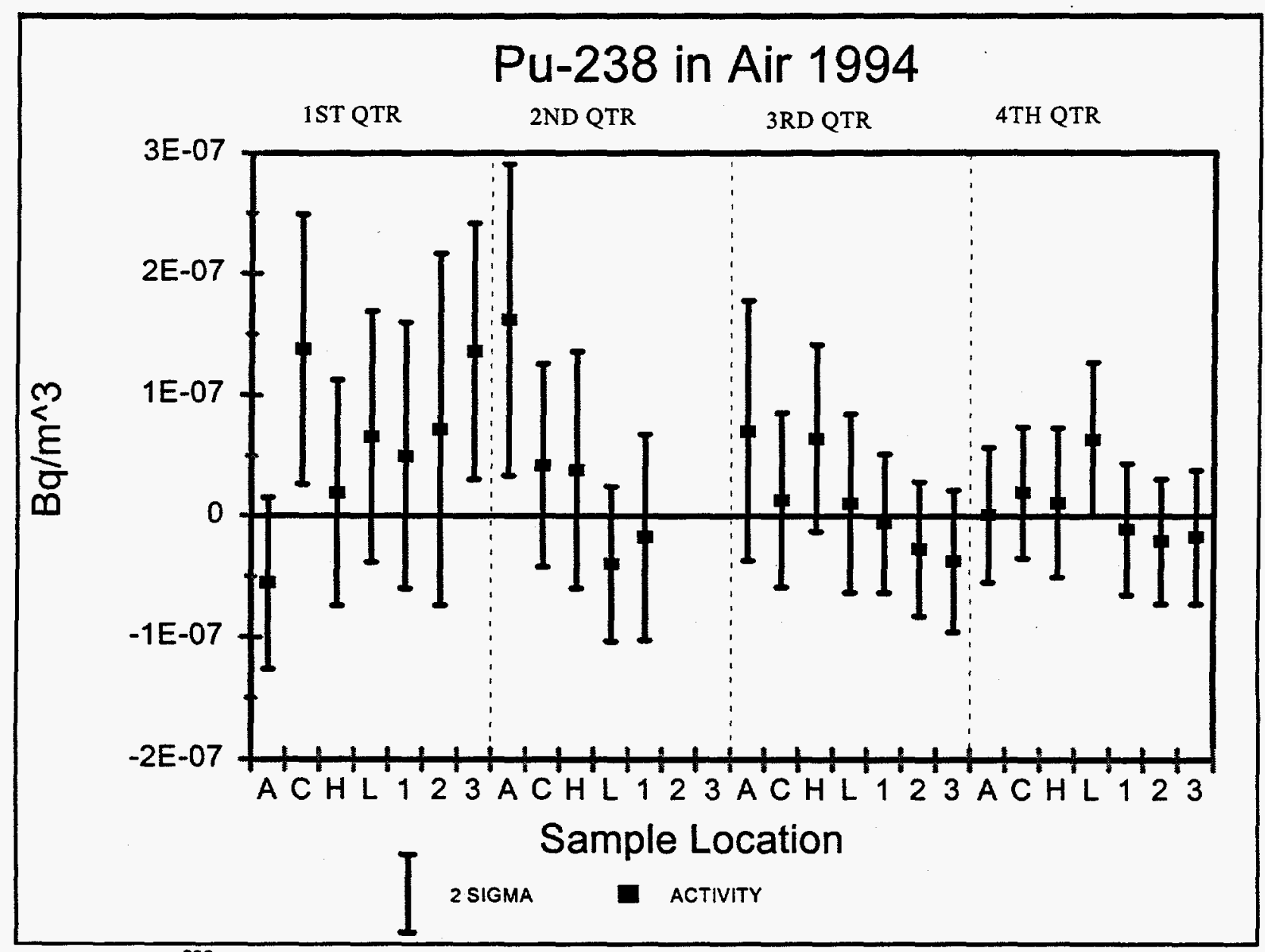

Figure B8. ${ }^{238} \mathrm{Pu}$ Concentrations in Air Particulates Collected in 1994 
Table B9. ${ }^{238} \mathrm{Pu}$ Concentrations in LVAS Samples During 1995

\begin{tabular}{|c|c|c|c|c|c|c|}
\hline $\begin{array}{l}\text { SAMPLE } \\
\text { LOCATION } \\
\text { CODE }\end{array}$ & $\begin{array}{c}\text { LVAS } \\
\text { SAMPLE } \\
\text { LOCATION }\end{array}$ & $\begin{array}{l}\text { QUARTER } \\
\text { SAMPLE } \\
\text { COLLECTED }\end{array}$ & $\begin{array}{l}\text { SAMPLE } \\
\text { VOLUME } \\
\left(\mathrm{m}^{3}\right)\end{array}$ & $\begin{array}{l}\text { REPORTED } \\
\text { COMPOSITE } \\
\text { ACTIVITY } \\
\text { (Bq/sample) }\end{array}$ & $\begin{array}{l}\text { CALCULATED } \\
\text { CONC. } \\
{ }_{238} \mathrm{Pu} \\
\left(\mathrm{Bg} / \mathrm{m}^{3}\right)\end{array}$ & $\begin{array}{l}{ }^{238} \mathrm{Pu} \\
+/-\mathrm{TPU} \\
\left(\mathrm{Bg} / \mathrm{m}^{3}\right)\end{array}$ \\
\hline$A$ & ARTESIA & 1ST QTR 95 & 28959 & $-4.8 E^{-04}$ & $-1.6 E^{-08}$ & $2.7 \mathrm{E}^{-08}$ \\
\hline C & CARLSBAD & 1ST QTR 95 & 28873 & $-6.3 E^{-04}$ & $-2.2 E^{-08}$ & $2.7 E^{-08}$ \\
\hline $\mathrm{H}$ & HOBBS & 1ST QTR 95 & 28726 & $-5.7 E^{-04}$ & $-2.0 E^{-08}$ & $2.8 \mathrm{E}^{-08}$ \\
\hline$L$ & LOVING & 1ST QTR 95 & 28157 & $-1.1 E^{-03}$ & $-3.8 E^{-08}$ & $2.8 E^{-08}$ \\
\hline 1 & WIPP 1 & 1ST QTR 95 & 27559 & $-1.5 E^{-04}$ & $-5.4 E^{-09}$ & $2.9 E^{-08}$ \\
\hline 2 & WIPP 2 & 1ST QTR 95 & 32904 & $-7.3 E^{-04}$ & $-2.2 E^{-08}$ & $2.4 \mathrm{E}^{-08}$ \\
\hline 3 & WIPP 3 & 1ST QTR 95 & 31883 & $-5.5 E^{-04}$ & $-1.7 E^{-08}$ & $2.4 \mathrm{E}^{-08}$ \\
\hline A & ARTESIA & 2ND QTR 95 & 23129 & $1.2 \mathrm{E}^{-04}$ & $5.1 \mathrm{E}^{-09}$ & $3.5 \mathrm{E}^{-08}$ \\
\hline C & CARLSBAD & 2ND QTR 95 & 24121 & $6.0 \mathrm{E}^{-04}$ & $2.5 \mathrm{E}^{-08}$ & $3.5 \mathrm{E}^{-08}$ \\
\hline $\mathrm{H}$ & HOBBS & 2ND QTR 95 & 25524 & $1.1 \mathrm{E}^{-04}$ & $4.3 E^{-09}$ & $3.2 E^{-08}$ \\
\hline$L$ & LOVING & 2ND QTR 95 & 23396 & $-3.5 E^{-05}$ & $-1.5 E^{-09}$ & $3.4 \mathrm{E}^{-08}$ \\
\hline 1 & WIPP 1 & 2ND QTR 95 & 27045 & N/A & N/A & N/A \\
\hline 2 & WIPP 2 & 2ND QTR 95 & 30487 & $-9.2 E^{-05}$ & $-3.0 E^{-09}$ & $2.7 \mathrm{E}^{-08}$ \\
\hline 3 & WIPP 3 & 2ND QTR 95 & 28822 & $-2.0 E^{-05}$ & $-6.9 E^{-10}$ & $2.8 \mathrm{E}^{-08}$ \\
\hline A & ARTESIA & 3RD QTR 95 & 19867 & $7.8 \mathrm{E}^{-04}$ & $3.9 E^{-08}$ & $4.6 \mathrm{E}^{-08}$ \\
\hline C & CARLSBAD & 3RD QTR 95 & 24639 & $2.1 E^{-04}$ & $8.4 \mathrm{E}^{-09}$ & $3.8 \mathrm{E}^{-08}$ \\
\hline $\mathrm{H}$ & HOBBS & 3RD QTR 95 & 26249 & $3.5 \mathrm{E}^{-04}$ & $1.3 \mathrm{E}^{-08}$ & $3.3 \mathrm{E}^{-08}$ \\
\hline L & LOVING & 3RD QTR 95 & 24622 & $4.1 E^{-05}$ & $1.7 \mathrm{E}^{-09}$ & $3.3 E^{-08}$ \\
\hline 1 & WIPP 1 & 3RD QTR 95 & 23954 & $6.5 \mathrm{E}^{-04}$ & $2.7 E^{-08}$ & $3.4 \mathrm{E}^{-08}$ \\
\hline 2 & WIPP 2 & 3RD QTR 95 & 26134 & $1.1 E^{-03}$ & $4.4 \mathrm{E}^{-08}$ & $3.2 \mathrm{E}^{-08}$ \\
\hline 3 & WIPP 3 & 3RD QTR 95 & 28212 & $9.1 \mathrm{E}^{-04}$ & $3.2 E^{-08}$ & $3.0 \mathrm{E}^{-08}$ \\
\hline A & ARTESIA & 4TH QTR 95 & 25506 & $-2.1 E^{-04}$ & $-8.4 E^{-09}$ & $3.2 E^{-08}$ \\
\hline $\mathrm{C}$ & CARLSBAD & 4TH QTR 95 & 27559 & $7.2 E^{-04}$ & $2.6 \mathrm{E}^{-08}$ & $3.2 \mathrm{E}^{-08}$ \\
\hline $\mathrm{H}$ & HOBBS & 4TH QTR 95 & 26018 & $4.7 \mathrm{E}^{-04}$ & $1.8 \mathrm{E}^{-08}$ & $3.2 E^{-0 B}$ \\
\hline$L$ & LOVING & 4TH QTR 95 & 28083 & $8.1 \mathrm{E}^{-04}$ & $2.9 \mathrm{E}^{-08}$ & $3.0 \mathrm{E}^{-08}$ \\
\hline 1 & WIPP 1 & 4TH QTR 95 & 28014 & $2.0 \mathrm{E}^{-04}$ & $7.0 E^{-09}$ & $2.9 E^{-0 B}$ \\
\hline 2 & WIPP 2 & 4TH QTR 95 & 30284 & $6.5 \mathrm{E}^{-04}$ & $2.1 \mathrm{E}^{-08}$ & $2.8 \mathrm{E}^{-08}$ \\
\hline 3 & WIPP 3 & 4TH QTR 95 & 25170 & $-5.4 E^{-04}$ & $-2.1 E^{-08}$ & $3.3 \mathrm{E}^{-08}$ \\
\hline
\end{tabular}




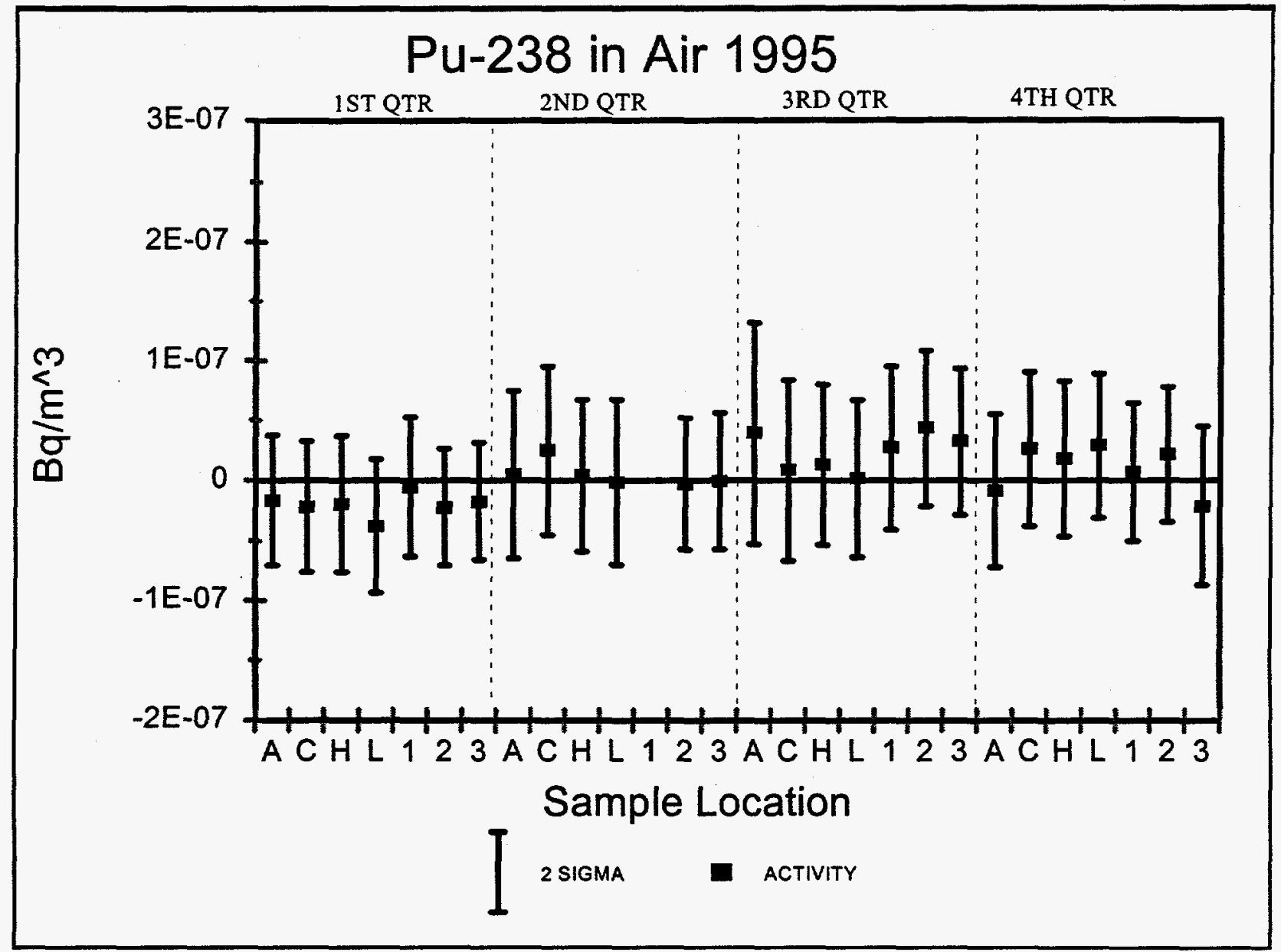

Figure B9. ${ }^{238} \mathrm{Pu}$ Concentrations in Air Particulates Collected in 1995 
Table B10. ${ }^{137}$ Cs Concentrations in LVAS Samplers During 1993

\begin{tabular}{|c|c|c|c|c|c|c|}
\hline $\begin{array}{l}\text { SAMPLE } \\
\text { LOCATION } \\
\text { CODE }\end{array}$ & $\begin{array}{c}\text { LVAS } \\
\text { SAMPLE } \\
\text { LOCATION }\end{array}$ & $\begin{array}{l}\text { QUARTER } \\
\text { SAMPLE } \\
\text { COLLECTED }\end{array}$ & $\begin{array}{c}\text { SAMPLE } \\
\text { VOLUME } \\
\left(\mathrm{m}^{3}\right)\end{array}$ & $\begin{array}{c}\text { REPORTED } \\
\text { COMPOSITE } \\
\text { ACTIVITY } \\
\text { (Bq/sample) }\end{array}$ & $\begin{array}{l}\text { CALCULATED } \\
\text { AIR CONC. } \\
{ }^{137} \mathrm{Cs} \\
\left(\mathrm{Bq} / \mathrm{m}^{3}\right)\end{array}$ & $\begin{array}{l}{ }^{137} \mathrm{Cs} \\
+/-\mathrm{TPU} \\
\left(\mathrm{Bg} / \mathrm{m}^{3}\right)\end{array}$ \\
\hline A & ARTESIA & 1ST QTR 93 & 25150 & $2.9 \mathrm{E}^{-02}$ & $1.1 E^{-06}$ & $2.4 \mathrm{E}^{-06}$ \\
\hline C & CARLSBAD & 1ST QTR 93 & 22957 & $2.9 E^{-02}$ & $1.3 \mathrm{E}^{-06}$ & $2.6 \mathrm{E}^{-06}$ \\
\hline$H$ & HOBBS & 1ST QTR 93 & 18691 & $2.1 E^{.02}$ & $1.1 \mathrm{E}^{-06}$ & $3.2 E^{-06}$ \\
\hline L & LOVING & 1ST QTR 93 & 25301 & $-3.9 E^{-02}$ & $-1.6 E^{-06}$ & $2.4 \mathrm{E}^{-06}$ \\
\hline 1 & WIPP 1 & 1ST QTR 93 & 24531 & $-1.0 E^{-02}$ & $-4.1 E^{-07}$ & $2.4 \mathrm{E}^{-06}$ \\
\hline 2 & WIPP 2 & 1ST QTR 93 & 26653 & $-1.2 E^{-03}$ & $-4.6 \mathrm{E}^{-08}$ & $2.2 \mathrm{E}^{-06}$ \\
\hline 3 & WIPP 3 & 1ST QTR 93 & 22408 & $6.9 \mathrm{E}^{-04}$ & $3.1 E^{-08}$ & $2.7 \mathrm{E}^{-06}$ \\
\hline A & ARTESIA & 2ND QTR 93 & 23615 & $-1.2 E^{-03}$ & $-5.2 E^{-08}$ & $2.5 \mathrm{E}^{.06}$ \\
\hline $\mathrm{C}$ & CARLSBAD & 2ND QTR 93 & 19179 & $-2.1 E^{-02}$ & $-1.1 E^{-06}$ & $3.2 \mathrm{E}^{-06}$ \\
\hline $\mathrm{H}$ & HOBBS & 2ND QTR 93 & 21676 & $2.7 \mathrm{E}^{-02}$ & $1.2 \mathrm{E}^{-06}$ & $2.8 E^{-05}$ \\
\hline$L$ & LOVING & 2ND QTR 93 & 11697 & $-2.0 E^{-02}$ & $-1.7 E^{-06}$ & $5.1 E^{-06}$ \\
\hline 1 & WIPP 1 & 2ND QTR 93 & 22726 & $1.1 E^{-01}$ & $4.9 \mathrm{E}^{-06}$ & $3.1 E^{-06}$ \\
\hline 2 & WIPP 2 & 2ND QTR 93 & 21276 & $-3.9 E^{-02}$ & $-1.8 E^{-06}$ & $2.9 \mathrm{E}^{-06}$ \\
\hline 3 & WIPP 3 & 2ND QTR 93 & 23668 & $-1.8 E^{-02}$ & $-7.7 \mathrm{E}^{-07}$ & $2.5 \mathrm{E}^{-06}$ \\
\hline A & ARTESIA & 3RD QTR 93 & 23752 & $-6.7 E^{-03}$ & $-2.8 E^{-07}$ & $2.6 \mathrm{E}^{-06}$ \\
\hline C & CARLSBAD & 3RD QTR 93 & 19130 & $1.3 E^{-02}$ & $6.9 \mathrm{E}^{-07}$ & $3.1 \mathrm{E}^{-06}$ \\
\hline $\mathrm{H}$ & HOBBS & 3RD QTR 93 & 21134 & $-4.9 \mathrm{E}^{-02}$ & $-2.3 E^{-06}$ & $3.0 \mathrm{E}^{-06}$ \\
\hline$L$ & LOVING & 3RD QTR 93 & 8076 & N/A & N/A & N/A \\
\hline 1 & WIPP 1 & 3RD QTR 93 & 22845 & $-3.4 E^{-02}$ & $-1.5 E^{-06}$ & $2.7 E^{-06}$ \\
\hline 2 & WIPP 2 & 3RD QTR 93 & 22424 & $2.0 E^{-02}$ & $8.9 E^{-07}$ & $2.7 E^{-06}$ \\
\hline 3 & WIPP 3 & 3RD QTR 93 & 20624 & $8.8 \mathrm{E}^{-03}$ & $4.3 E^{-07}$ & $2.9 E^{-06}$ \\
\hline A & ARTESIA & 4TH QTR 93 & 21357 & $-2.3 E^{-02}$ & $-1.1 E^{-06}$ & $2.8 \mathrm{E}^{-06}$ \\
\hline $\mathrm{C}$ & CARLSBAD & 4TH QTR 93 & 22039 & $-2.5 E^{-02}$ & $-1.1 E^{-06}$ & $2.8 \mathrm{E}^{-06}$ \\
\hline $\mathrm{H}$ & HOBBS & 4TH QTR 93 & 22798 & $-5.1 E^{-03}$ & $-2.2 E^{-07}$ & $2.6 \mathrm{E}^{-06}$ \\
\hline$L$ & LOVING & 4TH QTR 93 & 21910 & $-4.5 E^{-02}$ & $-2.1 E^{-06}$ & $2.9 \mathrm{E}^{-06}$ \\
\hline 1 & WIPP 1 & 4TH QTR 93 & 25024 & $-2.6 \mathrm{E}^{-02}$ & $-1.0 \mathrm{E}^{-06}$ & $2.4 \mathrm{E}^{-06}$ \\
\hline 2 & WIPP 2 & 4TH QTR 93 & 21703 & $2.4 \mathrm{E}^{-02}$ & $1.1 \mathrm{E}^{-06}$ & $2.8 \mathrm{E}^{-06}$ \\
\hline 3 & WIPP 3 & 4TH QTR 93 & 18855 & $3.1 \mathrm{E}^{-02}$ & $1.7 \mathrm{E}^{-06}$ & $3.2 \mathrm{E}^{-06}$ \\
\hline
\end{tabular}




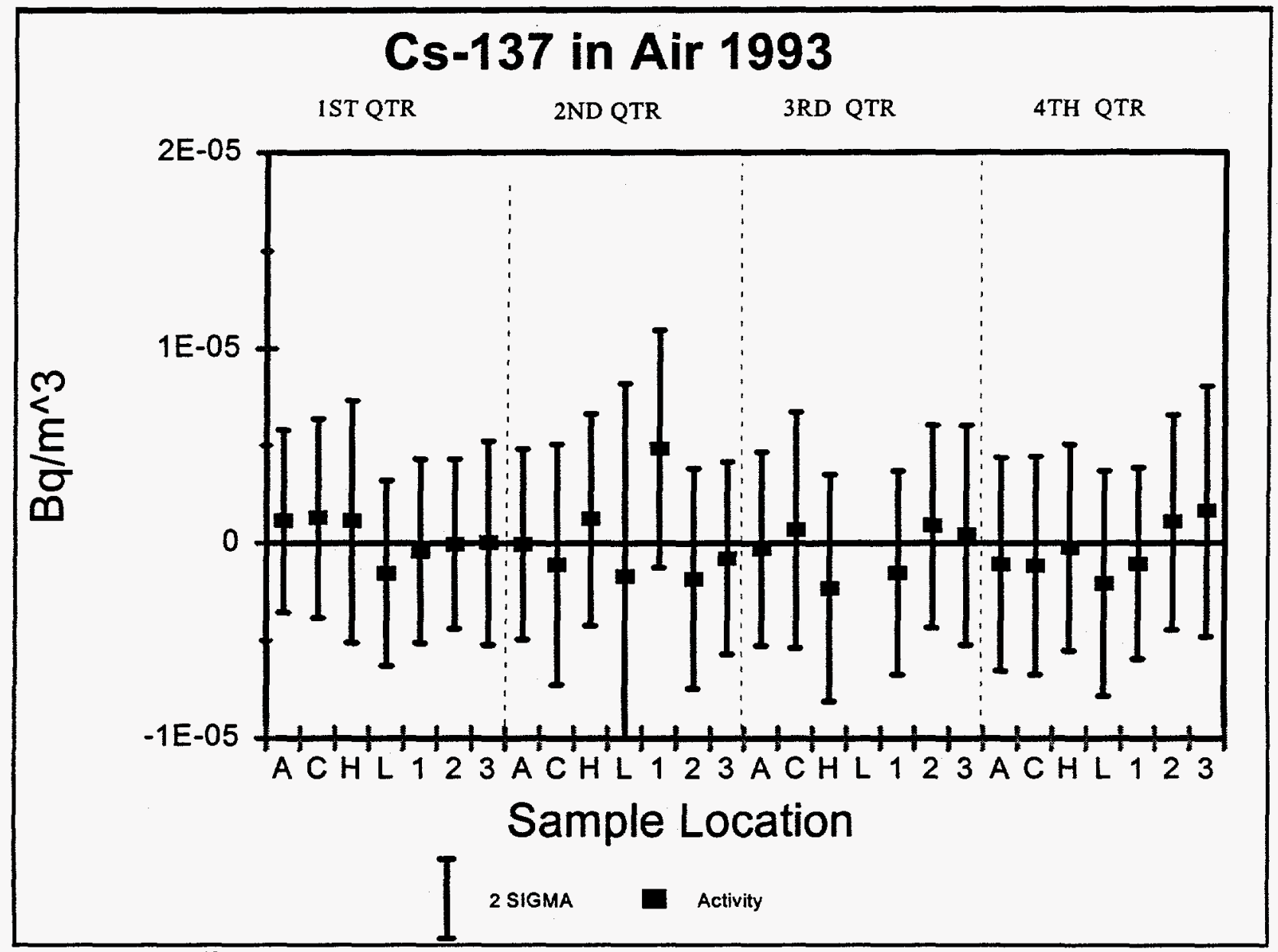

Figure B10. ${ }^{137}$ Cs Concentrations in Air Particulates Collected in 1993 
Table B11. ${ }^{137}$ Cs Concentrations in LVAS Samples During 1994

\begin{tabular}{|c|c|c|c|c|c|c|}
\hline $\begin{array}{l}\text { SAMPLE } \\
\text { LOCATION } \\
\text { CODE }\end{array}$ & $\begin{array}{c}\text { LVAS } \\
\text { SAMPLE } \\
\text { LOCATION }\end{array}$ & $\begin{array}{l}\text { QUARTER } \\
\text { SAMPLE } \\
\text { COLLECTED }\end{array}$ & $\begin{array}{c}\text { SAMPLE } \\
\text { VOLUME } \\
\left(\mathrm{m}^{3}\right)\end{array}$ & $\begin{array}{c}\text { REPORTED } \\
\text { COMPOSITE } \\
\text { ACTIVITY } \\
\text { (Bg/sample) }\end{array}$ & $\begin{array}{c}\text { CALCULATED } \\
\text { AIR CONC. } \\
{ }_{137} \mathrm{Cs} \\
\left(\mathrm{Bg} / \mathrm{m}^{3}\right) \\
\end{array}$ & $\begin{array}{l}{ }^{137} \mathrm{Cs} \\
+/-\mathrm{TPU} \\
\left(\mathrm{Bq} / \mathrm{m}^{3}\right)\end{array}$ \\
\hline$A$ & ARTESIA & 1ST QTR 94 & 25851 & $-7.6 E^{-03}$ & $-2.9 E^{-07}$ & $2.4 E^{-06}$ \\
\hline C & CARLSBAD & 1ST QTR 94 & 25180 & $-4.5 E^{-02}$ & $-1.8 E^{-06}$ & $2.5 E^{-06}$ \\
\hline $\mathrm{H}$ & HOBBS & 1ST QTR 94 & 25570 & $-1.4 E^{-03}$ & $-5.4 E^{-08}$ & $2.4 E^{-06}$ \\
\hline$L$ & LOVING & 1ST QTR 94 & 24657 & $-1.8 E^{-02}$ & $-7.2 E^{-07}$ & $2.5 E^{-06}$ \\
\hline 1 & WIPP 1 & 1ST QTR 94 & 22609 & $1.1 E^{-02}$ & $4.9 \mathrm{E}^{-07}$ & $2.7 E^{-06}$ \\
\hline 2 & WIPP 2 & 1ST QTR 94 & 26279 & $1.8 \mathrm{E}^{-02}$ & $6.8 \mathrm{E}^{-07}$ & $2.3 E^{-06}$ \\
\hline 3 & WIPP 3 & 1ST QTR 94 & 26101 & $5.6 \mathrm{E}^{-02}$ & $2.1 \mathrm{E}^{.06}$ & $2.4 E^{-06}$ \\
\hline A & ARTESIA & 2ND QTR 94 & 22439 & $3.8 E^{-03}$ & $1.7 \mathrm{E}^{-07}$ & $2.7 E^{-06}$ \\
\hline C & CARLSBAD & 2ND QTR 94 & 28211 & $-1.4 E^{-02}$ & $-5.1 E^{-07}$ & $2.1 E^{-06}$ \\
\hline $\mathrm{H}$ & HOBBS & 2ND QTR 94 & 23557 & $-2.7 E^{-02}$ & $-1.2 E^{-06}$ & $2.6 \mathrm{E}^{-05}$ \\
\hline$L$ & LOVING & 2ND QTR 94 & 25540 & $4.7 E^{-02}$ & $1.8 \mathrm{E}^{-06}$ & $2.5 E^{-06}$ \\
\hline 1 & WIPP 1 & 2ND QTR 94 & 26284 & $6.8 \mathrm{E}^{-02}$ & $2.6 \mathrm{E}^{-06}$ & $2.4 E^{-06}$ \\
\hline 2 & WIPP 2 & 2ND QTR 94 & 21465 & $7.7 E^{-03}$ & $3.6 \mathrm{E}^{-07}$ & $2.8 E^{-06}$ \\
\hline 3 & WIPP 3 & 2ND QTR 94 & 25379 & $3.4 \mathrm{E}^{-02}$ & $1.4 \mathrm{E}^{-06}$ & $2.4 E^{-06}$ \\
\hline A & ARTESIA & 3RD QTR 94 & 15235 & N/A & N/A & N/A \\
\hline C & CARLSBAD & 3RD QTR 94 & 24716 & $3.7 \mathrm{E}^{-03}$ & $1.5 E^{-07}$ & $2.4 E-06$ \\
\hline$H$ & HOBBS & 3RD QTR 94 & 23570 & $-7.6 E^{-03}$ & $-3.2 E^{-07}$ & $2.6 E^{-06}$ \\
\hline$L$ & LOVING & 3RD QTR 94 & 24089 & $3.4 E^{-02}$ & $1.4 \mathrm{E}^{-06}$ & $2.6 E^{-06}$ \\
\hline 1 & WIPP 1 & 3RD QTR 94 & 28377 & $-2.5 E^{-03}$ & $-8.7 E^{-08}$ & $2.1 E^{-06}$ \\
\hline 2 & WIPP 2 & 3RD QTR 94 & 29103 & $1.2 E^{-04}$ & $4.0 \mathrm{E}^{-09}$ & $2.1 E^{-06}$ \\
\hline 3 & WIPP 3 & 3RD QTR 94 & 28994 & $-2.1 E^{-02}$ & $-7.1 E^{-07}$ & $2.1 E^{-06}$ \\
\hline A & ARTESIA & 4TH QTR 94 & 28491 & $2.5 E^{-02}$ & $8.8 E^{-07}$ & $2.1 E^{-06}$ \\
\hline C & CARLSBAD & 4TH QTR 94 & 30233 & $-9.4 E^{-02}$ & $-3.1 E^{-06}$ & $2.3 E^{-06}$ \\
\hline $\mathrm{H}$ & HOBBS & 4TH QTR 94 & 27319 & $1.3 E^{-02}$ & $4.6 \mathrm{E}^{-07}$ & $2.2 E^{-06}$ \\
\hline L & LOVING & 4TH QTR 94 & 27545 & $5.6 \mathrm{E}^{-02}$ & $2.0 E^{-06}$ & $2.3 E^{-.06}$ \\
\hline 1 & WIPP 1 & 4TH QTR 94 & 29160 & $-3.6 E^{-02}$ & $-1.2 E^{-06}$ & $2.1 E^{-06}$ \\
\hline 2 & WIPP 2 & 4TH QTR 94 & 30185 & $-5.0 E^{-02}$ & $-1.7 E^{-06}$ & $2.1 E^{-06}$ \\
\hline 3 & WIPP 3 & 4TH QTR 94 & 29007 & $-2.2 E^{-03}$ & $-7.6 E^{-08}$ & $2.1 E^{-06}$ \\
\hline
\end{tabular}




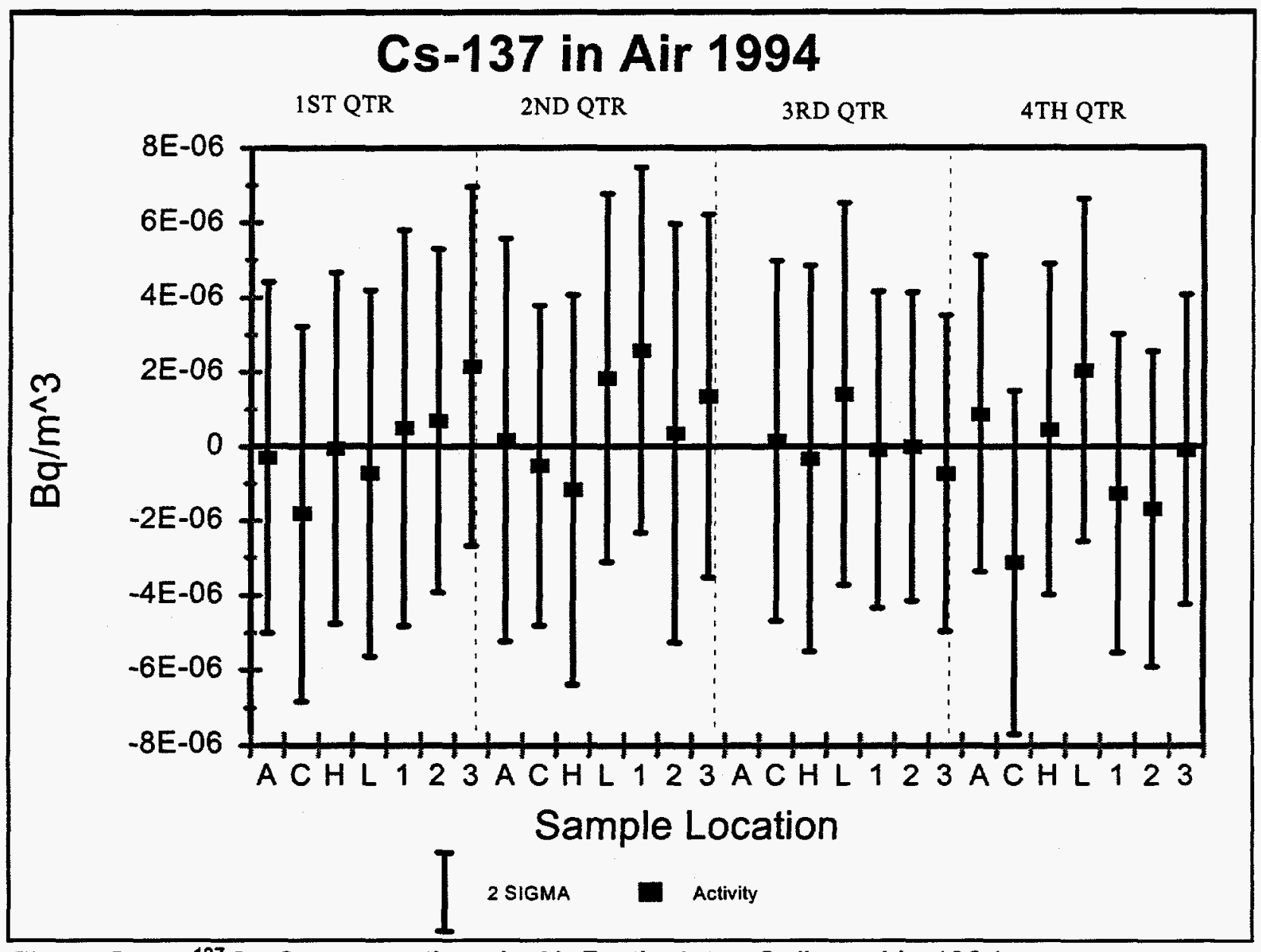

Figure B11. ${ }^{137}$ Cs Concentrations in Air Particulates Collected in 1994 
Table B12. ${ }^{137}$ Cs Concentrations in LVAS Samples During 1995

\begin{tabular}{|c|c|c|c|c|c|c|}
\hline $\begin{array}{l}\text { SAMPLE } \\
\text { LOCATION } \\
\text { CODE }\end{array}$ & $\begin{array}{c}\text { LVAS } \\
\text { SAMPLE } \\
\text { LOCATION }\end{array}$ & $\begin{array}{l}\text { QUARTER } \\
\text { SAMPLE } \\
\text { COLLECTED }\end{array}$ & $\begin{array}{c}\text { SAMPLE } \\
\text { VOLUME } \\
\left(\mathrm{m}^{3}\right)\end{array}$ & $\begin{array}{c}\text { REPORTED } \\
\text { COMPOSITE } \\
\text { ACTIVITY } \\
\text { (Bq/sample) }\end{array}$ & $\begin{array}{l}\text { CALCULATED } \\
\text { AIR CONC. } \\
{ }_{137} \mathrm{Cs} \\
\left(\mathrm{Bq} / \mathrm{m}^{3}\right)\end{array}$ & $\begin{array}{l}{ }^{137} \mathrm{Cs} \\
+/-\mathrm{TPU} \\
\left(\mathrm{Bq} / \mathrm{m}^{3}\right)\end{array}$ \\
\hline$A$ & ARTESIA & 1ST QTR 95 & 28959 & $4.9 \mathrm{E}^{-02}$ & $1.7 \mathrm{E}^{-06}$ & $2.1 \mathrm{E}^{-06}$ \\
\hline C & CARLSBAD & 1ST QTR 95 & 28873 & $3.4 \mathrm{E}^{-02}$ & $1.2 E^{-06}$ & $2.1 E^{-06}$ \\
\hline $\mathrm{H}$ & HOBBS & 1ST QTR 95 & 28726 & $8.8 E^{-03}$ & $3.1 \mathrm{E}^{-07}$ & $2.1 E^{-06}$ \\
\hline$L$ & LOVING & 1ST QTR 95 & 28157 & $2.0 \mathrm{E}^{-02}$ & $7.0 \mathrm{E}^{-07}$ & $2.1 E^{-06}$ \\
\hline 1 & WIPP 1 & 1ST QTR 95 & 27559 & $-3.4 E^{-02}$ & $-1.2 E^{-06}$ & $2.2 \mathrm{E}^{-06}$ \\
\hline 2 & WIPP 2 & 1ST QTR 95 & 32904 & $-5.5 E^{-02}$ & $-1.7 E^{-06}$ & $1.9 \mathrm{E}^{-06}$ \\
\hline 3 & WIPP 3 & 1ST QTR 95 & 31883 & $-5.6 E^{-02}$ & $-1.8 E^{-06}$ & $2.0 \mathrm{E}^{-06}$ \\
\hline A & ARTESIA & 2ND QTR 95 & 23129 & $4.7 E^{-02}$ & $2.0 \mathrm{E}^{-06}$ & $2.7 \mathrm{E}^{-06}$ \\
\hline $\mathrm{C}$ & CARLSBAD & 2ND QTR 95 & 24121 & $3.4 \mathrm{E}^{-02}$ & $1.4 \mathrm{E}^{-06}$ & $2.5 \mathrm{E}^{-06}$ \\
\hline $\mathrm{H}$ & HOBBS & 2ND QTR 95 & 25524 & $-1.1 E^{-02}$ & $-4.5 E^{-07}$ & $2.4 \mathrm{E}^{-06}$ \\
\hline$L$ & LOVING & 2ND QTR 95 & 23396 & $5.0 \mathrm{E}^{-02}$ & $2.1 \mathrm{E}^{-06}$ & $2.7 E^{-06}$ \\
\hline 1 & WIPP 1 & 2ND QTR 95 & 27045 & $9.9 \mathrm{E}^{-03}$ & $3.7 \mathrm{E}^{-07}$ & $2.2 \mathrm{E}^{-06}$ \\
\hline 2 & WIPP 2 & 2ND QTR 95 & 30487 & $-6.0 E^{-02}$ & $-2.0 E^{-06}$ & $2.1 E^{-06}$ \\
\hline 3 & WIPP 3 & 2ND QTR 95 & 28822 & $4.7 \mathrm{E}^{-02}$ & $1.6 \mathrm{E}^{-06}$ & $2.1 \mathrm{E}^{-06}$ \\
\hline A & ARTESIA & 3RD QTR 95 & 19867 & $5.8 \mathrm{E}^{.02}$ & $2.9 \mathrm{E}^{-06}$ & $3.1 \mathrm{E}^{-06}$ \\
\hline $\mathrm{C}$ & CARLSBAD & 3RD QTR 95 & 24639 & $-2.7 E^{-02}$ & $-1.1 E^{-06}$ & $2.5 \mathrm{E}^{-06}$ \\
\hline $\mathrm{H}$ & HOBBS & 3RD QTR 95 & 26249 & $5.0 E^{-02}$ & $1.9 \mathrm{E}^{-06}$ & $2.4 \mathrm{E}^{-06}$ \\
\hline L & LOVING & 3RD QTR 95 & 24622 & $1.8 \mathrm{E}^{-02}$ & $7.2 E^{-07}$ & $2.4 \mathrm{E}^{-06}$ \\
\hline 1 & WIPP 1 & 3RD QTR 95 & 23954 & $3.8 \mathrm{E}^{-03}$ & $1.6 E^{-07}$ & $2.5 \mathrm{E}^{-06}$ \\
\hline 2 & WIPP 2 & 3RD QTR 95 & 26134 & $2.0 E^{-02}$ & $7.7 \mathrm{E}^{-07}$ & $2.3 \mathrm{E}^{-06}$ \\
\hline 3 & WIPP 3 & 3RD QTR 95 & 28212 & N/A & N/A & N/A \\
\hline A & ARTESIA & 4TH QTR 95 & 25506 & $5.5 \mathrm{E}^{-02}$ & $2.2 \mathrm{E}^{-06}$ & $2.5 E^{-06}$ \\
\hline C & CARLSBAD & 4TH QTR 95 & 27559 & $7.0 E^{-02}$ & $2.5 \mathrm{E}^{-06}$ & $2.4 \mathrm{E}^{-06}$ \\
\hline $\mathrm{H}$ & HOBBS & 4TH QTR 95 & 26018 & $-2.0 E^{-02}$ & $-7.5 E^{-07}$ & $2.3 \mathrm{E}^{-06}$ \\
\hline $\mathbf{L}$ & LOVING & 4TH QTR 95 & 28083 & $8.7 E^{-03}$ & $3.1 \mathrm{E}^{-07}$ & $2.2 E^{-06}$ \\
\hline 1 & WIPP 1 & 4TH QTR 95 & 28014 & $3.6 \mathrm{E}^{-02}$ & $1.3 E^{-06}$ & $2.2 \mathrm{E}^{-.06}$ \\
\hline 2 & WIPP 2 & 4TH QTR 95 & 30284 & $1.2 \mathrm{E}^{-02}$ & $3.9 E^{-07}$ & $2.0 \mathrm{E}^{-06}$ \\
\hline 3 & WIPP 3 & 4TH QTR 95 & 25170 & $-1.4 E^{-02}$ & $-5.6 \mathrm{E}^{-07}$ & $2.4 \mathrm{E}^{-06}$ \\
\hline
\end{tabular}




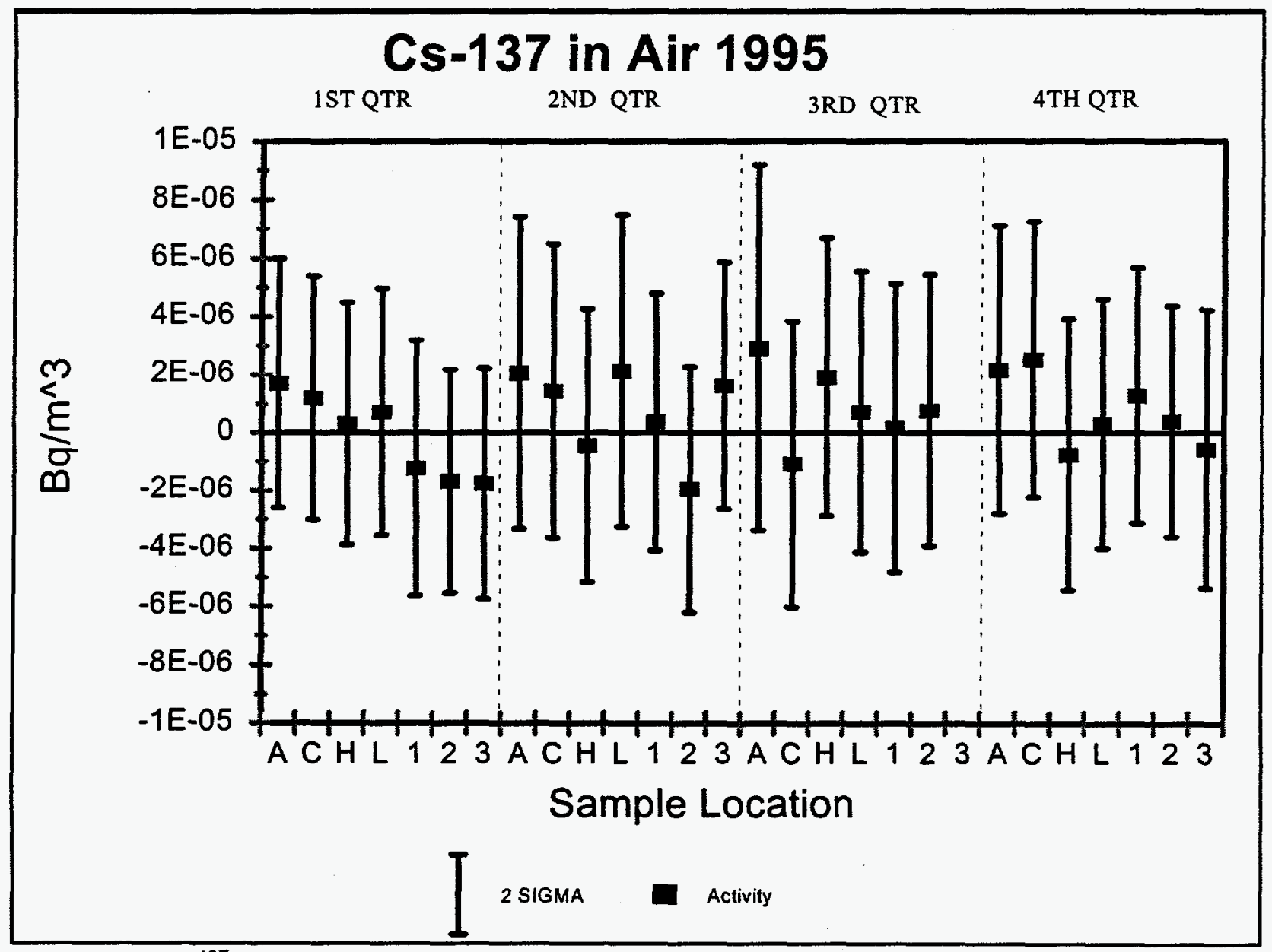

Figure B12. ${ }^{137}$ Cs Concentrations in Air Particulates Collected in 1995 
Table B13. ${ }^{241}$ Am Concentrations in Station A Samples During 1993-1995

\begin{tabular}{|c|c|c|c|c|c|}
\hline $\begin{array}{l}\text { QUARTER } \\
\text { SAMPLE } \\
\text { COLLECTED }\end{array}$ & $\begin{array}{c}\text { SAMPLE } \\
\text { VOLUME } \\
\left(\mathrm{m}^{3}\right)\end{array}$ & $\begin{array}{c}\text { CALCULATED } \\
\text { CONC. } \\
\left(\mathrm{Bg} / \mathrm{m}^{3}\right) \\
\end{array}$ & $\begin{array}{l}{ }^{241} \mathrm{Am} \\
+/-\mathrm{TPU} \\
\left(\mathrm{Bq} / \mathrm{m}^{3}\right)\end{array}$ & $\begin{array}{c}{ }^{241} \mathrm{Am} \\
(+) \\
\left(\mathrm{Bq} / \mathrm{m}^{3}\right)\end{array}$ & $\begin{array}{c}{ }^{241} \mathrm{Am} \\
(-) \\
\left(\mathrm{Bq} / \mathrm{m}^{3}\right) \\
\end{array}$ \\
\hline 1ST 1993 & 5904 & N/A & N/A & N/A & N/A \\
\hline 2ND 1993 & 6412 & $4.4 \mathrm{E}^{-07}$ & $3.1 E^{-07}$ & $1.1 \mathrm{E}^{-06}$ & $-1.7 E^{-07}$ \\
\hline 3RD 1993 & 6595 & $7.1 \mathrm{E}^{-08}$ & $2.2 E^{-07}$ & $5.2 \mathrm{E}^{-07}$ & $-3.7 E^{-07}$ \\
\hline 4TH 1993 & 6619 & $6.9 \mathrm{E}^{-08}$ & $3.0 E^{-07}$ & $6.7 E^{-07}$ & $-5.3 E^{-07}$ \\
\hline 1ST 1994 & 3978 & $4.6 \mathrm{E}^{-08}$ & $3.5 E^{-07}$ & $7.5 \mathrm{E}^{-07}$ & $-6.5 E^{-07}$ \\
\hline 2ND 1994 & 6191 & $1.9 \mathrm{E}^{-08}$ & $2.4 E^{-07}$ & $4.9 \mathrm{E}^{-07}$ & $-4.6 E^{-07}$ \\
\hline 3RD 1994 & 4780 & $2.6 \mathrm{E}^{-07}$ & $3.3 E^{-07}$ & $9.3 E^{-07}$ & $-4.1 \mathrm{E}^{-07}$ \\
\hline 4TH 1994 & 4365 & $6.1 \mathrm{E}^{-08}$ & $3.1 E^{-07}$ & $6.8 \mathrm{E}^{-07}$ & $-5.6 E^{-07}$ \\
\hline 1ST 1995 & 6219 & $-9.8 E^{-08}$ & $1.5 E^{-07}$ & $2.0 \mathrm{E}^{-07}$ & $-3.9 E^{-07}$ \\
\hline 2ND 1995 & 4071 & $1.1 \mathrm{E}^{-07}$ & $2.3 E^{-07}$ & $5.6 \mathrm{E}^{-07}$ & $-3.4 E^{-07}$ \\
\hline 3RD 1995 & 5756 & $-2.1 E^{-08}$ & $1.6 \mathrm{E}^{-07}$ & $3.1 \mathrm{E}^{-07}$ & $-3.5 E^{-07}$ \\
\hline 4TH 1995 & 5595 & $-2.5 E^{-09}$ & $1.6 \mathrm{E}^{-07}$ & $3.3 E^{-07}$ & $-3.3 E^{-07}$ \\
\hline
\end{tabular}




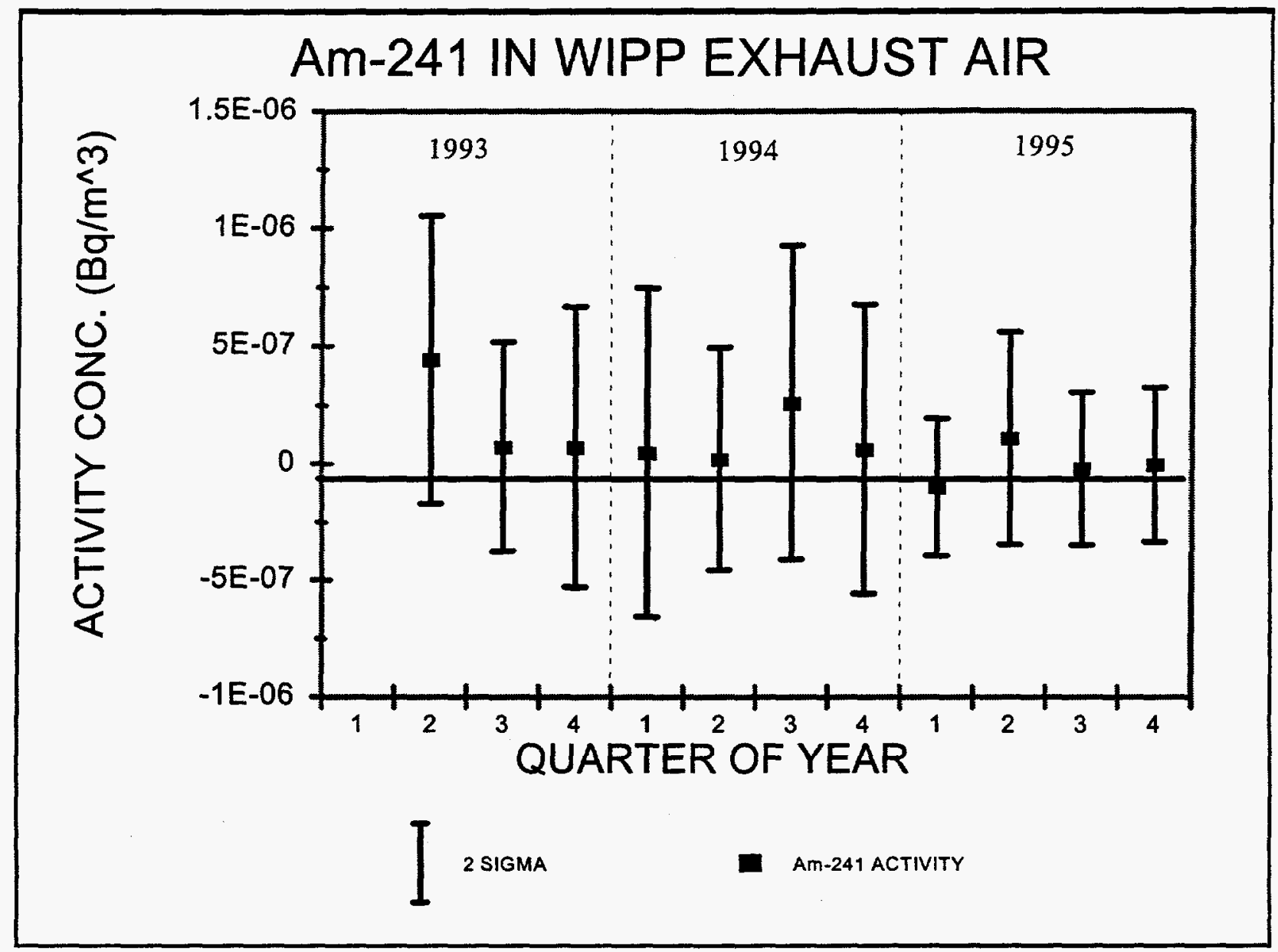

Figure B13. ${ }^{241}$ Am Concentrations in Effluent Air Particulates 1993-1995 
Table B14. ${ }^{239+240} \mathrm{Pu}$ Concentrations in Station A Samples During 1993-1995

\begin{tabular}{|c|c|c|c|c|c|}
\hline $\begin{array}{l}\text { QUARTER } \\
\text { SAMPLE } \\
\text { COLLECTED }\end{array}$ & $\begin{array}{c}\text { SAMPLE } \\
\text { VOLUME } \\
\left(\mathrm{m}^{3}\right)\end{array}$ & $\begin{array}{c}\text { CALCULATED } \\
\text { CONC. } \\
(\mathrm{Bg} / \mathrm{m} 3) \\
\end{array}$ & $\begin{array}{r}{ }^{239+240} \mathrm{Pu} \\
+/-\mathrm{TPU} \\
\left(\mathrm{Bq} / \mathrm{m}^{3}\right) \\
\end{array}$ & $\begin{array}{c}{ }^{239+240} \mathrm{Pu} \\
(+) \\
\left(\mathrm{Bq} / \mathrm{m}^{3}\right)\end{array}$ & $\begin{array}{c}{ }^{239+240} \mathrm{Pu} \\
(-) \\
\left(\mathrm{Bq} / \mathrm{m}^{3}\right)\end{array}$ \\
\hline 1ST 1993 & 5904 & $-3.0 E^{-08}$ & $3.4 E^{-07}$ & $6.5 \mathrm{E}^{-07}$ & $-7.1 E^{-07}$ \\
\hline 2ND 1993 & 6412 & $2.6 \mathrm{E}^{-08}$ & $1.8 \mathrm{E}^{-07}$ & $3.9 E^{-07}$ & $-3.4 E^{-07}$ \\
\hline 3RD 1993 & 6595 & $-1.1 E^{-07}$ & $1.5 \mathrm{E}^{-07}$ & $1.9 \mathrm{E}^{-07}$ & $-4.1 E^{-07}$ \\
\hline 4TH 1993 & 6619 & $4.8 \mathrm{E}^{-08}$ & $1.4 E^{-07}$ & $3.3 E^{-07}$ & $-2.3 E^{-07}$ \\
\hline 1ST 1994 & 3978 & $-2.4 E^{-07}$ & $2.3 \mathrm{E}^{-07}$ & $2.1 E^{-07}$ & $-7.0 E^{-07}$ \\
\hline 2ND 1994 & 6191 & $2.2 \mathrm{E}^{-07}$ & $2.1 E^{-07}$ & $6.5 \mathrm{E}^{-07}$ & $-2.1 E^{-07}$ \\
\hline 3RD 1994 & 4780 & $-3.7 E^{-08}$ & $1.7 \mathrm{E}^{-07}$ & $3.0 E^{-07}$ & $-3.8 E^{-07}$ \\
\hline 4TH 1994 & 4365 & $1.9 E^{-07}$ & $2.2 \mathrm{E}^{-07}$ & $6.2 \mathrm{E}^{-07}$ & $-2.5 E^{-07}$ \\
\hline 1ST 1995 & 6219 & $3.0 \mathrm{E}^{-08}$ & $1.1 \mathrm{E}^{-07}$ & $2.6 \mathrm{E}^{-07}$ & $-2.0 E^{-07}$ \\
\hline 2ND 1995 & 4071 & $-1.5 E^{-08}$ & $1.2 \mathrm{E}^{-07}$ & $2.3 \mathrm{E}^{-07}$ & $-2.6 E^{-07}$ \\
\hline 3RD 1995 & 5756 & $3.3 E^{-08}$ & $1.2 E^{-07}$ & $2.8 \mathrm{E}^{-07}$ & $-2.1 E^{-07}$ \\
\hline 4TH 1995 & 5595 & $4.3 E^{-08}$ & $1.2 \mathrm{E}^{-07}$ & $2.9 \mathrm{E}^{-07}$ & $-2.1 E^{-07}$ \\
\hline
\end{tabular}




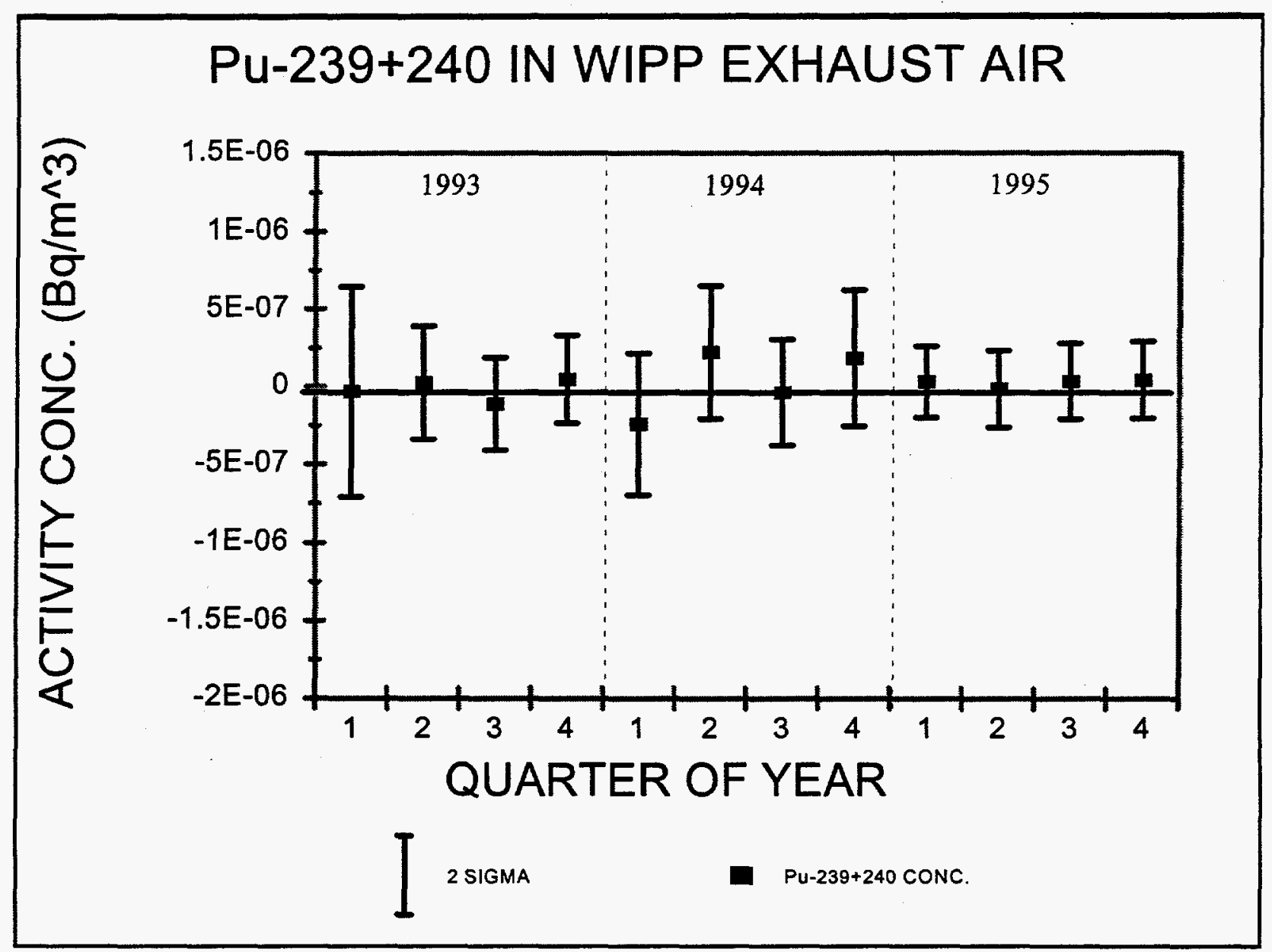

Figure B14. ${ }^{239+240} \mathrm{Pu}$ Concentrations in Effluent Air Particulates 1993-1995 
Table B15. ${ }^{238} \mathrm{Pu}$ Concentrations in Station A Samples During 1993-1995

\begin{tabular}{|c|c|c|c|c|c|}
\hline $\begin{array}{l}\text { QUARTER } \\
\text { SAMPLE } \\
\text { COLLECTED }\end{array}$ & $\begin{array}{c}\text { SAMPLE } \\
\text { VOLUME } \\
\left(\mathrm{m}^{3}\right)\end{array}$ & $\begin{array}{l}\text { CALCULATED } \\
\text { CONC. } \\
\left(\mathrm{Bg} / \mathrm{m}^{3}\right) \\
\end{array}$ & $\begin{array}{c}{ }^{238} \mathrm{Pu} \\
+/-\mathrm{TPU} \\
\left(\mathrm{Bq} / \mathrm{m}^{3}\right)\end{array}$ & $\begin{array}{c}{ }^{238} \mathrm{Pu} \\
(+) \\
\left(\mathrm{Bg} / \mathrm{m}^{3}\right) \\
\end{array}$ & $\begin{array}{c}{ }^{238} \mathrm{Pu} \\
(-) \\
\left(\mathrm{Bg} / \mathrm{m}^{3}\right)\end{array}$ \\
\hline 1ST 1993 & 5904 & N/A & N/A & N/A & N/A \\
\hline 2ND 1993 & 6412 & $8.1 \mathrm{E}^{-08}$ & $1.8 \mathrm{E}^{-07}$ & $4.4 \mathrm{E}^{-07}$ & $-2.8 E^{-07}$ \\
\hline 3RD 1993 & 6595 & $1.6 \mathrm{E}^{-08}$ & $1.4 \mathrm{E}^{-07}$ & $3.0 \mathrm{E}^{-07}$ & $-2.7 E^{-07}$ \\
\hline 4TH 1993 & 6619 & $1.0 \mathrm{E}^{-08}$ & $1.1 E^{-07}$ & $2.3 E^{-07}$ & $-2.0 E^{-07}$ \\
\hline 1ST 1994 & 3978 & $4.5 \mathrm{E}^{-07}$ & $2.9 E^{-07}$ & $1.0 E^{-06}$ & $-1.3 E^{-07}$ \\
\hline 2ND 1994 & 6191 & $3.4 \mathrm{E}^{-08}$ & $1.8 \mathrm{E}^{-07}$ & $3.9 \mathrm{E}^{-07}$ & $-3.2 E^{-07}$ \\
\hline 3RD 1994 & 4780 & $8.6 E^{-08}$ & $2.2 E^{-07}$ & $5.3 E^{-07}$ & $-3.6 E^{-07}$ \\
\hline 4TH 1994 & 4365 & $-1.2 E^{-07}$ & $2.4 E^{-07}$ & $3.6 \mathrm{E}^{-07}$ & $-5.9 E^{-07}$ \\
\hline 1ST 1995 & 6219 & $3.0 E^{-08}$ & $1.1 E^{-07}$ & $2.4 \mathrm{E}^{-07}$ & $-1.8 E^{-07}$ \\
\hline 2ND 1995 & 4071 & $-4.4 E^{-08}$ & $1.1 E^{-07}$ & $1.7 \mathrm{E}^{-07}$ & $-2.6 E^{-07}$ \\
\hline 3RD 1995 & 5756 & $3.3 E^{-08}$ & $1.2 \mathrm{E}^{-07}$ & $2.7 \mathrm{E}^{-07}$ & $-2.1 E^{-07}$ \\
\hline 4TH 1995 & 5595 & $-3.2 E^{-08}$ & $9.6 \mathrm{E}^{-08}$ & $1.6 \mathrm{E}^{-07}$ & $-2.2 E^{-07}$ \\
\hline
\end{tabular}




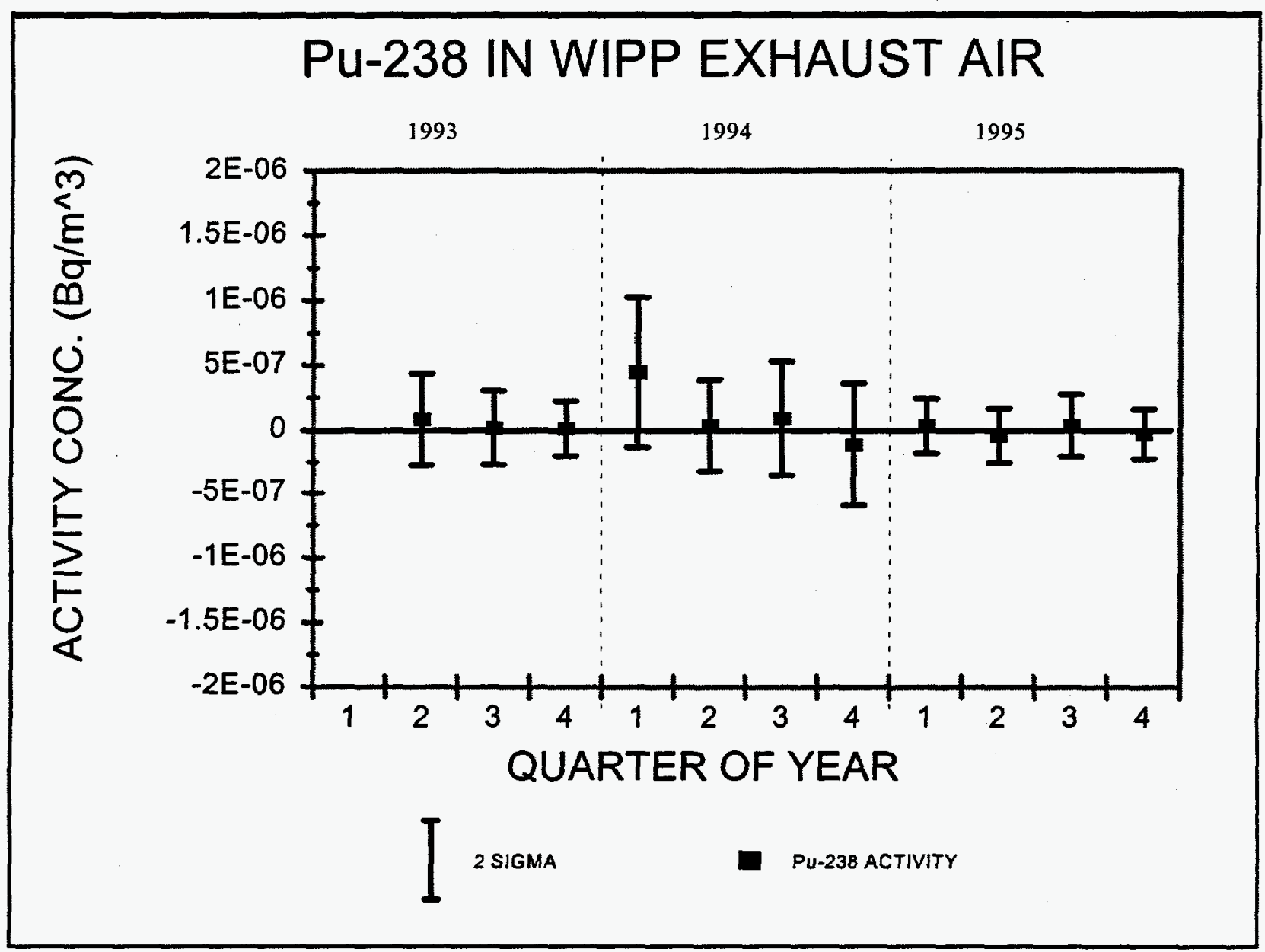

Figure B15. ${ }^{238} \mathrm{Pu}$ Concentrations in Effluent Air Particulates 1993-1995 
Table B16. ${ }^{137}$ Cs Concentrations in Station A Samples During 1993-1995

\begin{tabular}{|c|c|c|c|c|c|}
\hline $\begin{array}{l}\text { QUARTER } \\
\text { SAMPLE } \\
\text { COLLECTED }\end{array}$ & $\begin{array}{c}\text { SAMPLE } \\
\text { VOLUME } \\
\left(\mathrm{m}^{3}\right) \\
\end{array}$ & $\begin{array}{c}\text { CALCULATED } \\
\text { CONC. } \\
\left(\mathrm{Bg} / \mathrm{m}^{3}\right) \\
\end{array}$ & $\begin{array}{c}{ }^{137} \mathrm{Cs} \\
+/-\mathrm{TPU} \\
(\mathrm{Bg} / \mathrm{Comp}) \\
\end{array}$ & $\begin{array}{c}{ }^{137} \mathrm{Cs} \\
(+) \\
\left(\mathrm{Bg} / \mathrm{m}^{3}\right) \\
\end{array}$ & $\begin{array}{c}{ }^{137} \mathrm{Cs} \\
(-) \\
\left(\mathrm{Bq} / \mathrm{m}^{3}\right)\end{array}$ \\
\hline 1ST 1993 & 5904 & $-3.6 E^{-07}$ & $2.0 \mathrm{E}^{-03}$ & $3.9 \mathrm{E}^{-03}$ & $-3.9 E^{-03}$ \\
\hline 2ND 1993 & 6412 & $2.8 \mathrm{E}^{-06}$ & $2.0 E^{-03}$ & $3.9 E^{-03}$ & $-3.9 E^{-03}$ \\
\hline 3RD 1993 & 6595 & $3.5 \mathrm{E}^{-06}$ & $2.0 \mathrm{E}^{-03}$ & $3.9 E^{-03}$ & $-3.9 E^{-03}$ \\
\hline 4TH 1993 & 6619 & $1.3 E^{-06}$ & $2.0 E^{-03}$ & $3.9 \mathrm{E}^{-03}$ & $-3.9 E^{-03}$ \\
\hline 1ST 1994 & 3978 & $6.3 E^{-06}$ & $2.0 E^{-03}$ & $3.9 \mathrm{E}^{-03}$ & $-3.9 E^{-03}$ \\
\hline 2ND 1994 & 6191 & $-6.6 E^{-06}$ & $2.0 E^{-03}$ & $3.9 E^{-03}$ & $-3.9 E^{-03}$ \\
\hline 3RD 1994 & 4780 & $1.5 \mathrm{E}^{-06}$ & $2.0 \mathrm{E}^{-03}$ & $3.9 E^{-03}$ & $-3.9 E^{-03}$ \\
\hline 4TH 1994 & 4365 & $-2.8 E^{-07}$ & $2.0 E^{-03}$ & $3.9 \mathrm{E}^{-03}$ & $-3.9 E^{-03}$ \\
\hline 1ST 1995 & 6219 & $1.5 \mathrm{E}^{-06}$ & $2.0 E^{-03}$ & $3.9 \mathrm{E}^{-03}$ & $-3.9 E^{-03}$ \\
\hline 2ND 1995 & 4071 & $-3.8 E^{-06}$ & $2.0 E^{-03}$ & $3.9 \mathrm{E}^{-03}$ & $-3.9 E^{-03}$ \\
\hline 3RD 1995 & 5756 & $-3.6 E^{-06}$ & $2.0 \mathrm{E}^{-03}$ & $3.9 \mathrm{E}^{-03}$ & $-3.9 E^{-03}$ \\
\hline 4TH 1995 & 5595 & $-3.7 E^{-07}$ & $2.0 E^{-03}$ & $3.9 \mathrm{E}^{-03}$ & $-3.9 E^{-03}$ \\
\hline
\end{tabular}




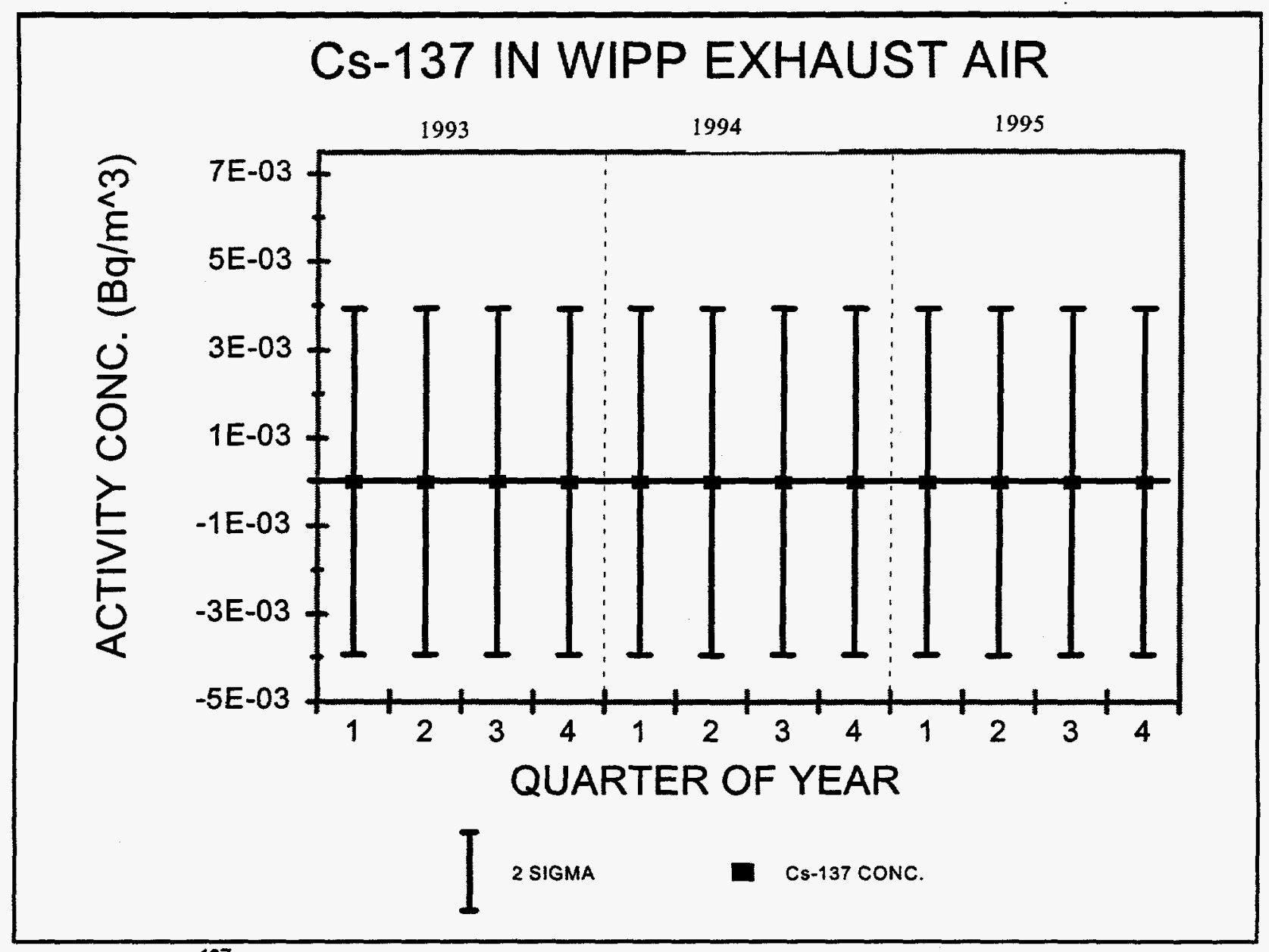

Figure B16. ${ }^{137}$ Cs Concentrations in Effluent Air Particulates 1993-1995 


\section{APPENDIX C}

Note: N/A in the table indicates results not available. The large number of N/A is due to unanticipated analytical problems associated with laboratory start-up 
Table C1. ${ }^{241}$ Am Concentrations in Public Water Systems During 1993-1995

\begin{tabular}{cclcccc}
\hline $\begin{array}{c}\text { SAMPLE } \\
\text { I.D. } \\
\text { CODE }\end{array}$ & $\begin{array}{c}\text { SAMPLE } \\
\text { DATE }\end{array}$ & $\begin{array}{c}\text { SYSTEM } \\
\text { SAMPLED }\end{array}$ & $\begin{array}{c}\text { 241 AM } \\
\text { ACTIVITY } \\
(\mathrm{Bg} / \mathrm{l})\end{array}$ & $\begin{array}{c}\text { TPU } \\
2 \text { SIGMA } \\
(\mathrm{Bq} / \mathrm{l})\end{array}$ & $\begin{array}{c}\text { UPPER } \\
\text { TPU } \\
(\mathrm{Bq} / \mathrm{l})\end{array}$ & $\begin{array}{c}\text { LOWER } \\
\text { TPU } \\
(\mathrm{Bq} / \mathrm{l})\end{array}$ \\
\hline 1 & $11 / 19 / 93$ & OTIS WSS & N/A & N/A & N/A & N/A \\
2 & $11 / 19 / 93$ & LOVING WSS & N/A & N/A & N/A & N/A \\
3 & $11 / 29 / 93$ & WIPP WSS & N/A & N/A & N/A & N/A \\
4 & $06 / 15 / 94$ & LOVING WSS & $-1.27 \mathrm{E}^{-04}$ & $5.30 \mathrm{E}^{-04}$ & $9.32 \mathrm{E}^{-04}$ & $-1.19 \mathrm{E}^{-03}$ \\
5 & $06 / 23 / 94$ & OTIS WSS & $-4.89 \mathrm{E}^{-04}$ & $6.67 \mathrm{E}^{-04}$ & $8.44 \mathrm{E}^{-04}$ & $-1.82 \mathrm{E}^{-03}$ \\
6 & $08 / 16 / 94$ & WIPP WSS & $-3.52 \mathrm{E}^{-04}$ & $4.43 \mathrm{E}^{-04}$ & $5.33 \mathrm{E}^{-04}$ & $-1.24 \mathrm{E}^{-03}$ \\
7 & $10 / 26 / 94$ & CARLSBAD WSS & $2.77 \mathrm{E}^{-04}$ & $5.92 \mathrm{E}^{-04}$ & $1.46 \mathrm{E}^{-03}$ & $-9.08 \mathrm{E}^{-04}$ \\
8 & $03 / 30 / 95$ & WIPP WSS & $1.45 \mathrm{E}^{-04}$ & $5.43 \mathrm{E}^{-04}$ & $1.23 \mathrm{E}^{-03}$ & $-9.41 \mathrm{E}^{-04}$ \\
9 & $04 / 03 / 95$ & OTIS WSS & $6.47 \mathrm{E}^{-04}$ & $6.01 \mathrm{E}^{-04}$ & $1.85 \mathrm{E}^{-03}$ & $-5.55 \mathrm{E}^{-04}$ \\
10 & $04 / 03 / 95$ & LOVING WSS & $8.07 \mathrm{E}^{-04}$ & $2.90 \mathrm{E}^{-04}$ & $1.39 \mathrm{E}^{-03}$ & $2.27 \mathrm{E}^{-04}$ \\
\hline
\end{tabular}




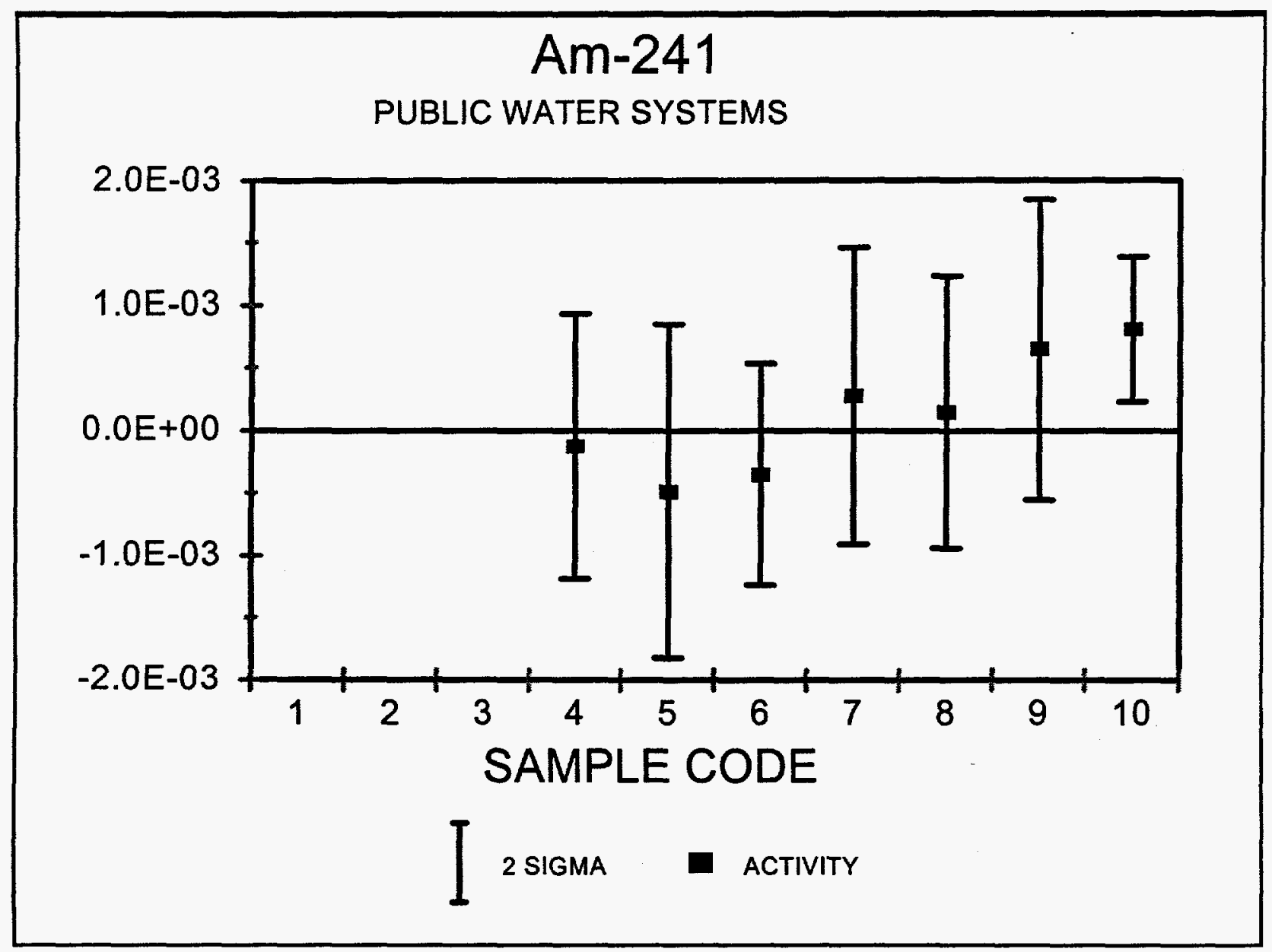

Figure C1. ${ }^{241}$ Am Concentrations in Public Water Systems 1993-1995 
Table C2. ${ }^{239+240} \mathrm{Pu}$ Concentrations in Public Water Systems During 1993-1995

\begin{tabular}{|c|c|c|c|c|c|c|}
\hline $\begin{array}{l}\text { SAMPLE } \\
\text { I.D. } \\
\text { CODE }\end{array}$ & $\begin{array}{l}\text { SAMPLE } \\
\text { DATE }\end{array}$ & $\begin{array}{l}\text { SYSTEM } \\
\text { SAMPLED }\end{array}$ & $\begin{array}{c}{ }^{239+240} \mathrm{PU} \\
\text { ACTIVITY } \\
(\mathrm{Bq} / \mathrm{l})\end{array}$ & $\begin{array}{c}\text { TPU } \\
2 \text { SIGMA } \\
(\mathrm{Bg} / \mathrm{l})\end{array}$ & $\begin{array}{l}\text { UPPER } \\
\text { TPU } \\
(\mathrm{Bg} / \mathrm{l})\end{array}$ & $\begin{array}{l}\text { LOWER } \\
\text { TPU } \\
(\mathrm{Bq} / \mathrm{l})\end{array}$ \\
\hline 1 & $11 / 19 / 93$ & OTIS WSS & $-1.45 \mathrm{E}^{-05}$ & $6.88 \mathrm{E}^{-04}$ & $1.36 \mathrm{E}^{-03}$ & $-1.39 E^{-03}$ \\
\hline 2 & $11 / 19 / 93$ & LOVING WSS & $-2.84 E^{-04}$ & $6.82 \mathrm{E}^{-04}$ & $1.08 \mathrm{E}^{-03}$ & $-1.65 \mathrm{E}^{-03}$ \\
\hline 3 & $11 / 29 / 93$ & WIPP WSS & $2.40 E^{-04}$ & $7.01 E^{-04}$ & $1.64 \mathrm{E}^{-03}$ & $-1.16 E^{-03}$ \\
\hline 4 & $06 / 15 / 94$ & LOVING WSS & $1.65 \mathrm{E}^{-05}$ & $6.80 \mathrm{E}^{-04}$ & $1.38 \mathrm{E}^{-03}$ & $-1.34 E^{-03}$ \\
\hline 5 & $06 / 23 / 94$ & OTIS WSS & $-7.11 \mathrm{E}^{-04}$ & $7.19 \mathrm{E}^{-04}$ & $7.28 \mathrm{E}^{-04}$ & $-2.15 \mathrm{E}^{-03}$ \\
\hline 6 & $08 / 16 / 94$ & WIPP WSS & $-1.58 E^{-04}$ & $6.84 \mathrm{E}^{-04}$ & $1.21 \mathrm{E}^{-03}$ & $-1.53 E^{-03}$ \\
\hline 7 & $10 / 26 / 94$ & CARLSBAD WSS & N/A & N/A & N/A & N/A \\
\hline 8 & 03/30/95 & WIPP WSS & N/A & N/A & N/A & N/A \\
\hline 9 & 04/03/95 & OTIS WSS & $1.90 \mathrm{E}^{-03}$ & $8.64 \mathrm{E}^{-04}$ & $3.63 E^{-03}$ & $1.68 \mathrm{E}^{-04}$ \\
\hline 10 & $04 / 03 / 95$ & LOVING WSS & $4.43 \mathrm{E}^{-04}$ & $6.50 \mathrm{E}^{-04}$ & $1.74 \mathrm{E}^{-03}$ & $-8.57 E^{-04}$ \\
\hline
\end{tabular}




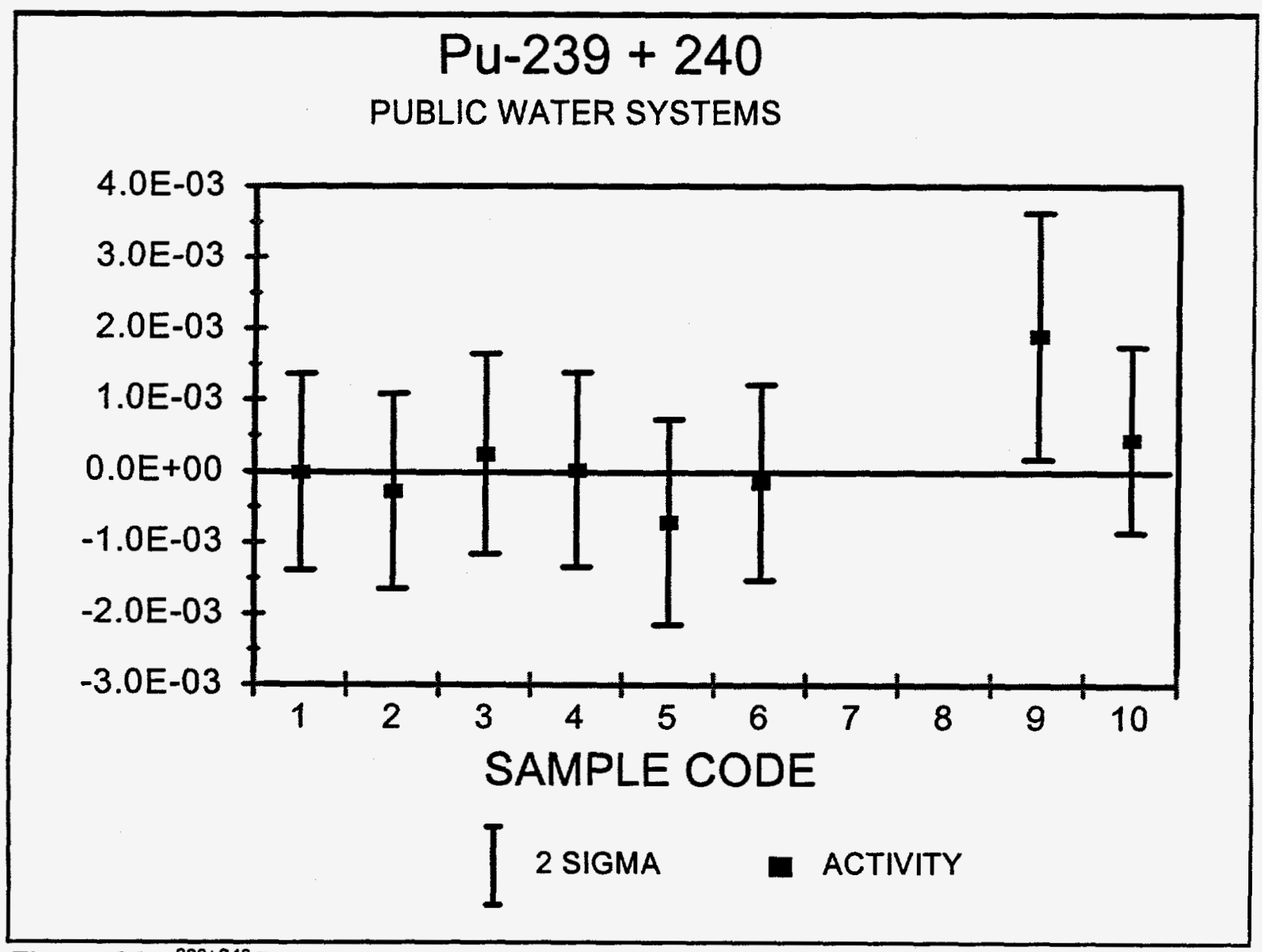

Figure C2. ${ }^{239+240} \mathrm{Pu}$ Concentrations in Public Water Systems 1993-1995 
Table C3. ${ }^{238} \mathrm{Pu}$ Concentrations in Public Water Systems During 1993-1995

\begin{tabular}{cclcccc}
\hline $\begin{array}{c}\text { SAMPLE } \\
\text { I.D. } \\
\text { CODE }\end{array}$ & $\begin{array}{c}\text { SAMPLE } \\
\text { DATE }\end{array}$ & $\begin{array}{c}\text { SYSTEM } \\
\text { SAMPLED }\end{array}$ & $\begin{array}{c}\text { PU-238 } \\
\text { ACTIVITY } \\
(\mathrm{Bq} / \mathrm{l})\end{array}$ & $\begin{array}{c}\text { TPU } \\
2 \text { SIGMA } \\
(\mathrm{Bq} / \mathrm{l})\end{array}$ & $\begin{array}{c}\text { UPPER } \\
\text { TPU } \\
(\mathrm{Bq} / \mathrm{l})\end{array}$ & $\begin{array}{c}\text { LOWER } \\
\text { TPU } \\
(\mathrm{Bq} / \mathrm{l})\end{array}$ \\
\hline 1 & $11 / 19 / 93$ & OTIS WSS & $2.82 \mathrm{E}^{-04}$ & $7.33 \mathrm{E}^{-04}$ & $1.75 \mathrm{E}^{-03}$ & $-1.19 \mathrm{E}^{-03}$ \\
2 & $11 / 19 / 93$ & LOVING WSS & $-8.15 \mathrm{E}^{-06}$ & $6.74 \mathrm{E}^{-04}$ & $1.34 \mathrm{E}^{-03}$ & $-1.36 \mathrm{E}^{-03}$ \\
3 & $11 / 29 / 93$ & WIPP WSS & $-1.52 \mathrm{E}^{-04}$ & $6.91 \mathrm{E}^{-04}$ & $1.23 \mathrm{E}^{-03}$ & $-1.53 \mathrm{E}^{-03}$ \\
4 & $06 / 15 / 94$ & LOVING WSS & $-7.86 \mathrm{E}^{-04}$ & $6.74 \mathrm{E}^{-04}$ & $5.61 \mathrm{E}^{-04}$ & $-2.13 \mathrm{E}^{-03}$ \\
5 & $06 / 23 / 94$ & OTIS WSS & $-5.82 \mathrm{E}^{-05}$ & $8.60 \mathrm{E}^{-04}$ & $1.66 \mathrm{E}^{-03}$ & $-1.78 \mathrm{E}^{-03}$ \\
6 & $08 / 16 / 94$ & WIPP WSS & $1.24 \mathrm{E}^{-04}$ & $6.74 \mathrm{E}^{-04}$ & $1.47 \mathrm{E}^{-03}$ & $-1.22 \mathrm{E}^{-03}$ \\
7 & $10 / 26 / 94$ & CARLSBAD WSS & $-1.02 \mathrm{E}^{-04}$ & $6.99 \mathrm{E}^{-04}$ & $1.30 \mathrm{E}^{-03}$ & $-1.50 \mathrm{E}^{-03}$ \\
8 & $03 / 30 / 95$ & WIPP WSS & $9.98 \mathrm{E}^{-05}$ & $7.26 \mathrm{E}^{-04}$ & $1.55 \mathrm{E}^{-03}$ & $-1.35 \mathrm{E}^{-03}$ \\
9 & $04 / 03 / 95$ & OTIS WSS & $2.20 \mathrm{E}^{-03}$ & $9.05 \mathrm{E}^{-04}$ & $4.01 \mathrm{E}^{-03}$ & $3.93 \mathrm{E}^{-04}$ \\
10 & $04 / 03 / 95$ & LOVING WSS & $-4.52 \mathrm{E}^{-05}$ & $7.13 \mathrm{E}^{-04}$ & $1.38 \mathrm{E}^{-03}$ & $-1.47 \mathrm{E}^{-03}$ \\
\hline
\end{tabular}




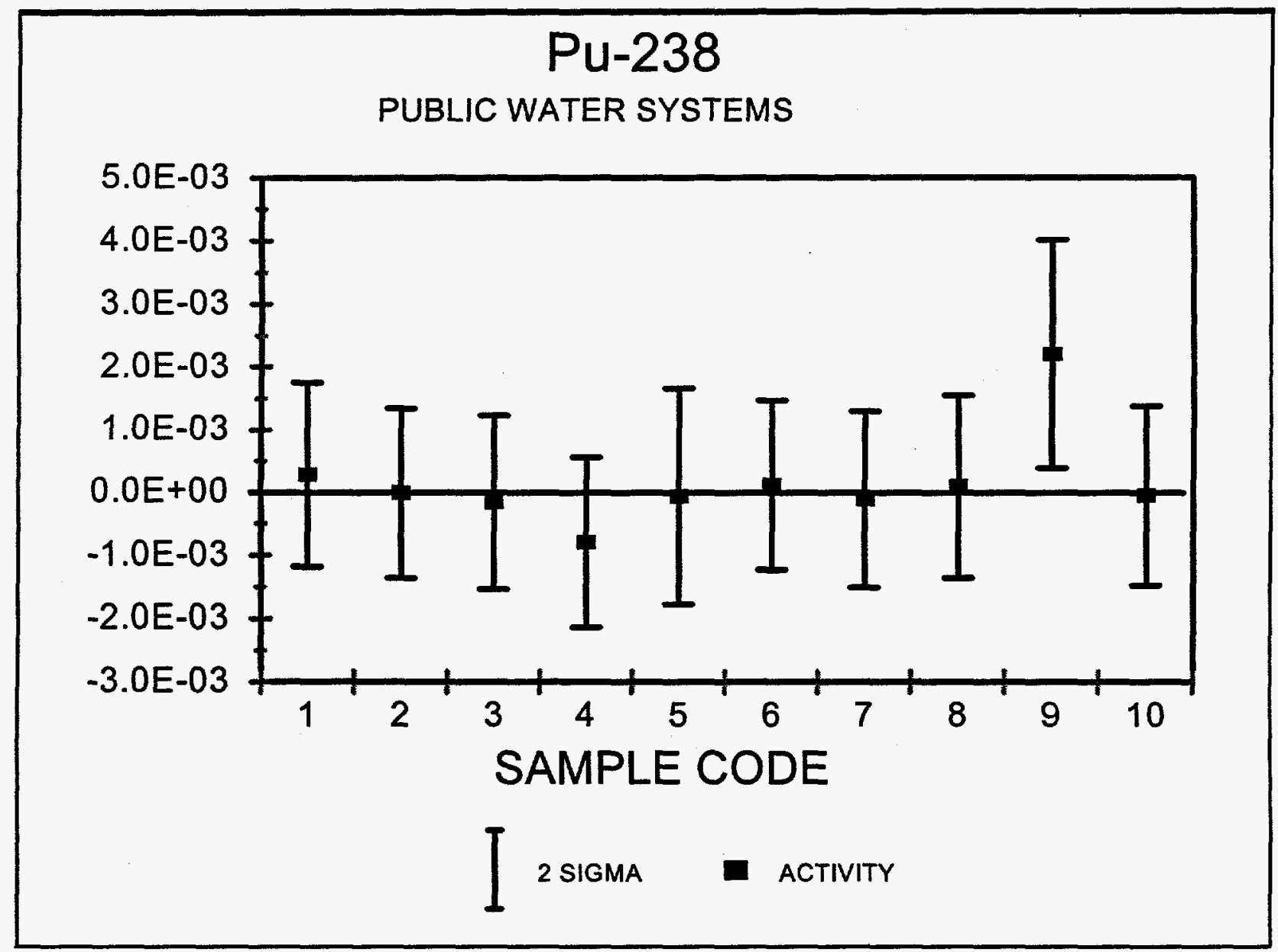

Figure C3. ${ }^{238} \mathrm{Pu}$ Concentrations in Public Water Systems 1993-1995 
Table C4. ${ }^{241}$ Am Concentrations in Surface Water During 1993-1995

\begin{tabular}{|c|c|c|c|c|c|c|}
\hline $\begin{array}{c}\text { SAMPLE } \\
\text { I.D. } \\
\text { CODE } \\
\end{array}$ & $\begin{array}{c}\text { SAMPLE } \\
\text { DATE }\end{array}$ & $\begin{array}{l}\text { LOCATION } \\
\text { SAMPLED }\end{array}$ & $\begin{array}{c}{ }^{241} \mathrm{AM} \\
\mathrm{ACTIVITY} \\
(\mathrm{Bq} / \mathrm{l})\end{array}$ & $\begin{array}{c}\text { TPU } \\
2 \text { SIGMA } \\
(\mathrm{Bq} / 1) \\
\end{array}$ & $\begin{array}{c}\text { UPPER } \\
\text { TPU } \\
(\mathrm{Bq} / \mathrm{l})\end{array}$ & $\begin{array}{c}\text { LOWER } \\
\text { TPU } \\
(\mathrm{Bq} / \mathrm{l})\end{array}$ \\
\hline 1 & $11 / 19 / 93$ & PECOS AT CBD & $-4.13 \mathrm{E}^{-04}$ & $7.72 \mathrm{E}^{-04}$ & $1.13 \mathrm{E}^{-03}$ & $-1.96 \mathrm{E}^{-03}$ \\
\hline 2 & $11 / 19 / 93$ & PECOS AT PIERCE & $-7.83 \mathrm{E}^{-04}$ & $8.91 E^{-04}$ & $9.99 \mathrm{E}^{-04}$ & $-2.57 E^{-03}$ \\
\hline 3 & $11 / 29 / 93$ & NOYE TANK & $N / A$ & $N / A$ & N/A & $N / A$ \\
\hline 4 & $05 / 12 / 94$ & WIPP STORMWATER & $-1.03 E^{-03}$ & $4.29 \mathrm{E}^{-04}$ & $-1.76 \mathrm{E}^{-04}$ & $-1.89 E^{-03}$ \\
\hline 5 & $08 / 25 / 94$ & INDIAN TANK & $2.57 \mathrm{E}^{-04}$ & $5.54 \mathrm{E}^{-04}$ & $1.36 \mathrm{E}^{-03}$ & $-8.51 E^{-04}$ \\
\hline 6 & $08 / 25 / 94$ & HILL TANK & $-3.67 \mathrm{E}^{-04}$ & $4.78 \mathrm{E}^{-04}$ & $5.88 \mathrm{E}^{-04}$ & $-1.32 \mathrm{E}^{-03}$ \\
\hline 7 & $08 / 26 / 94$ & NOYE TANK & $5.77 \mathrm{E}^{-04}$ & $1.07 \mathrm{E}^{-03}$ & $2.72 \mathrm{E}^{-03}$ & $-1.57 E^{-03}$ \\
\hline 8 & $08 / 26 / 94$ & RED TANK & $-8.96 E^{-04}$ & $4.29 \mathrm{E}^{-04}$ & $-3.75 \mathrm{E}^{-05}$ & $-1.76 \mathrm{E}^{-03}$ \\
\hline 9 & $12 / 15 / 94$ & LAGUNA GRANDE & $N / A$ & N/A & N/A & N/A \\
\hline 10 & $12 / 21 / 94$ & PECOS AT CBD & $-9.40 E^{-04}$ & $5.55 \mathrm{E}^{-04}$ & $1.69 \mathrm{E}^{-04}$ & $-2.05 E^{-03}$ \\
\hline 11 & $03 / 29 / 95$ & PECOS AT PIERCE C. & $3.05 \mathrm{E}^{-03}$ & $1.21 \mathrm{E}^{-03}$ & $5.46 \mathrm{E}^{-03}$ & $6.29 \mathrm{E}^{-04}$ \\
\hline 12 & $05 / 15 / 95$ & PECOS AT CBD & $5.37 \mathrm{E}^{-04}$ & $7.90 E^{-04}$ & $2.12 \mathrm{E}^{-03}$ & $-1.04 E^{-03}$ \\
\hline 13 & 06/13/95 & HILL TANK & $2.97 E^{-04}$ & $8.75 \mathrm{E}^{-04}$ & $2.05 \mathrm{E}^{-03}$ & $-1.45 E^{-03}$ \\
\hline 14 & $06 / 13 / 95$ & NOYA TANK & $1.71 \mathrm{E}^{-03}$ & $1.15 \mathrm{E}^{-03}$ & $4.01 \mathrm{E}^{-03}$ & $-5.99 \mathrm{E}^{-04}$ \\
\hline 15 & $09 / 15 / 95$ & WIPP STORMWATER & $-5.34 \mathrm{E}^{-05}$ & $8.48 \mathrm{E}^{-04}$ & $1.64 \mathrm{E}^{.03}$ & $-1.75 E^{-03}$ \\
\hline
\end{tabular}




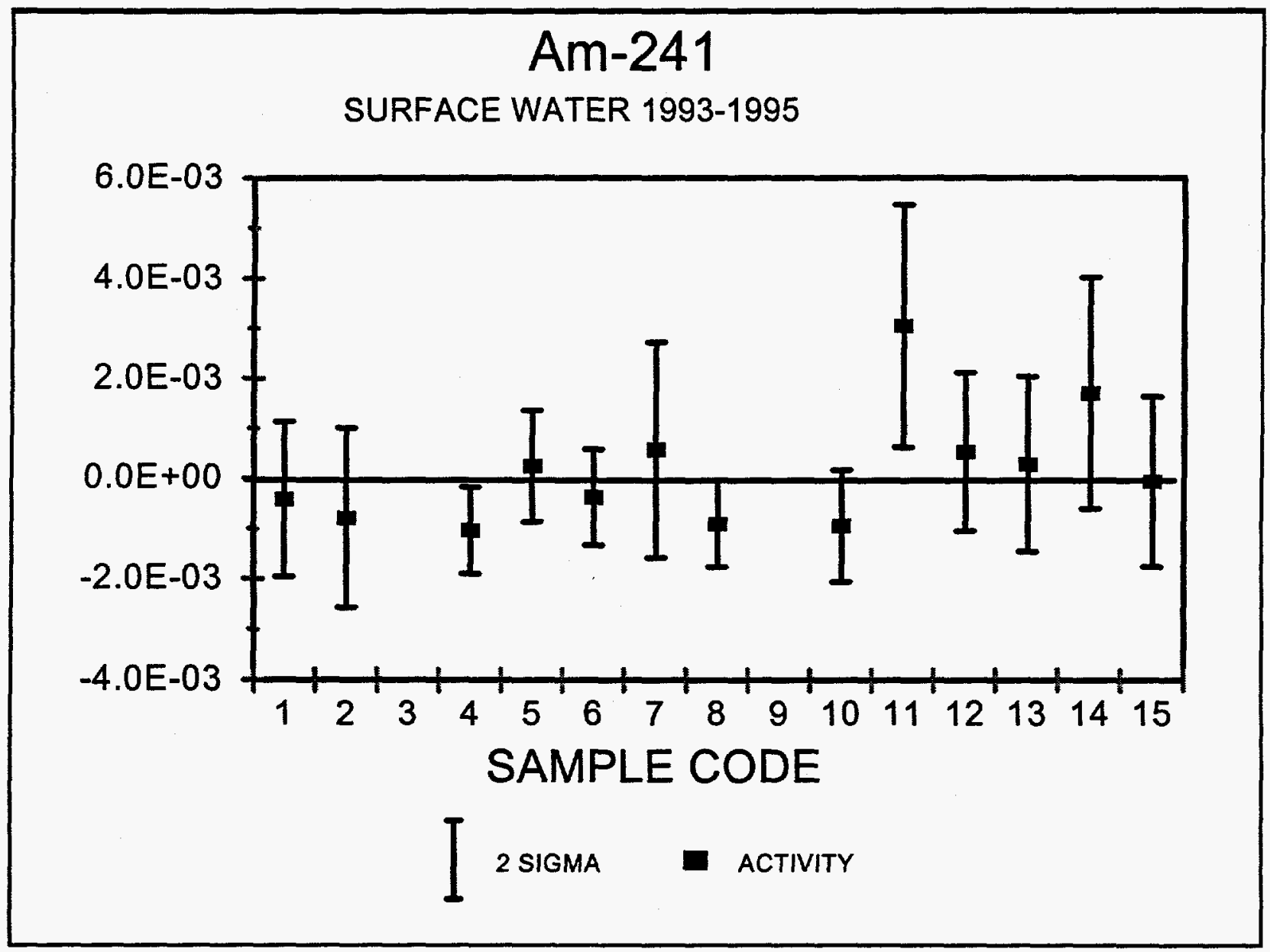

Figure C4. ${ }^{241} \mathrm{Am}$ Concentrations in Surface Water 1993-1995 
Table C5. ${ }^{239+240} \mathrm{Pu}$ Concentrations in Surface Water During 1993-1995

\begin{tabular}{cclcccc}
$\begin{array}{c}\text { SAMPLE } \\
\text { I.D. } \\
\text { CODE }\end{array}$ & $\begin{array}{c}\text { SAMPLE } \\
\text { DATE }\end{array}$ & $\begin{array}{c}\text { LOCATION } \\
\text { SAMPLED }\end{array}$ & $\begin{array}{c}239+240 \\
\text { ACTIVITY } \\
(\mathrm{Bg} / 1)\end{array}$ & $\begin{array}{c}\text { TPU } \\
2 \text { SIGMA } \\
(\mathrm{Bg} / 1)\end{array}$ & $\begin{array}{c}\text { UPPER } \\
\text { TPU } \\
(\mathrm{Bg} / \mathrm{l})\end{array}$ & $\begin{array}{c}\text { LOWER } \\
\text { TPU } \\
(\mathrm{Bq} / \mathrm{l})\end{array}$ \\
\hline 1 & $11 / 19 / 93$ & PECOS AT CBD & $-5.3 \mathrm{E}^{-04}$ & $6.9 \mathrm{E}^{-04}$ & $8.4 \mathrm{E}^{-04}$ & $-1.9 \mathrm{E}^{-03}$ \\
2 & $11 / 19 / 93$ & PECOS AT PIERCE & $-1.7 \mathrm{E}^{-04}$ & $7.1 \mathrm{E}^{-04}$ & $1.2 \mathrm{E}^{-03}$ & $-1.6 \mathrm{E}^{-03}$ \\
3 & $11 / 29 / 93$ & NOYE TANK & $-3.2 \mathrm{E}^{-05}$ & $6.8 \mathrm{E}^{-04}$ & $1.3 \mathrm{E}^{-03}$ & $-1.4 \mathrm{E}^{-03}$ \\
4 & $05 / 12 / 94$ & WIPP STORMWATER & $-3.0 \mathrm{E}^{-04}$ & $6.5 \mathrm{E}^{-04}$ & $1.0 \mathrm{E}^{-03}$ & $-1.6 \mathrm{E}^{-03}$ \\
5 & $08 / 25 / 94$ & INDIAN TANK & $-4.0 \mathrm{E}^{-04}$ & $6.5 \mathrm{E}^{-04}$ & $9.0 \mathrm{E}^{-04}$ & $-1.7 \mathrm{E}^{-03}$ \\
6 & $08 / 25 / 94$ & HILL TANK & $-1.4 \mathrm{E}^{-04}$ & $6.8 \mathrm{E}^{-04}$ & $1.2 \mathrm{E}^{-03}$ & $-1.5 \mathrm{E}^{-03}$ \\
7 & $08 / 26 / 94$ & NOYE TANK & $1.1 \mathrm{E}^{-05}$ & $7.1 \mathrm{E}^{-04}$ & $1.4 \mathrm{E}^{-03}$ & $-1.4 \mathrm{E}^{-03}$ \\
8 & $08 / 26 / 94$ & RED TANK & $-2.2 \mathrm{E}^{-04}$ & $6.5 \mathrm{E}^{-04}$ & $1.1 \mathrm{E}^{-03}$ & $-1.5 \mathrm{E}^{-03}$ \\
9 & $12 / 15 / 94$ & LAGUNA GRANDE & $-4.0 \mathrm{E}^{-04}$ & $6.7 \mathrm{E}^{-04}$ & $9.3 \mathrm{E}^{-04}$ & $-1.7 \mathrm{E}^{-03}$ \\
10 & $12 / 21 / 94$ & PECOS AT CBD & $-7.0 \mathrm{E}^{-05}$ & $7.3 \mathrm{E}^{-04}$ & $1.4 \mathrm{E}^{-03}$ & $-1.5 \mathrm{E}^{-03}$ \\
11 & $03 / 29 / 95$ & PECOS AT PIERCE C. & $-4.0 \mathrm{E}^{-04}$ & $6.5 \mathrm{E}^{-04}$ & $9.0 \mathrm{E}^{-04}$ & $-1.7 \mathrm{E}^{-03}$ \\
12 & $05 / 15 / 95$ & PECOS AT CBD & $-9.2 \mathrm{E}^{-04}$ & $6.5 \mathrm{E}^{-04}$ & $3.8 \mathrm{E}^{-04}$ & $-2.2 \mathrm{E}^{-03}$ \\
13 & $06 / 13 / 95$ & HILL TANK & $-4.0 \mathrm{E}^{-04}$ & $8.6 \mathrm{E}^{-04}$ & $1.3 \mathrm{E}^{-03}$ & $-2.1 \mathrm{E}^{-03}$ \\
14 & $06 / 13 / 95$ & NOYA TANK & $-8.7 \mathrm{E}^{-04}$ & $8.0 \mathrm{E}^{-04}$ & $7.3 \mathrm{E}^{-04}$ & $-2.5 \mathrm{E}^{-03}$ \\
15 & $09 / 15 / 95$ & WIPP STORMWATER & $-9.9 \mathrm{E}^{-04}$ & $7.7 \mathrm{E}^{-04}$ & $5.5 \mathrm{E}^{-04}$ & $-2.5 \mathrm{E}^{-03}$ \\
\hline
\end{tabular}




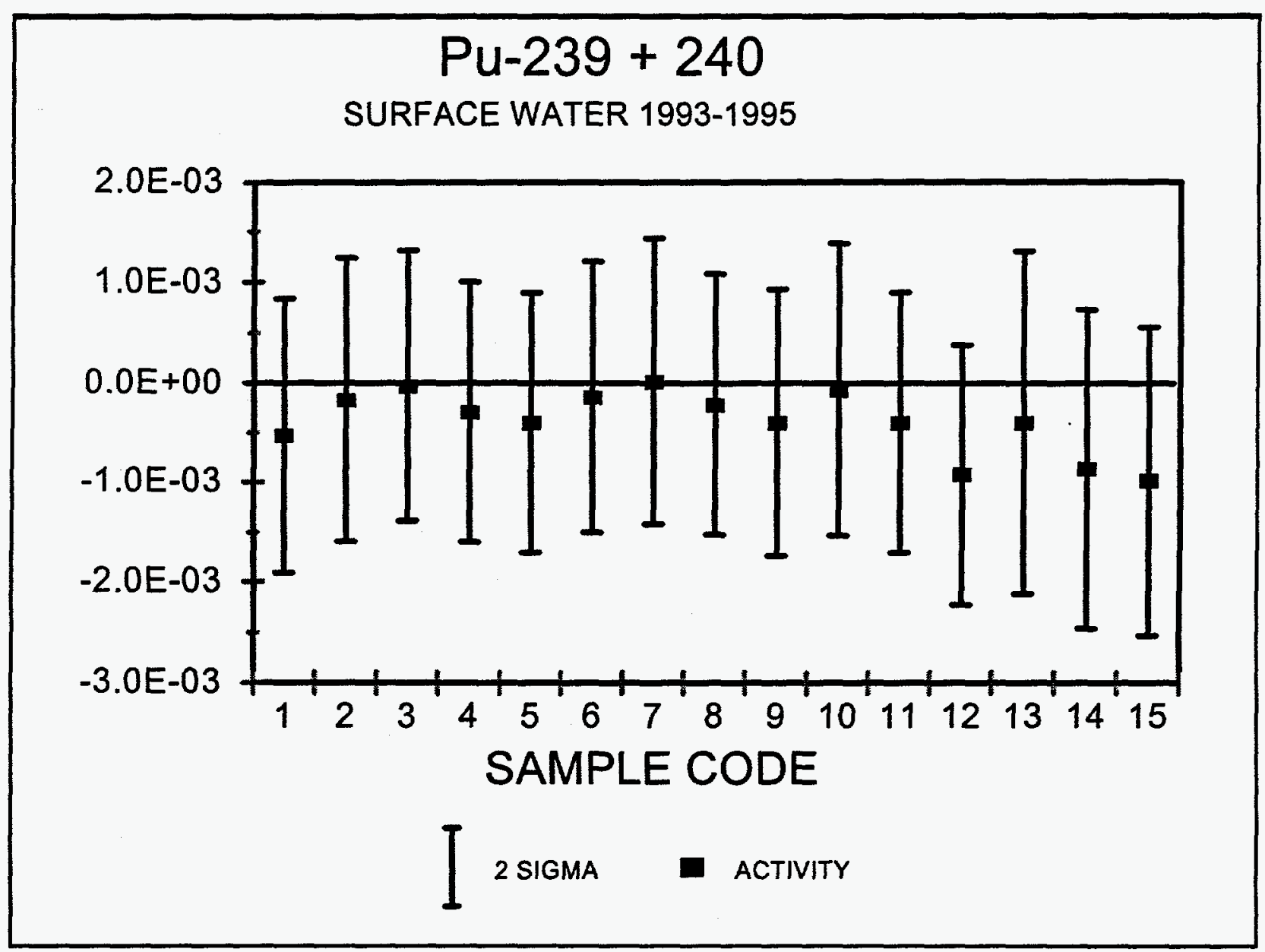

Figure C5. ${ }^{239+240} \mathrm{Pu}$ Concentrations in Surface Water 1993-1995 
Table C6. ${ }^{238} \mathrm{Pu}$ Concentrations in Surface Water During 1993-1995

\begin{tabular}{cclcccc}
\hline $\begin{array}{c}\text { SAMPLE } \\
\text { I.D. } \\
\text { CODE }\end{array}$ & $\begin{array}{c}\text { SAMPLE } \\
\text { DATE }\end{array}$ & $\begin{array}{c}\text { LOCATION } \\
\text { SAMPLED }\end{array}$ & $\begin{array}{c}\text { ACTIVITY } \\
(\mathrm{Bq} / \mathrm{l})\end{array}$ & $\begin{array}{c}\text { TPU } \\
2 \text { SIGMA } \\
(\mathrm{Bq} / \mathrm{l})\end{array}$ & $\begin{array}{c}\text { UPPER } \\
\text { TPU } \\
(\mathrm{Bg} / \mathrm{l})\end{array}$ & $\begin{array}{c}\text { LOWER } \\
\text { TPU } \\
(\mathrm{Bq} / \mathrm{l})\end{array}$ \\
\hline 1 & $11 / 19 / 93$ & PECOS AT CBD & $2.6 \mathrm{E}^{-05}$ & $7.3 \mathrm{E}^{-04}$ & $1.5 \mathrm{E}^{-03}$ & $-1.4 \mathrm{E}^{-03}$ \\
2 & $11 / 19 / 93$ & PECOS AT PIERCE & $-2.2 \mathrm{E}^{-05}$ & $7.0 \mathrm{E}^{-04}$ & $1.4 \mathrm{E}^{-03}$ & $-1.4 \mathrm{E}^{-03}$ \\
3 & $11 / 29 / 93$ & NOYE TANK & $2.8 \mathrm{E}^{-04}$ & $6.8 \mathrm{E}^{-04}$ & $1.6 \mathrm{E}^{-03}$ & $-1.1 \mathrm{E}^{-03}$ \\
4 & $05 / 12 / 94$ & WIPP STORMWATER & $-8.2 \mathrm{E}^{-06}$ & $6.7 \mathrm{E}^{-04}$ & $1.3 \mathrm{E}^{-03}$ & $-1.4 \mathrm{E}^{-03}$ \\
5 & $08 / 25 / 94$ & INDIAN TANK & $-4.6 \mathrm{E}^{-04}$ & $7.0 \mathrm{E}^{-04}$ & $9.3 \mathrm{E}^{-04}$ & $-1.9 \mathrm{E}^{-03}$ \\
6 & $08 / 25 / 94$ & HILL TANK & $-1.5 \mathrm{E}^{-04}$ & $6.7 \mathrm{E}^{-04}$ & $1.2 \mathrm{E}^{-03}$ & $-1.5 \mathrm{E}^{-03}$ \\
7 & $08 / 26 / 94$ & NOYE TANK & $-3.7 \mathrm{E}^{-04}$ & $7.1 \mathrm{E}^{-04}$ & $1.0 \mathrm{E}^{-03}$ & $-1.8 \mathrm{E}^{-03}$ \\
8 & $08 / 26 / 94$ & RED TANK & $2.8 \mathrm{E}^{-04}$ & $6.7 \mathrm{E}^{-04}$ & $1.6 \mathrm{E}^{-03}$ & $-1.1 \mathrm{E}^{-03}$ \\
9 & $12 / 15 / 94$ & LAGUNA GRANDE & $-6.9 \mathrm{E}^{-04}$ & $7.7 \mathrm{E}^{-04}$ & $8.5 \mathrm{E}^{-04}$ & $-2.2 \mathrm{E}^{-03}$ \\
10 & $12 / 21 / 94$ & PECOS AT CBD & $-8.4 \mathrm{E}^{-05}$ & $7.2 \mathrm{E}^{-04}$ & $1.4 \mathrm{E}^{-03}$ & $-1.5 \mathrm{E}^{-03}$ \\
11 & $03 / 29 / 95$ & PECOS AT PIERCE C. & $-7.9 \mathrm{E}^{-04}$ & $9.3 \mathrm{E}^{-04}$ & $1.1 \mathrm{E}^{-03}$ & $-2.7 \mathrm{E}^{-03}$ \\
12 & $05 / 15 / 95$ & PECOS AT CBD & $-5.9 \mathrm{E}^{-04}$ & $6.7 \mathrm{E}^{-04}$ & $7.6 \mathrm{E}^{-04}$ & $-1.9 \mathrm{E}^{-03}$ \\
13 & $06 / 13 / 95$ & HILL TANK & $-1.7 \mathrm{E}^{-05}$ & $9.1 \mathrm{E}^{-04}$ & $1.8 \mathrm{E}^{-03}$ & $-1.8 \mathrm{E}^{-03}$ \\
14 & $06 / 13 / 95$ & NOYA TANK & $-5.0 \mathrm{E}^{-04}$ & $1.3 \mathrm{E}^{-03}$ & $2.1 \mathrm{E}^{-03}$ & $-3.1 \mathrm{E}^{-03}$ \\
15 & $09 / 15 / 95$ & WIPP STORMWATER & $-5.8 \mathrm{E}^{-05}$ & $8.9 \mathrm{E}^{-04}$ & $1.7 \mathrm{E}^{-03}$ & $-1.8 \mathrm{E}^{-03}$ \\
\hline
\end{tabular}




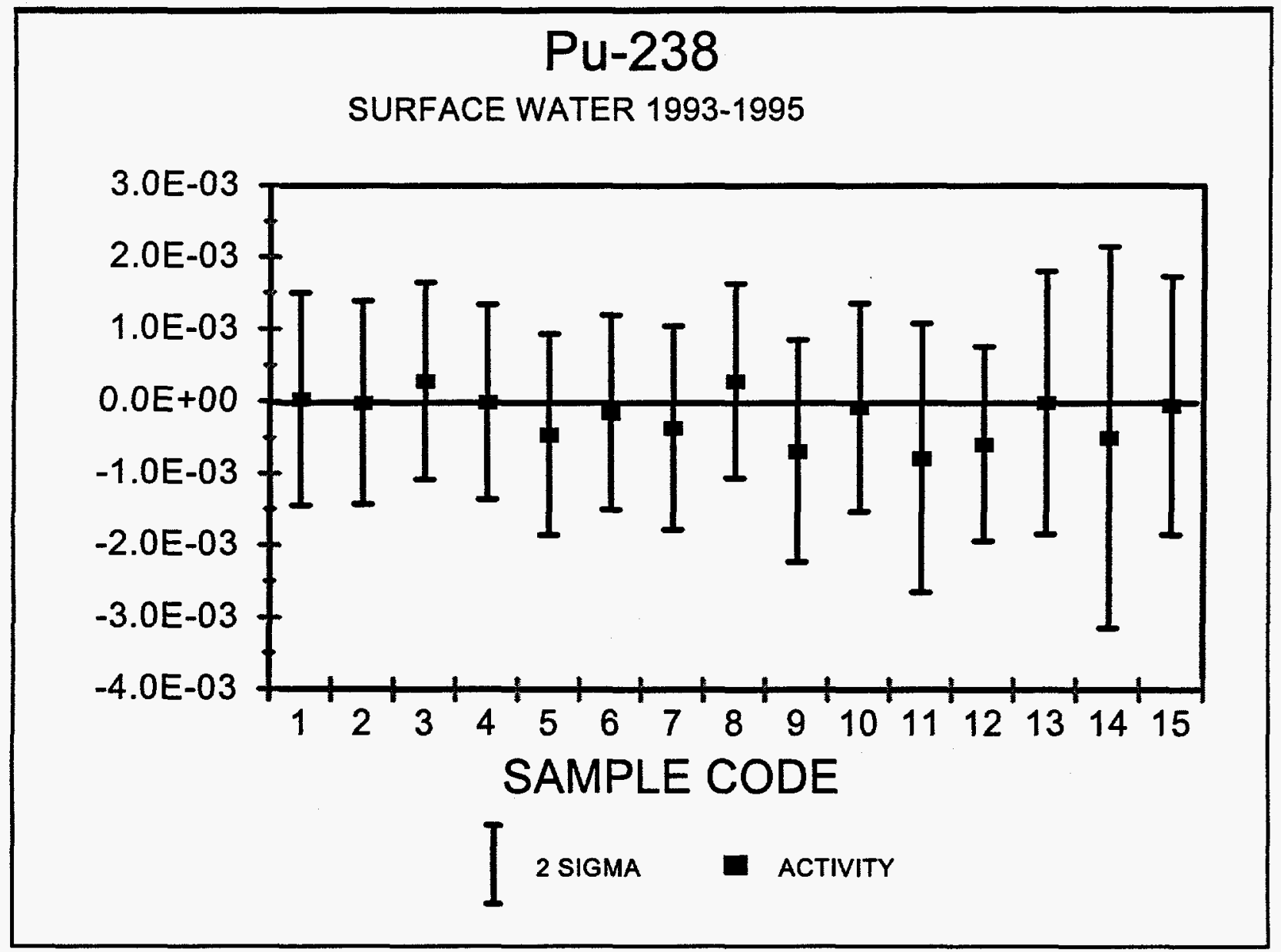

Figure C6. ${ }^{238} \mathrm{Pu}$ Concentrations in Surface Water 1993-1995 
Table C7. ${ }^{241}$ Am Concentrations in Ground Water During 1993-1995

\begin{tabular}{|c|c|c|c|c|c|c|}
\hline $\begin{array}{l}\text { SAMPLE } \\
\text { I.D. } \\
\text { CODE } \\
\end{array}$ & $\begin{array}{c}\text { SAMPLE } \\
\text { DATE }\end{array}$ & $\begin{array}{c}\text { WELL } \\
\text { SAMPLED }\end{array}$ & $\begin{array}{c}{ }^{241} \mathrm{Am} \\
\text { ACTIVITY } \\
(\mathrm{Bg} / \mathrm{l})\end{array}$ & $\begin{array}{c}\text { TPU } \\
2 \text { SIGMA } \\
(\mathrm{Bq} / \mathrm{l}) \\
\end{array}$ & $\begin{array}{c}\text { UPPER } \\
\text { TPU } \\
(\mathrm{Bq} / 1) \\
\end{array}$ & $\begin{array}{c}\text { LOWER } \\
\text { TPU } \\
(\mathrm{Bq} / \mathrm{l})\end{array}$ \\
\hline 1 & $03 / 29 / 94$ & WELL H6B & $-2.8 E^{-04}$ & $5.0 \mathrm{E}^{-04}$ & $7.1 \mathrm{E}^{-04}$ & $-1.3 E^{-03}$ \\
\hline 2 & $04 / 26 / 94$ & WELL H5B & $-4.3 E^{-04}$ & $5.6 \mathrm{E}^{-04}$ & $6.8 \mathrm{E}^{-04}$ & $-1.5 \mathrm{E}^{-03}$ \\
\hline 3 & $05 / 24 / 94$ & WELL WIPP 19 & $-4.4 E^{-04}$ & $4.9 \mathrm{E}^{-04}$ & $5.5 \mathrm{E}^{-04}$ & $-1.4 E^{-03}$ \\
\hline 4 & $06 / 15 / 94$ & RANCH WELL & $-6.7 E^{-04}$ & $5.4 \mathrm{E}^{-04}$ & $4.0 \mathrm{E}^{-04}$ & $-1.8 E^{-03}$ \\
\hline 5 & $06 / 15 / 94$ & BARN WELL & $1.6 \mathrm{E}^{-04}$ & $5.6 \mathrm{E}^{-04}$ & $1.3 \mathrm{E}^{-03}$ & $-9.6 E^{-04}$ \\
\hline 6 & $06 / 21 / 94$ & WELL H2C & $-9.6 \mathrm{E}^{-04}$ & $5.8 \mathrm{E}^{-04}$ & $2.1 \mathrm{E}^{-04}$ & $-2.1 E^{-03}$ \\
\hline 7 & $07 / 19 / 94$ & WELL H3B3 & $-4.0 E^{-04}$ & $8.0 \mathrm{E}^{-04}$ & $1.2 \mathrm{E}^{-03}$ & $-2.0 E^{-03}$ \\
\hline 8 & $08 / 24 / 94$ & WELL USGS 1 & $-2.3 E^{-05}$ & $5.0 \mathrm{E}^{-04}$ & $9.7 \mathrm{E}^{-04}$ & $-1.0 E^{-03}$ \\
\hline 9 & $08 / 30 / 94$ & WELL H11B3 & $-2.5 E^{-04}$ & $1.0 \mathrm{E}^{-03}$ & $1.8 \mathrm{E}^{-03}$ & $-2.3 E^{-03}$ \\
\hline 10 & $09 / 27 / 94$ & WELL H9B & $-8.8 E^{-04}$ & $4.6 \mathrm{E}^{-04}$ & $4.1 E^{-05}$ & $-1.8 E^{-03}$ \\
\hline 11 & $10 / 25 / 94$ & WELL H14 & $7.5 \mathrm{E}^{-04}$ & $6.1 \mathrm{E}^{-04}$ & $2.0 \mathrm{E}^{-03}$ & $-4.7 E^{-04}$ \\
\hline 12 & $11 / 08 / 94$ & WELL H4B & $1.2 E^{-03}$ & $6.3 \mathrm{E}^{-04}$ & $2.4 \mathrm{E}^{-03}$ & $-9.2 E^{-05}$ \\
\hline 13 & $04 / 04 / 95$ & WELL H18 & $8.1 E^{-04}$ & $6.7 \mathrm{E}^{-04}$ & $2.1 E^{-03}$ & $-5.3 E^{-04}$ \\
\hline 14 & $05 / 23 / 95$ & WELL H3B3 & $7.9 \mathrm{E}^{-04}$ & $9.4 \mathrm{E}^{-04}$ & $2.7 E^{-03}$ & $-1.1 E^{-03}$ \\
\hline 15 & $06 / 19 / 95$ & WELL H14 & $-1.1 E^{-03}$ & $8.7 E^{-04}$ & $6.7 E^{-04}$ & $-2.8 E^{-03}$ \\
\hline 16 & $07 / 13 / 95$ & WELL WQSP-6A & N/A & N/A & N/A & N/A \\
\hline 17 & $08 / 17 / 95$ & WELL WQSP-1 & N/A & N/A & N/A & N/A \\
\hline 18 & $10 / 16 / 95$ & WELL WQSP-6 & N/A & N/A & N/A & N/A \\
\hline 19 & $11 / 20 / 95$ & WELL WQSP-5 & N/A & N/A & N/A & N/A \\
\hline
\end{tabular}




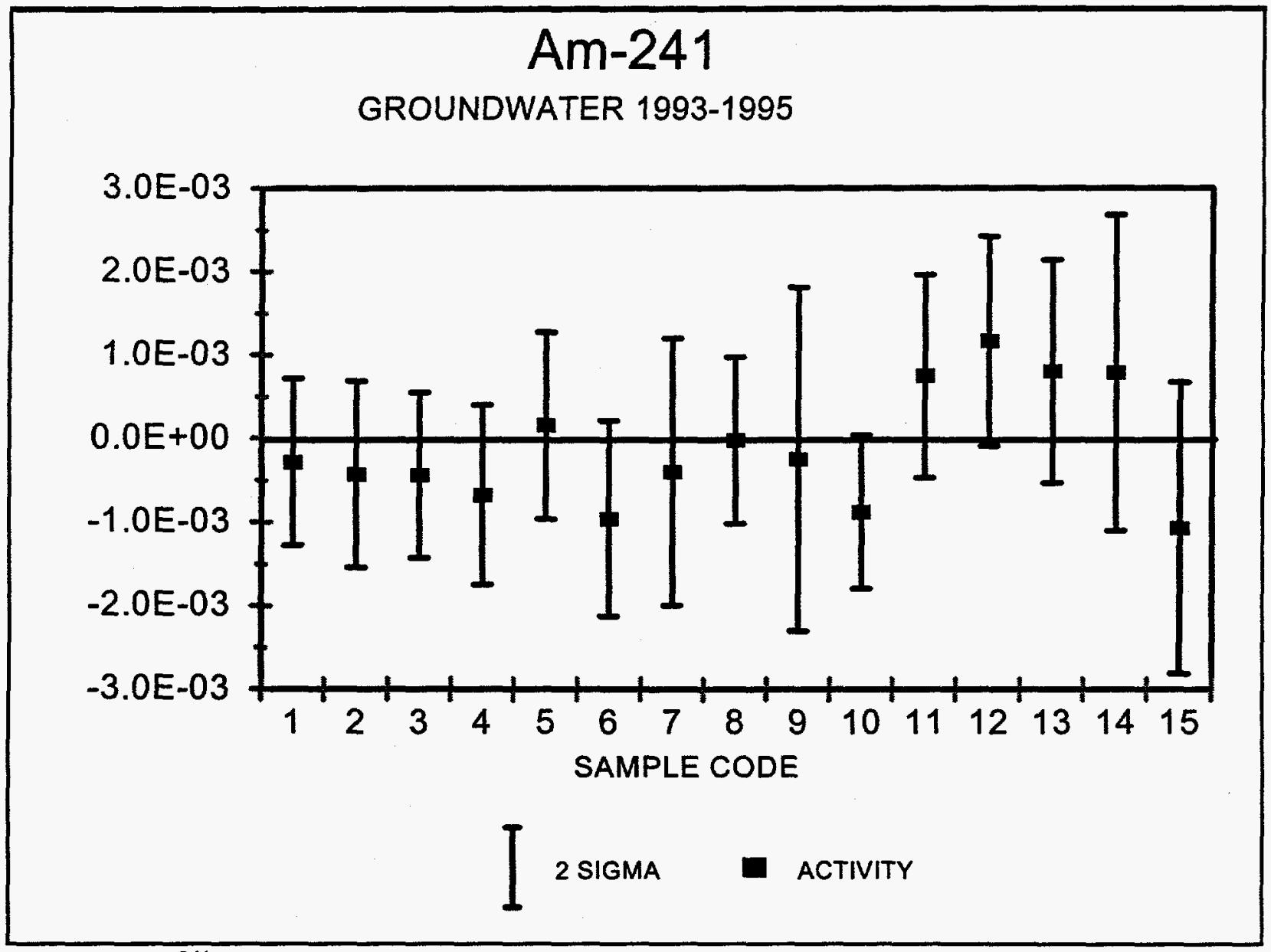

Figure C7. ${ }^{241}$ Am Concentrations in Ground Water 1993-1995 
Table C8. ${ }^{239+240} \mathrm{Pu}$ Concentrations in Ground Water During 1993-1995

\begin{tabular}{|c|c|c|c|c|c|c|}
\hline $\begin{array}{l}\text { SAMPLE } \\
\text { I.D. } \\
\text { CODE } \\
\end{array}$ & $\begin{array}{c}\text { SAMPLE } \\
\text { DATE }\end{array}$ & $\begin{array}{l}\text { WELL } \\
\text { SAMPLED }\end{array}$ & $\begin{array}{c}{ }^{239+240} \mathrm{Pu} \\
\text { ACTIVITY } \\
(\mathrm{Bg} / \mathrm{ll})\end{array}$ & $\begin{array}{c}\text { TPU } \\
2 \text { SIGMA } \\
(\mathrm{Bq} / \mathrm{l})\end{array}$ & $\begin{array}{c}\text { UPPER } \\
\text { TPU } \\
(\mathrm{Bq} / \mathrm{l})\end{array}$ & $\begin{array}{c}\text { LOWER } \\
\text { TPU } \\
(\mathrm{Bg} / \mathrm{l})\end{array}$ \\
\hline 1 & $03 / 29 / 94$ & WELL H6B & $-8.4 E^{-04}$ & $7.3 E^{-04}$ & $6.1 \mathrm{E}^{-04}$ & $-2.3 E^{-03}$ \\
\hline 2 & $04 / 26 / 94$ & WELL H5B & $-7.7 E^{-05}$ & $7.3 E^{-04}$ & $1.4 \mathrm{E}^{-03}$ & $-1.5 E^{-03}$ \\
\hline 3 & $05 / 24 / 94$ & WELL WIPP 19 & $2.0 E^{-05}$ & $6.9 \mathrm{E}^{-04}$ & $1.4 \mathrm{E}^{-03}$ & $-1.4 E^{-03}$ \\
\hline 4 & $06 / 15 / 94$ & RANCH WELL & $-5.1 E^{-04}$ & $6.6 \mathrm{E}^{-04}$ & $8.0 \mathrm{E}^{-04}$ & $-1.8 E^{-03}$ \\
\hline 5 & $06 / 15 / 94$ & BARN WELL & $-6.4 E^{-04}$ & $6.9 \mathrm{E}^{-04}$ & $7.4 \mathrm{E}^{-04}$ & $-2.0 E^{-03}$ \\
\hline 6 & $06 / 21 / 94$ & WELL H2C & $-8.1 E^{-04}$ & $6.9 E^{-04}$ & $5.7 E^{-04}$ & $-2.2 E^{-03}$ \\
\hline 7 & $07 / 19 / 94$ & WELL H3B3 & $1.3 \mathrm{E}^{-04}$ & $1.1 \mathrm{E}^{-03}$ & $2.4 \mathrm{E}^{-03}$ & $-2.1 E^{-03}$ \\
\hline 8 & $08 / 24 / 94$ & WELL USGS 1 & $-4.0 E^{-04}$ & $6.5 \mathrm{E}^{-04}$ & $9.0 \mathrm{E}^{-04}$ & $-1.7 E^{-03}$ \\
\hline 9 & 08/30/94 & WELL H11B3 & $-1.5 E^{-06}$ & $7.7 \mathrm{E}^{-04}$ & $1.5 \mathrm{E}^{-03}$ & $-1.5 E^{-03}$ \\
\hline 10 & $09 / 27 / 94$ & WELL H9B & $-2.7 E^{-04}$ & $6.9 \mathrm{E}^{-04}$ & $1.1 E^{-03}$ & $-1.6 E^{-03}$ \\
\hline 11 & $10 / 25 / 94$ & WELL H14 & $-4.0 E^{-04}$ & $6.5 \mathrm{E}^{-04}$ & $9.0 \mathrm{E}^{-04}$ & $-1.7 E^{-03}$ \\
\hline 12 & $11 / 08 / 94$ & WELL H4B & $-4.0 E^{-04}$ & $6.7 E^{-04}$ & $9.3 \mathrm{E}^{-04}$ & $-1.7 E^{-03}$ \\
\hline 13 & $04 / 04 / 95$ & WELL H18 & $4.4 \mathrm{E}^{-04}$ & $7.4 \mathrm{E}^{-04}$ & $1.9 \mathrm{E}^{-03}$ & $-1.0 E^{-03}$ \\
\hline 14 & $05 / 23 / 95$ & WELL H3B3 & $-5.9 E^{-04}$ & $6.7 E^{-04}$ & $7.6 \mathrm{E}^{-04}$ & $-1.9 E^{-03}$ \\
\hline 15 & 06/19/95 & WELL H14 & $-8.6 E^{-04}$ & $7.9 E^{-04}$ & $7.3 E^{-04}$ & $-2.4 E^{-03}$ \\
\hline 16 & $07 / 13 / 95$ & WELL WQSP-6A & $1.9 E^{-03}$ & $1.5 \mathrm{E}^{-03}$ & $4.9 \mathrm{E}^{-03}$ & $-1.1 E^{-03}$ \\
\hline 17 & $08 / 17 / 95$ & WELL WQSP-1 & $5.2 E^{-04}$ & $9.2 E^{-04}$ & $2.4 \mathrm{E}^{-03}$ & $-1.3 E^{-03}$ \\
\hline 18 & $10 / 16 / 95$ & WELL WQSP-6 & $-1.0 E^{-04}$ & $7.2 \mathrm{E}^{-04}$ & $1.3 \mathrm{E}^{-03}$ & $-1.5 E^{-03}$ \\
\hline 19 & $11 / 20 / 95$ & WELL WQSP-5 & $1.2 \mathrm{E}^{-04}$ & $8.4 \mathrm{E}^{-04}$ & $1.8 \mathrm{E}^{-03}$ & $-1.5 E^{-03}$ \\
\hline
\end{tabular}




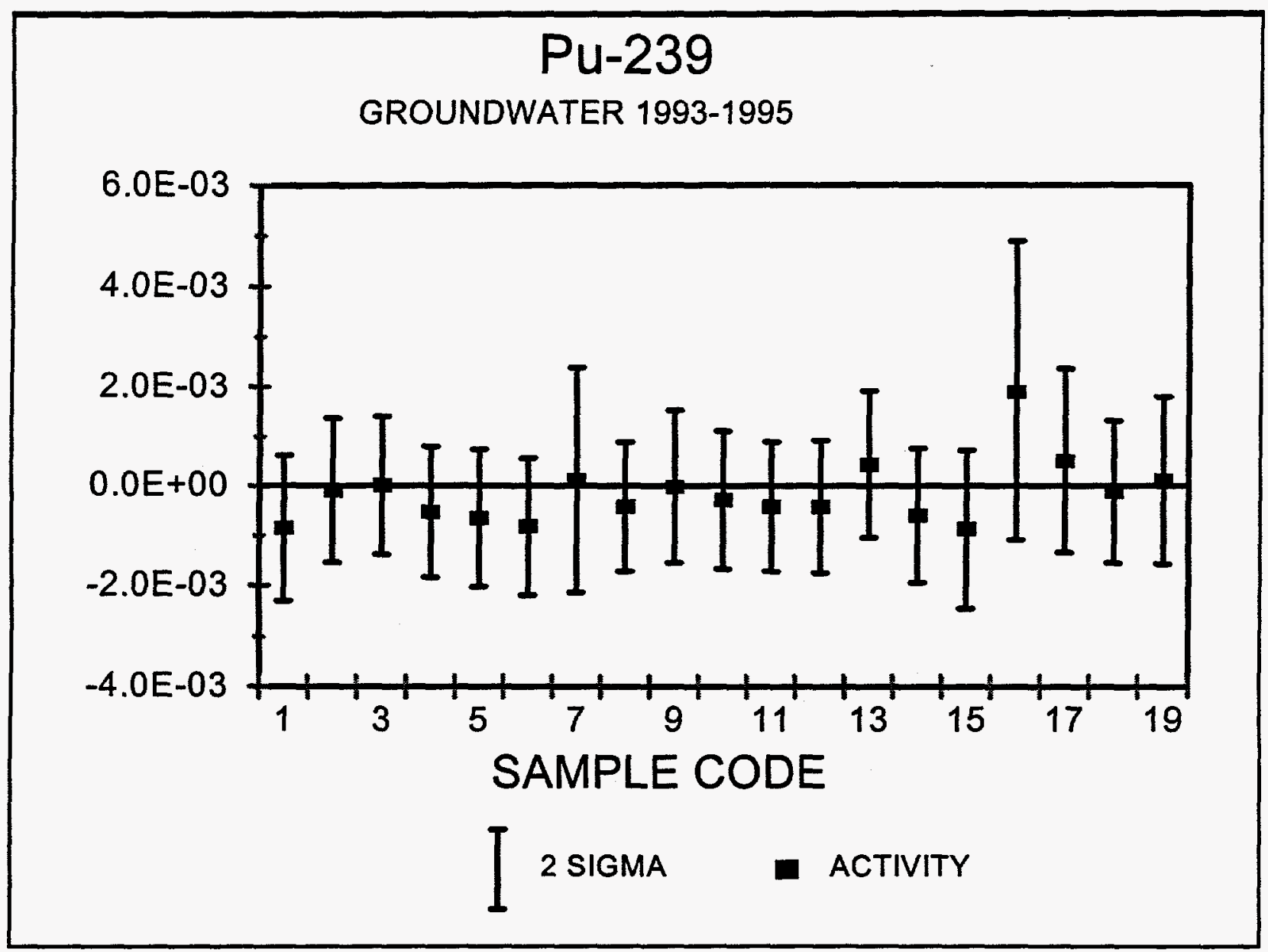

Figure C8. ${ }^{239+240} \mathrm{Pu}$ Concentrations in Ground Water 1993-1995 
Table C9. ${ }^{238} \mathrm{Pu}$ Concentrations in Ground Water During 1993-1995

\begin{tabular}{cclcccc}
\hline $\begin{array}{c}\text { SAMPLE } \\
\text { I.D. } \\
\text { CODE }\end{array}$ & $\begin{array}{c}\text { SAMPLE } \\
\text { DATE }\end{array}$ & $\begin{array}{c}\text { WELL } \\
\text { SAMPLED }\end{array}$ & $\begin{array}{c}\text { ACTIVITY } \\
(\mathrm{Bg} / \mathrm{l})\end{array}$ & $\begin{array}{c}\text { TPU } \\
2 \text { SIGMA } \\
(\mathrm{Bg} / \mathrm{l})\end{array}$ & $\begin{array}{c}\text { UPPER } \\
\text { TPU } \\
(\mathrm{Bg} / \mathrm{l})\end{array}$ & $\begin{array}{c}\text { LOWER } \\
\text { TPU } \\
(\mathrm{Bq} / \mathrm{l})\end{array}$ \\
\hline 1 & $03 / 29 / 94$ & WELL H6B & $-3.7 \mathrm{E}^{-04}$ & $7.3 \mathrm{E}^{-04}$ & $1.1 \mathrm{E}^{-03}$ & $-1.8 \mathrm{E}^{-03}$ \\
2 & $04 / 26 / 94$ & WELL H5B & $2.8 \mathrm{E}^{-04}$ & $7.8 \mathrm{E}^{-04}$ & $1.9 \mathrm{E}^{-03}$ & $-1.3 \mathrm{E}^{-03}$ \\
3 & $05 / 24 / 94$ & WELL WIPP 19 & $-8.4 \mathrm{E}^{-05}$ & $7.0 \mathrm{E}^{-04}$ & $1.3 \mathrm{E}^{-03}$ & $-1.5 \mathrm{E}^{-03}$ \\
4 & $06 / 15 / 94$ & RANCH WELL & $-5.9 \mathrm{E}^{-04}$ & $7.3 \mathrm{E}^{-04}$ & $8.6 \mathrm{E}^{-04}$ & $-2.0 \mathrm{E}^{-03}$ \\
5 & $06 / 15 / 94$ & BARN WELL & $-1.7 \mathrm{E}^{-05}$ & $7.0 \mathrm{E}^{-04}$ & $1.4 \mathrm{E}^{-03}$ & $-1.4 \mathrm{E}^{-03}$ \\
6 & $06 / 21 / 94$ & WELL H2C & $-5.0 \mathrm{E}^{-04}$ & $7.4 \mathrm{E}^{-04}$ & $9.7 \mathrm{E}^{-04}$ & $-2.0 \mathrm{E}^{-03}$ \\
7 & $07 / 19 / 94$ & WELL H3B3 & $6.9 \mathrm{E}^{-04}$ & $1.3 \mathrm{E}^{-03}$ & $3.2 \mathrm{E}^{-03}$ & $-1.8 \mathrm{E}^{-03}$ \\
8 & $08 / 24 / 94$ & WELL USGS 1 & $-1.3 \mathrm{E}^{-05}$ & $7.0 \mathrm{E}^{-04}$ & $1.4 \mathrm{E}^{-03}$ & $-1.4 \mathrm{E}^{-03}$ \\
9 & $08 / 30 / 94$ & WELL H11B3 & $-7.7 \mathrm{E}^{-04}$ & $7.9 \mathrm{E}^{-04}$ & $8.0 \mathrm{E}^{-04}$ & $-2.3 \mathrm{E}^{-03}$ \\
10 & $09 / 27 / 94$ & WELL H9B & $-3.7 \mathrm{E}^{-04}$ & $7.2 \mathrm{E}^{-04}$ & $1.1 \mathrm{E}^{-03}$ & $-1.8 \mathrm{E}^{-03}$ \\
11 & $10 / 25 / 94$ & WELL H14 & $-8.9 \mathrm{E}^{-05}$ & $7.3 \mathrm{E}^{-04}$ & $1.4 \mathrm{E}^{-03}$ & $-1.5 \mathrm{E}^{-03}$ \\
12 & $11 / 08 / 94$ & WELL H4B & $1.2 \mathrm{E}^{-03}$ & $8.7 \mathrm{E}^{-04}$ & $2.9 \mathrm{E}^{-03}$ & $-5.8 \mathrm{E}^{-04}$ \\
13 & $04 / 04 / 95$ & WELL H18 & $3.0 \mathrm{E}^{-03}$ & $9.8 \mathrm{E}^{-04}$ & $5.0 \mathrm{E}^{-03}$ & $1.0 \mathrm{E}^{-03}$ \\
14 & $05 / 23 / 95$ & WELL H3B3 & $1.5 \mathrm{E}^{-03}$ & $1.3 \mathrm{E}^{-03}$ & $4.2 \mathrm{E}^{-03}$ & $-1.1 \mathrm{E}^{-03}$ \\
15 & $06 / 19 / 95$ & WELL H14 & $-1.7 \mathrm{E}^{-03}$ & $1.2 \mathrm{E}^{-03}$ & $7.2 \mathrm{E}^{-04}$ & $-4.2 \mathrm{E}^{-03}$ \\
16 & $07 / 13 / 95$ & WELL WQSP-6A & $-3.7 \mathrm{E}^{-04}$ & $7.8 \mathrm{E}^{-04}$ & $1.2 \mathrm{E}^{-03}$ & $-1.9 \mathrm{E}^{-03}$ \\
17 & $08 / 17 / 95$ & WELL WQSP-1 & $9.5 \mathrm{E}^{-05}$ & $8.2 \mathrm{E}^{-04}$ & $1.7 \mathrm{E}^{-03}$ & $-1.5 \mathrm{E}^{-03}$ \\
18 & $10 / 16 / 95$ & WELL WQSP-6 & $-6.7 \mathrm{E}^{-04}$ & $7.4 \mathrm{E}^{-04}$ & $8.1 \mathrm{E}^{-04}$ & $-2.1 \mathrm{E}^{-03}$ \\
19 & $11 / 20 / 95$ & WELL WQSP-5 & $-8.9 \mathrm{E}^{-04}$ & $8.6 \mathrm{E}^{-04}$ & $8.2 \mathrm{E}^{-04}$ & $-2.6 \mathrm{E}^{-03}$ \\
\hline
\end{tabular}




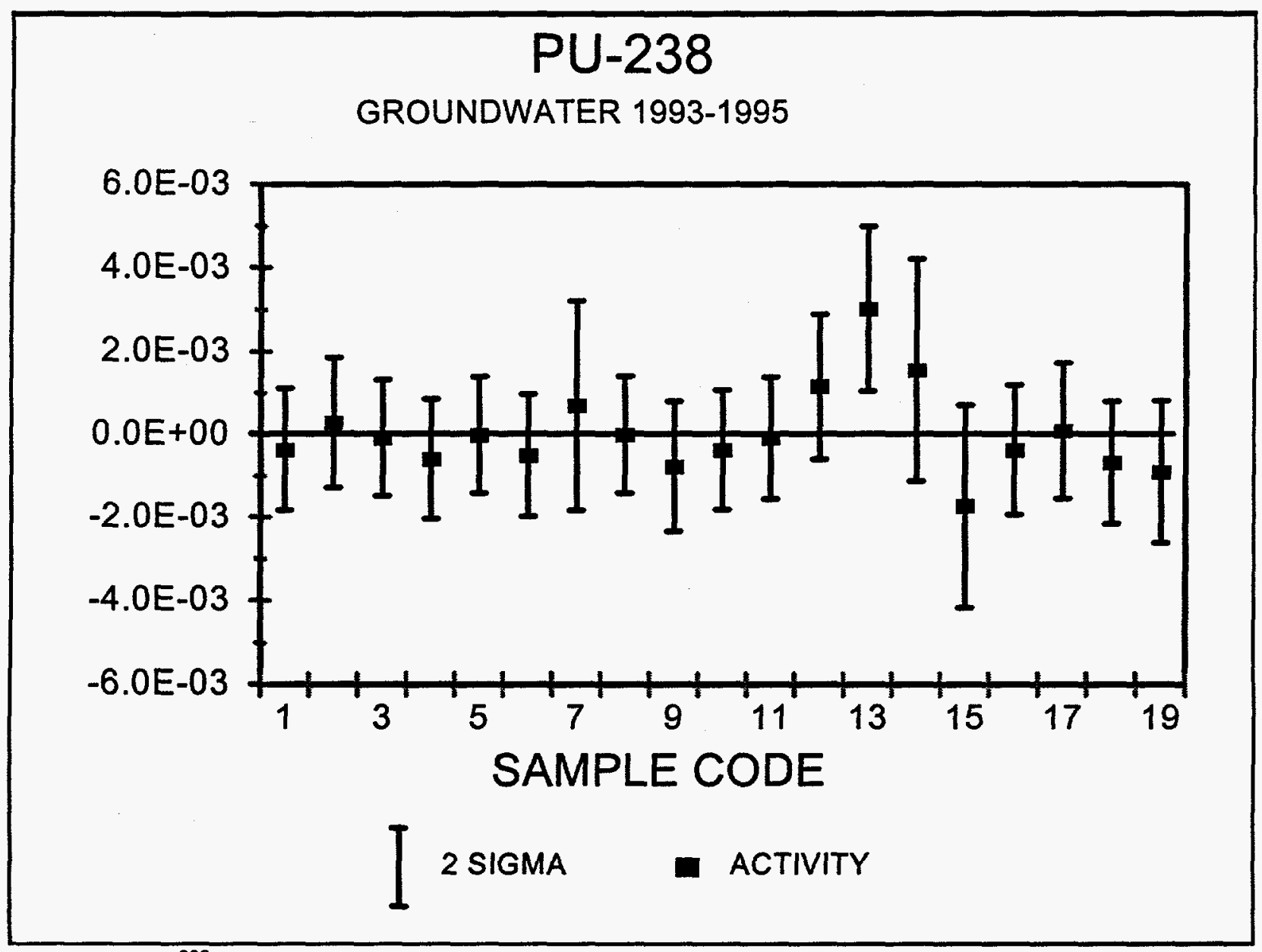

Figure C9. ${ }^{238} \mathrm{Pu}$ Concentrations in Ground Water 1993-1995 


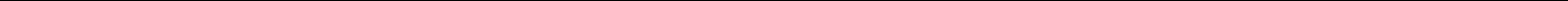


APPENDIX D

MATRIX BLANK DATA 
Table D1. Water Matrix Blank Data

\begin{tabular}{cccc}
\hline $\begin{array}{c}\text { Water Matrix } \\
\text { Blank ID }\end{array}$ & $\begin{array}{c}{ }^{241} \mathrm{Am} \\
(\mathrm{Bq} / \mathrm{l})\end{array}$ & $\begin{array}{c}{ }^{239} \mathrm{Pu} \\
(\mathrm{Bg} / \mathrm{l})\end{array}$ & $\begin{array}{c}{ }^{238} \mathrm{Pu} \\
(\mathrm{Bq} / \mathrm{l})\end{array}$ \\
\hline 940921 & $4.72 \mathrm{E}^{-04}$ & $5.81 \mathrm{E}^{-04}$ & $2.32 \mathrm{E}^{-04}$ \\
940708 & $0.00 \mathrm{E}^{+00}$ & $0.00 \mathrm{E}^{+00}$ & $2.15 \mathrm{E}^{-04}$ \\
950612 & $1.48 \mathrm{E}^{-03}$ & $-3.93 \mathrm{E}^{-04}$ & $-3.93 \mathrm{E}^{-04}$ \\
951116 & $\mathrm{~N} / \mathrm{A}$ & $0.00 \mathrm{E}^{+00}$ & $1.16 \mathrm{E}^{-03}$ \\
960408 & $\mathrm{~N} / \mathrm{A}$ & $9.38 \mathrm{E}^{-04}$ & $-9.38 \mathrm{E}^{-04}$ \\
960801 & $8.11 \mathrm{E}^{-04}$ & $6.92 \mathrm{E}^{-04}$ & $6.92 \mathrm{E}^{-04}$ \\
940817 & $1.28 \mathrm{E}^{-03}$ & $-2.93 \mathrm{E}^{-04}$ & $4.40 \mathrm{E}^{-04}$ \\
970327 & $6.34 \mathrm{E}^{-04}$ & $1.96 \mathrm{E}^{-04}$ & $1.70 \mathrm{E}^{-03}$ \\
970421 & $8.56 \mathrm{E}^{-04}$ & $2.02 \mathrm{E}^{-03}$ & $9.48 \mathrm{E}^{-04}$ \\
970428 & $6.11 \mathrm{E}^{-04}$ & $2.47 \mathrm{E}^{-04}$ & $3.70 \mathrm{E}^{-04}$ \\
970619 & $\mathrm{~N} / \mathrm{A}^{-04}$ & $1.00 \mathrm{E}^{-03}$ & $3.34 \mathrm{E}^{-04}$ \\
970717 & $5.70 \mathrm{E}^{-04}$ & $2.57 \mathrm{E}^{-04}$ & $0.00 \mathrm{E}^{+00}$ \\
970821 & $1.12 \mathrm{E}^{-03}$ & $0.00 \mathrm{E}^{+00}$ & $0.00 \mathrm{E}^{+00}$ \\
\hline AVERAGE $=$ & $7.83 \mathrm{E}^{-04}$ & $4.03 \mathrm{E}^{-04}$ & $3.66 \mathrm{E}^{-04}$ \\
STANDARD & & & \\
DEVIATION $=$ & $4.29 \mathrm{E}^{-04}$ & $6.50 \mathrm{E}^{-04}$ & $6.74 \mathrm{E}^{-04}$ \\
MDA $($ Bq/SAMPLE) $=$ & $2.00 \mathrm{E}^{-03}$ & $3.02 \mathrm{E}^{-03}$ & $3.13 \mathrm{E}^{-03}$ \\
MDC (Bq/I) $=$ & $2.00 \mathrm{E}^{-03}$ & $3.02 \mathrm{E}^{-03}$ & $3.13 \mathrm{E}^{-03}$ \\
\hline
\end{tabular}


Table D2. Station A Matrix Blank Data

\begin{tabular}{|c|c|c|c|c|}
\hline $\begin{array}{c}\text { STATION A } \\
\text { MATRIX BLANK }\end{array}$ & $\begin{array}{c}{ }^{241} \mathrm{Am} \\
(\mathrm{Bq} / \mathrm{COMP})\end{array}$ & $\begin{array}{c}{ }^{239} \mathrm{Pu} \\
(\mathrm{Bg} / \mathrm{COMP})\end{array}$ & $\begin{array}{c}{ }^{238} \mathrm{Pu} \\
(\mathrm{Bq} / \mathrm{COMP})\end{array}$ & $\begin{array}{c}{ }^{137} \mathrm{Cs} \\
(\mathrm{Bq} / \mathrm{COMP})\end{array}$ \\
\hline FMB-960709 & N/A & N/A & N/A & $-7.47 E^{-02}$ \\
\hline FMB-960816 & N/A & N/A & N/A & $-3.25 E^{-02}$ \\
\hline FMB-970910 & $7.7 \mathrm{E}^{-04}$ & $5.3 \mathrm{E}^{-04}$ & $2.0 \mathrm{E}^{-04}$ & $2.78 \mathrm{E}^{-02}$ \\
\hline FMB-A970922 & $4.8 \mathrm{E}^{-04}$ & $1.9 E^{-04}$ & $2.6 \mathrm{E}^{-04}$ & $-4.20 E^{-02}$ \\
\hline FMB-B970922 & $0.0 \mathrm{E}^{+00}$ & $-1.8 \mathrm{E}^{-04}$ & $-3.6 \mathrm{E}^{-04}$ & $6.37 \mathrm{E}^{-02}$ \\
\hline FMB-A971001 & $9.0 E^{-04}$ & $7.5 E^{-04}$ & $4.1 E^{-04}$ & $2.38 \mathrm{E}^{-02}$ \\
\hline FMB-B971001 & $2.2 E^{-04}$ & $6.6 \mathrm{E}^{-05}$ & $1.3 E^{-04}$ & $-4.39 E^{-02}$ \\
\hline FMB-A971008 & $3.6 \mathrm{E}^{-04}$ & $-8.3 E^{-05}$ & $-3.3 E^{-04}$ & $4.06 \mathrm{E}^{-03}$ \\
\hline FMB-B971008 & $3.1 \mathrm{E}^{-04}$ & $6.6 \mathrm{E}^{-05}$ & $1.3 \mathrm{E}^{-04}$ & $3.47 \mathrm{E}^{-02}$ \\
\hline FMB-C971008 & $1.1 \mathrm{E}^{-04}$ & $2.6 \mathrm{E}^{-04}$ & $6.6 \mathrm{E}^{-05}$ & $1.76 \mathrm{E}^{-02}$ \\
\hline FMB-D971008 & $5.8 \mathrm{E}^{-04}$ & $0.0 \mathrm{E}^{+00}$ & $-1.4 E^{-04}$ & $-5.37 E^{-02}$ \\
\hline AVERAGE $=$ & $4.1 E^{-04}$ & $1.8 \mathrm{E}^{-04}$ & $4.2 E^{-05}$ & $-6.8 E^{-03}$ \\
\hline $\begin{array}{l}\text { STANDARD } \\
\text { DEVIATION = }\end{array}$ & $3.0 E^{-04}$ & $3.0 \mathrm{E}^{-04}$ & $2.6 \mathrm{E}^{-04}$ & $4.4 E^{-02}$ \\
\hline$M D A(B q / C O M P)=$ & $1.4 E^{-03}$ & $1.4 E^{-03}$ & $1.2 E^{-03}$ & $2.1 E^{-01}$ \\
\hline$M D C\left(B q / m^{3}\right)=$ & $2.5 E^{-07}$ & $2.5 E^{-07}$ & $2.2 E^{-07}$ & $3.7 E^{-05}$ \\
\hline
\end{tabular}


Table D3. LVAS Matrix Blank Data

\begin{tabular}{ccccc}
\hline $\begin{array}{c}\text { LVAS MATRIX } \\
\text { BLANK ID }\end{array}$ & $\begin{array}{c}{ }^{241} \mathrm{Am} \\
(\mathrm{Bq} / \mathrm{Comp})\end{array}$ & $\begin{array}{c}{ }^{239} \mathrm{Pu} \\
(\mathrm{Bq} / \mathrm{Comp})\end{array}$ & $\begin{array}{c}{ }^{238} \mathrm{Pu} \\
(\mathrm{Bq} / \mathrm{Comp})\end{array}$ & $\begin{array}{c}{ }^{137} \mathrm{Cs} \\
(\mathrm{Bq} / \mathrm{Comp})\end{array}$ \\
\hline $07 / 10 / 95$ & $\mathrm{~N} / \mathrm{A}$ & $\mathrm{N} / \mathrm{A}$ & $\mathrm{N} / \mathrm{A}$ & $-2.10 \mathrm{E}^{-02}$ \\
$12 / 19 / 95$ & $\mathrm{~N} / \mathrm{A}$ & $\mathrm{N} / \mathrm{A}$ & $\mathrm{N} / \mathrm{A}$ & $3.31 \mathrm{E}^{-02}$ \\
$12 / 28 / 95$ & $\mathrm{~N} / \mathrm{A}$ & $\mathrm{N} / \mathrm{A}$ & $\mathrm{N} / \mathrm{A}$ & $3.52 \mathrm{E}^{-03}$ \\
$03 / 15 / 96$ & $\mathrm{~N} / \mathrm{A}$ & $\mathrm{N} / \mathrm{A}$ & $\mathrm{N} / \mathrm{A}$ & $3.96 \mathrm{E}^{-02}$ \\
$02 / 08 / 96$ & $\mathrm{~N} / \mathrm{A}$ & $\mathrm{N} / \mathrm{A}$ & $\mathrm{N} / \mathrm{A}$ & $2.78 \mathrm{E}^{-02}$ \\
$08 / 16 / 96$ & $\mathrm{~N} / \mathrm{A}$ & $\mathrm{N} / \mathrm{A}$ & $\mathrm{N} / \mathrm{A}$ & $1.90 \mathrm{E}^{-03}$ \\
$11 / 04 / 96$ & $4.13 \mathrm{E}^{-04}$ & $3.61 \mathrm{E}^{-04}$ & $5.67 \mathrm{E}^{-04}$ & $-4.04 \mathrm{E}^{-02}$ \\
$11 / 26 / 96$ & $\mathrm{~N} / \mathrm{A}$ & $\mathrm{N} / \mathrm{A}$ & $1.45 \mathrm{E}^{-03}$ & $-4.34 \mathrm{E}^{-02}$ \\
$12 / 11 / 96$ & $7.73 \mathrm{E}^{-05}$ & $\mathrm{~N} / \mathrm{A}$ & $7.45 \mathrm{E}^{-04}$ & $-4.59 \mathrm{E}^{-02}$ \\
$01 / 08 / 97$ & $1.51 \mathrm{E}^{-03}$ & $2.17 \mathrm{E}^{-04}$ & $1.62 \mathrm{E}^{-04}$ & $-3.69 \mathrm{E}^{-02}$ \\
$01 / 29 / 97$ & $6.36 \mathrm{E}^{-04}$ & $1.07 \mathrm{E}^{-04}$ & $-2.13 \mathrm{E}^{-04}$ & $2.09 \mathrm{E}^{-02}$ \\
$02 / 07 / 97$ & $6.08 \mathrm{E}^{-04}$ & $4.13 \mathrm{E}^{-04}$ & $1.03 \mathrm{E}^{-03}$ & $2.83 \mathrm{E}^{-02}$ \\
$04 / 30 / 97$ & $1.05 \mathrm{E}^{-03}$ & $2.82 \mathrm{E}^{-04}$ & $0.00 \mathrm{E}^{+00}$ & $2.55 \mathrm{E}^{-02}$ \\
$06 / 11 / 97$ & $9.56 \mathrm{E}^{-05}$ & $3.99 \mathrm{E}^{-04}$ & $9.58 \mathrm{E}^{-04}$ & $1.87 \mathrm{E}^{-02}$ \\
$07 / 16 / 97$ & $-1.41 \mathrm{E}^{-04}$ & $2.60 \mathrm{E}^{-04}$ & $1.41 \mathrm{E}^{-03}$ & $-4.90 \mathrm{E}^{-02}$ \\
$08 / 08 / 97$ & $5.19 \mathrm{E}^{-04}$ & $-5.60 \mathrm{E}^{-05}$ & $1.18 \mathrm{E}^{-03}$ & $-3.79 \mathrm{E}^{-02}$ \\
\hline AVERAGE = & $5.30 \mathrm{E}^{-04}$ & $2.48 \mathrm{E}^{-04}$ & $7.29 \mathrm{E}^{-04}$ & $-4.70 \mathrm{E}^{-03}$ \\
STANDARD & & & & \\
DEVIATION = & $5.13 \mathrm{E}^{-04}$ & $1.59 \mathrm{E}^{-04}$ & $5.87 \mathrm{E}^{-04}$ & $3.33 \mathrm{E}^{-02}$ \\
MDA(Bq/COMP) = & $2.39 \mathrm{E}^{-03}$ & $7.40 \mathrm{E}^{-04}$ & $2.73 \mathrm{E}^{-03}$ & $1.55 \mathrm{E}^{-01}$ \\
MDC $\left(B q / m^{3}\right)=$ & $9.56 \mathrm{E}^{-08}$ & $2.96 \mathrm{E}^{-08}$ & $1.09 \mathrm{E}^{-07}$ & $6.20 \mathrm{E}^{-08}$ \\
\hline & & & &
\end{tabular}


LIST OF EEG REPORTS 


\section{LIST OF EEG REPORTS}

EEG-1 Goad, Donna, A Compilation of Site Selection Criteria Considerations and Concerns Appearing in the Literature on the Deep Disposal of Radioactive Wastes, June 1979.

EEG-2 Review Comments on Geological Characterization Report, Waste Isolation Pilot Plant (WIPP) Site, Southeastern New Mexico SAND 78-1596, Volume I and II, December 1978.

EEG-3 Neill, Robert H., et al., (eds.) Radiological Health Review of the Draft Environmental Impact Statement (DOE/EIS-0026-D) Waste Isolation Pilot Plant, U.S. Department of Energy, August 1979.

EEG-4 Little, Marshall S., Review Comments on the Report of the Steering Committee on Waste Acceptance Criteria for the Waste Isolation Pilot Plant, February 1980.

EEG-5 Channell, James K., Calculated Radiation Doses From Deposition of Material Released in Hypothetical Transportation Accidents Involving WIPP-Related Radioactive Wastes, October 1980.

EEG-6 Geotechnical Considerations for Radiological Hazard Assessment of WIPP. A Report of a Meeting Held on January 17-18, 1980, April 1980.

EEG-7 Chaturvedi, Lokesh, WIPP Site and Vicinity Geological Field Trip. A Report of a Field Trip to the Proposed Waste Isolation Pilot Plant Project in Southeastern New Mexico, June 16 to 18,1980 , October 1980.

EEG-8 Wofsy, Carla, The Significance of Certain Rustler Aquifer Parameters for Predicting Long-Term Radiation Doses from WIPP, September 1980.

EEG-9 Spiegler, Peter, An Approach to Calculating Upper Bounds on Maximum Individual Doses From the Use of Contaminated Well Water Following a WIPP Repository Breach, September 1981.

EEG-10 Radiological Health Review of the Final Environmental Impact Statement (DOE/EIS0026) Waste Isolation Pilot Plant, U. S. Department of Energy, January 1981.

EEG-11 Channell, James K., Calculated Radiation Doses From Radionuclides Brought to the Surface if Future Drilling Intercepts the WIPP Repository and Pressurized Brine, January 1982.

EEG-12 Little, Marshall S., Potential Release Scenario and Radiological Consequence Evaluation of Mineral Resources at WIPP, May 1982. 


\section{LIST OF EEG REPORTS (CONTINUED)}

EEG-13 Spiegler, Peter, Analysis of the Potential Formation of a Breccia Chimney Beneath the WIPP Repository, May, 1982.

EEG-14 Not published.

EEG-15 Bard, Stephen T., Estimated Radiation Doses Resulting if an Exploratory Borehole Penetrates a Pressurized Brine Reservoir Assumed to Exist Below the WIPP Repository Horizon - A Single Hole Scenario, March 1982.

EEG-16 Radionuclide Release, Transport and Consequence Modeling for WIPP. A Report of a Workshop Held on September 16-17, 1981, February 1982.

EEG-17 Spiegler, Peter, Hydrologic Analyses of Two Brine Encounters in the Vicinity of the Waste Isolation Pilot Plant (WIPP) Site, December 1982.

EEG-18 Spiegler, Peter and Dave Updegraff, Origin of the Brines Near WIPP from the Drill Holes ERDA- 6 and WIPP-12 Based on Stable Isotope Concentration of Hydrogen and Oxygen, March 1983.

EEG-19 Channell, James K., Review Comments on Environmental Analysis Cost Reduction Proposals (WIPP/DOE-136) July 1982, November 1982.

EEG-20 Baca, Thomas E., An Evaluation of the Non-Radiological Environmental Problems Relating to the WIPP, February 1983.

EEG-21 Faith, Stuart, et al., The Geochemistry of Two Pressurized Brines From the Castile Formation in the Vicinity of the Waste Isolation Pilot Plant (WIPP) Site, April 1983.

EEG-22 EEG Review Comments on the Geotechnical Reports Provided by DOE to EEG Under the Stipulated Agreement Through March 1, 1983, April 1983.

EEG-23 Neill, Robert H., et al., Evaluation of the Suitability of the WIPP Site, May 1983.

EEG-24 Neill, Robert H. and James K. Channell, Potential Problems From Shipment of HighCurie Content Contact-Handled Transuranic (CH-TRU) Waste to WIPP, August 1983.

EEG-25 Chaturvedi, Lokesh, Occurrence of Gases in the Salado Formation, March 1984.

EEG-26 Spiegler, Peter, Proposed Preoperational Environmental Monitoring Program for WIPP, November 1984.

EEG-27 Rehfeldt, Kenneth, Sensitivity Analysis of Solute Transport in Fractures and Determination of Anisotropy Within the Culebra Dolomite, September 1984. 


\section{LIST OF EEG REPORTS (CONTINUED)}

EEG-28 Knowles, H. B., Radiation Shielding in the Hot Cell Facility at the Waste Isolation Pilot Plant: A Review, November 1984.

EEG-29 Little, Marshall S., Evaluation of the Safety Analysis Report for the Waste Isolation Pilot Plant Project, May 1985.

EEG-30 Dougherty, Frank, Tenera Corporation, Evaluation of the Waste Isolation Pilot Plant Classification of Systems, Structures and Components, July 1985.

EEG-31 Ramey, Dan, Chemistry of the Rustler Fluids, July 1985.

EEG-32 Chaturvedi, Lokesh and James K. Channell, The Rustler Formation as a Transport Medium for Contaminated Groundwater, December 1985.

EEG-33 Channell, James K., et al., Adequacy of TRUPACT-I Design for Transporting Contact-Handled Transuranic Wastes to WIPP, June 1986.

EEG-34 Chaturvedi, Lokesh, (edi.), The Rustler Formation at the WIPP Site, February 1987.

EEG-35 Chapman, Jenny B., Stable Isotopes in Southeastern New Mexico Groundwater: Implications for Dating Recharge in the WIPP Area, October 1986.

EEG-36 Lowenstein, Tim K., Post Burial Alteration of the Permian Rustler Formation Evaporites, WIPP Site, New Mexico, April 1987.

EEG-37 Rodgers, John C., Exhaust Stack Monitoring Issues at the Waste Isolation Pilot Plant, November 1987.

EEG-38 Rodgers, John C. and Jim W. Kenney, A Critical Assessment of Continuous Air Monitoring Systems at the Waste Isolation Pilot Plant, March 1988.

EEG-39 Chapman, Jenny B., Chemical and Radiochemical Characteristics of Groundwater in the Culebra Dolomite, Southeastern New Mexico, March 1988.

EEG-40 Review of the Final Safety Analyses Report (Draft), DOE Waste Isolation Pilot Plant, December 1988, May 1989.

EEG-41 Review of the Draft Supplement Environmental Impact Statement, DOE Waste Isolation Pilot Plant, July 1989.

EEG-42 Chaturvedi, Lokesh, Evaluation of the DOE Plans for Radioactive Experiments and Operational Demonstration at WIPP, September 1989. 


\section{LIST OF EEG REPORTS (CONTINUED)}

EEG-43 Kenney, Jim W., et al., Preoperational Radiation Surveillance of the WIPP Project by EEG 1985-1988, January 1990.

EEG-44 Greenfield, Moses A., Probabilities of a Catastrophic Waste Hoist Accident at the Waste Isolation Pilot Plant, January 1990.

EEG-45 Silva, Matthew K., Preliminary Investigation into the Explosion Potential of Volatile Organic Compounds in WIPP CH-TRU Waste, June 1990.

EEG-46 Gallegos, Anthony F. and James K. Channell, Risk Analysis of the Transport of Contact Handled Transuranic (CH-TRU) Wastes to WIPP Along Selected Highway Routes in New Mexico Using RADTRAN IV, August 1990.

EEG-47 Kenney, Jim W. and Sally C. Ballard, Preoperational Radiation Surveillance of the WIPP Project by EEG During 1989, December 1990.

EEG-48 Silva, Matthew, An Assessment of the Flammability and Explosion Potential of Transuranic Waste, June 1991.

EEG-49 Kenney, Jim, Preoperational Radiation Surveillance of the WIPP Project by EEG During 1990, November 1991.

EEG-50 Silva, Matthew K. and James K. Channell, Implications of Oil and Gas Leases at the WTPP on Compliance with EPA TRU Waste Disposal Standards, June 1992.

EEG-51 Kenney, Jim W., Preoperational Radiation Surveillance of the WIPP Project by EEG During 1991, October 1992.

EEG-52 Bartlett, William T., An Evaluation of Air Effluent and Workplace Radioactivity Monitoring at the Waste Isolation Pilot Plant, February 1993.

EEG-53 Greenfield, Moses A. and Thomas J. Sargent, A Probabilistic Analysis of a Catastrophic Transuranic Waste Hoist Accident at the WIPP, June 1993.

EEG-54 Kenney, Jim W., Preoperational Radiation Surveillance of the WIPP Project by EEG During 1992, February 1994.

EEG-55 Silva, Matthew K., Implications of the Presence of Petroleum Resources on the Integrity of the WIPP, June 1994.

EEG-56 Silva, Matthew K. and Robert H. Neill, Unresolved Issues for the Disposal of RemoteHandled Transuranic Waste in the Waste isolation Pilot Plant, September 1994. 


\section{LIST OF EEG REPORTS (CONTINUED)}

EEG-57 Lee, William W.-L, Lokesh Chaturvedi, Matthew K. Silva, Ruth Weiner, and Robert H. Neill, An Appraisal of the 1992 Preliminary Performance Assessment for the Waste Isolation Pilot Plant, September 1994.

EEG-58 Kenney, Jim W., Paula S. Downes, Donald H. Gray, Sally C. Ballard, Radionuclide Baseline in Soil Near Project Gnome and the Waste Isolation Pilot Plant, June 1995.

EEG-59 Greenfield, Moses A. and Thomas J. Sargent, An Analysis of the Annual Probability of Failure of the Waste Hoist Brake System at the Waste Isolation Pilot Plant (WIPP), November 1995.

EEG-60 Bartlett, William T. and Ben A. Walker, The Influence of Salt Aerosol an Alpha Radiation Detection by WIPP Continuous Air Monitors, January 1996.

EEG-61 Neill, Robert, Lokesh Chaturvedi, William W.-L. Lee, Thomas M. Clemo, Matthew K. Silva, Jim W. Kenney, William T. Bartlett, and Ben A. Walker, Review of the WIPP Draft Application to Show Compliance with EPA Transuranic Waste Disposal Standards, March 1996.

EEG-62 Silva, Matthew K., Eluid Injection for Salt Water Disposal and Enhanced Oil Recovery as a Potential Problem for the WIPP: Proceedings of a June 1995 Workshop and Analysis, August 1996.

EEG-63 Maleki, Hamid and Lokesh Chaturvedi, Stability Evaluation of the Panel 1 Rooms and the E140 Drift at WIPP, August 1996.

EEG-64 Neill, Robert H., James K. Channell, Peter Spiegler, Lokesh Chaturvedi, Review of the Draft Supplement to the WIPP Environmental Impact Statement, DOE/EIS-0026-S-2, April 1997.

EEG-65 Greenfield, Moses A. and Thomas J. Sargent, Probability of Eailure of the Waste Hoist Brake System at the Waste Isolation Pilot Plant (WIPP), January 1998.

EEG-66 Channell, James K. and Robert H. Neill, Individual Radiation Doses From Transuranic Waste Brought to the Surface by Human Intrusion at the WIPP, February 1998.

EEG-67 Kenney, Jim W., Donald H. Gray, and Sally C. Ballard, Preoperational Radiation Surveillance of the WIPP Project by EEG During 1993 Though 1995, March 1998. 